\title{
An archaeological survey of the Nubra Region (Ladakh, Jammu and Kashmir, India)
}

Prospections archéologiques dans la région de la Nubra (Ladakh, Jammu et Cachemire, Inde)

Quentin Devers, Laurianne Bruneau and Martin Vernier

\section{OpenEdition}

\section{Journals}

Electronic version

URL: https://journals.openedition.org/emscat/2647

DOI: $10.4000 /$ emscat.2647

ISSN: 2101-0013

Publisher

Centre d'Etudes Mongoles \& Sibériennes / École Pratique des Hautes Études

Electronic reference

Quentin Devers, Laurianne Bruneau and Martin Vernier, "An archaeological survey of the Nubra Region (Ladakh, Jammu and Kashmir, India)", Études mongoles et sibériennes, centrasiatiques et tibétaines [Online], 46 | 2015, Online since 10 September 2015, connection on 13 July 2021. URL: http:// journals.openedition.org/emscat/2647 ; DOI: https://doi.org/10.4000/emscat.2647

This text was automatically generated on 13 July 2021

(c) Tous droits réservés 


\title{
An archaeological survey of the Nubra Region (Ladakh, Jammu and Kashmir, India)
}

Prospections archéologiques dans la région de la Nubra (Ladakh, Jammu et Cachemire, Inde)

\author{
Quentin Devers, Laurianne Bruneau and Martin Vernier
}

The authors heartedly thank Anne Chayet, Abram Pointet, Nils Martin, John Vincent Bellezza, Viraf Mehta, Dieter Schuh and John Mock for their academic support and Tsewang Gonbo, Lobsang Stanba, Tsetan Spalzing, Norbu Domkharpa, Phunchok Dorjay, David Sonam and Olivier Tochon for their help in the field.

The authors also wish to thank the following institutions for the funding of fieldwork through grants : École Française d'Extrême Orient (Paris), Fondation Pierre Ledoux-Jeunesse Internationale (Paris), Gerda Henkel Stiftung (Düsseldorf), Association Française des Femmes Diplômées d'Université (Paris), Académie des Inscriptions et Belles-Lettres through the Paule Dumesnil grant (Paris), Indian Cultural Studies (Mumbaï), Fondation Carlo Leone et Mariena Montandon (Sierre), Centre de Recherches Archéologiques Indus-Balouchistan, Asie centrale et orientale (UMR9993,Paris), Centre de Recherche sur les Civilisations de l'Asie Orientale (UMR8155, Paris).

\section{Introduction}

1 The Nubra region, discussed in this paper, is the northernmost of Ladakh and in fact of all of India. It is fed by two main rivers : the Shyok and the Siachen. Both originate from the Siachen glacier, but on either side of the western Karakoram Range. The Siachen river, usually known under the name of Nubra, is the largest tributary of the Shyok, which, in turn, joins the Indus in Baltistan (Pakistan). ${ }^{1}$ The confluence of the Shyok and Nubra rivers is characterised by an open landscape (Fig. 1), where the main villages of the region are found. 
Figure 1. View of the confluence of the Siachen and Shyok rivers from the top tower complex between Sumur and Maral looking southwest

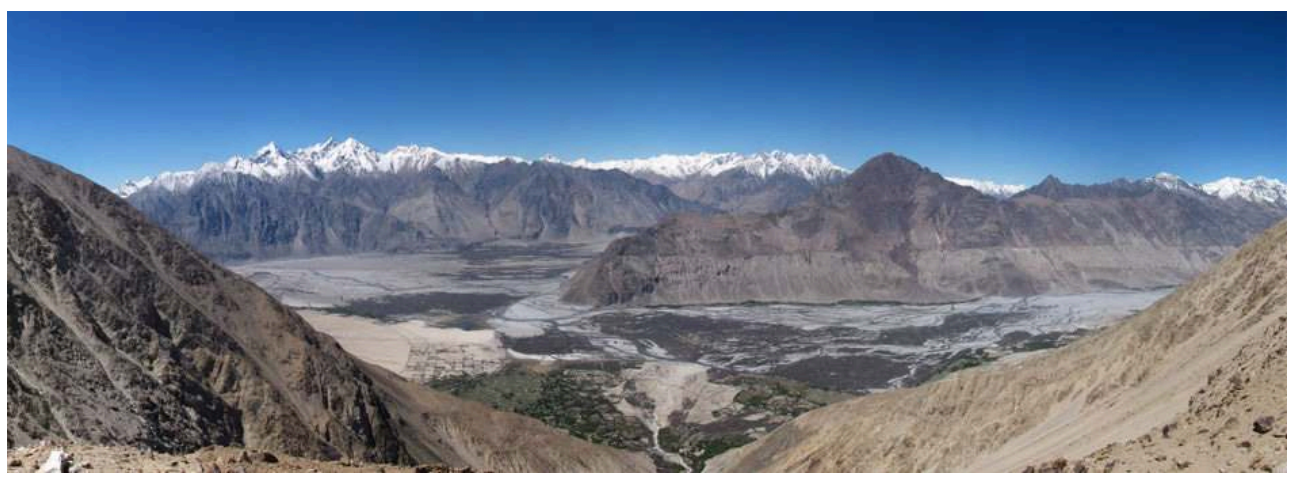

Devers 2011

2 The Nubra region is well known for its role as a gateway between the Indian subcontinent and Central Asia in modern times. It was a trade route between Yarkand (present-day Xinjiang, China) and Leh, the capital of Ladakh, till the closing of borders in 1949. ${ }^{2}$ Besides the Tarim Basin in the north, Nubra is bordered in the south by central Ladakh, in the west by Baltistan and in the east by the Tibetan plateau. A great variety of roads used to link those areas to our region of investigation (Fig. 2).

Figure 2. Routes between Nubra (Central Ladakh and surrounding regions)

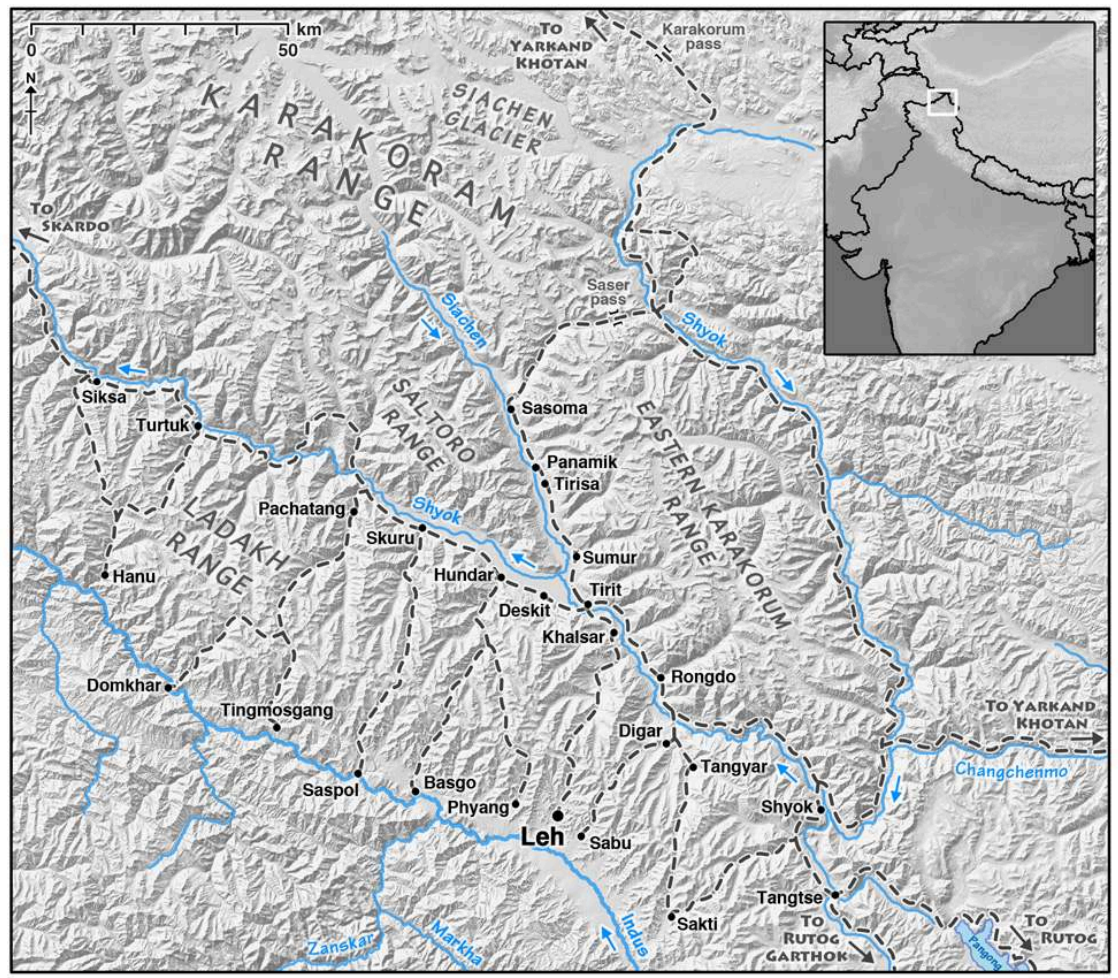

Devers 2014

3 William Moorcroft was the first to explore Nubra in the early 1820s. ${ }^{3}$ Although he mentioned Charasa's fortress he did not provide any description of monuments. A similar remark can be made of the subsequent travelers (surveyors, naturalists, 
political agents, traders, explorers) who passed through the region. Even Aurel Stein, who traveled through the Nubra on his way from Khotan to Leh in 1908, did not mention anything more than the village of Panamik. ${ }^{4}$

The first visitor to Nubra who gave an account of its material culture, and more particularly of its archaeological remains, is August Hermann Francke, a pioneer for archaeological research in Ladakh. As early as 1905 he published hymns and Tibetan inscriptions from Deskit, Hundar and Rongdo handed on to him by an informant. ${ }^{5} \mathrm{He}$ visited Nubra in 1914 on his journey from Khotan to Leh, and mentioned a cave on his way down from the Siachen, as well as an old temple and old chortens (mchod rten) ${ }^{6}$ containing clay tablets (tsha tsha) with Indian script in Khyagar. ${ }^{7}$ That same cave was subsequently visited by the geologist Helmut de Terra in the late 1920 s. ${ }^{8}$ Later, the region being at the core of the Indo-Pakistani political turmoil, no scholarly mention of Nubra was made for almost fifty years.

The opening of a road suitable for motor vehicles in 1969 over the Khardung pass made the region accessible for a new generation of scholars. In 1983, Rohit Vohra conducted fieldwork there and mentioned ruins of fortifications, Buddhist bas-relieves as well as Tibetan stone and temple inscriptions. ${ }^{9}$ These mention local rulers and, together with the manuscript 'history of Deskit monastery' (bde skyid dgon gyi chags rabs), throw light on the history of the valley between the 15th and the 17th century..$^{10}$ The latter document was used, along with others previously unknown, by Zodpa and Shaksgo to compile the first work on the history of Nubra. ${ }^{11}$ Another book was recently published on the history of the region, with a special attention given to sacred landscapes. ${ }^{12}$ The only foreign source referring to Nubra are the memoirs of Mirza Haidar, a TurcoMongol officer who invaded the region from Yarkand in the early 16th century. ${ }^{13}$

6 Prior to the 15th century, the history of Nubra is virtually unknown, and little archaeological research has been conducted in the region until very recently. A first survey took place in 1992, under the direction of R. S. Fonia for the Srinagar Circle of the Archaeological Survey of India. ${ }^{14}$ Thirteen locations were surveyed along the Siachen and Shyok rivers, and the resulting list published referred to a pre-historic cave and site, rock engravings, stone sculptures, temples, monasteries, remains of watchtowers and habitations. Although some dates were proposed, there were no descriptions of the remains. During a second survey, rock-engravings at Tirisa, Murgi and Sasoma were recorded. ${ }^{15}$

7 Over the past ten years, the remains from the Nubra region received unprecedented attention. Preliminary rock art surveys, unfortunately seldom published, were conducted by S. D. Jamwal and T.L. Tshangpa. ${ }^{16}$ The Buddhist carvings of Tirit and Hundar were published as part of a study dedicated to the early Buddhist rock sculptures of Ladakh. ${ }^{17}$ An ongoing research project dedicated to the chortens of Ladakh takes into account those of Ensa and Deskit. ${ }^{18}$ Besides these case studies, an inventory of the cultural heritage of Nubra was published by the Namgyal Institute for Research on Ladakhi Art and Culture (NIRLAC), focusing mainly on thato (lha tho, a small construction housing a protective spirit), mani walls (bearing stones inscribed with mantras), chortens, temples, monasteries, mosques and palatial remains ${ }^{19}$ Another book was recently dedicated to the monasteries of the region. ${ }^{20}$

8 Although some archaeological sites are mentioned in these publications, no comprehensive account has yet been attempted : it is the aim of this paper to do so. The work presented here is the result of extensive surveys conducted by the authors (L. 
Bruneau, Q. Devers and M. Vernier) between 2006 and 2014 (six campaigns), which revealed extremely valuable sites, many previously unreported. They bring to light, among others, long-sought Protohistorical funerary sites, the largest and most important Bronze Age rock art site of Ladakh as well as new evidence of architectural contacts with Central Asia.

The sites are described hereafter according to a geographical order : we begin at Sumur and go up the Siachen river, on its left bank, before reaching its right bank and follow it southwards to Charasa. Then we go down the Shyok river, starting in Digar, then on its right bank from Rongdo to Tirit, and finally on its left bank from Deskit all the way to Turtuk (Fig. 3).

Figure 3. Maps of the main archaeological sites surveyed along the Siachen river between Sumur and Panamik, and along the Shyok river between Tirit and Udmaru

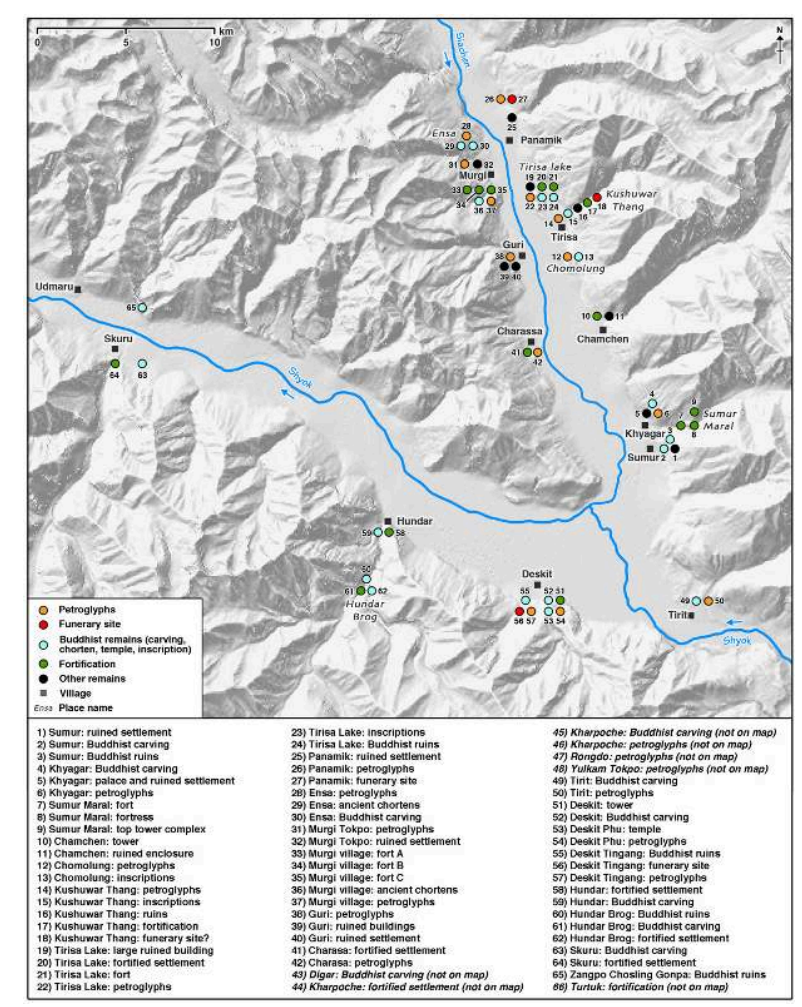

Devers 2014

In the absence of dating, the authors hypothesize the antiquity of the sites and remains presented below whenever sufficient data is available. The sites and their possible chronological framework are listed in Annex 1. A provisional chronology, for the Nubra region only, may be proposed as follows : the term Protohistory is used for the period anterior to the 8th century AD. It may be subdivided into the Bronze and Iron ages that are referring to, respectively, the second millennium $\mathrm{BC}$ and the first millennia $\mathrm{BC}$ and $\mathrm{AD}$ (up to the 8th century). The historic period in the Nubra may start in the 8th century AD, when Buddhism was possibly introduced into the region. This period may be subdivided into 'early history' (8th-13th centuries AD) and 'late history' (from the 14th century onwards). This chronology may be subject to considerable changes in the years to come according to subsequent discoveries and further researches. 


\section{Sumur}

11 Along the Siachen river are the villages of Sumur and Khyagar, located respectively on the left and right side of a lateral stream. The villages are well known for the rather recent but imposing monastery of Samstanling, usually said to be in Sumur but actually built on Khyagar's side of the stream.

\section{Ancient ruined settlement}

From Sumur village, a link road leads to the monastery. Following it, one reaches the stream in the upper part of the village, in the vicinity of the monastic compound. At the mouth of the side valley, on the left bank, are the ruins of an ancient settlement in the mountain slope above the road.

13 The settlement is made of two parts : one consists in dwellings, the other in enclosures, likely for cattle. The habitations are built on small terraces (2-3 in average) set between boulders, and integrate the latter into their walls. Some walls appear to be in dry stone while some display weathered mortar. In a general way, the walls are curvy : only a few are straight with perpendicular angles. The overall characteristics of these habitations (small windowless rooms, random-rubble slab-walls, topographical integration into the parent formation) fit the category of archaic buildings described by Bellezza for Upper Tibet. ${ }^{21}$ Ceramic on the ground is rather abundant, among which we noticed one shard with red paint. The southern edge of the settlement is marked by a thalweg entailing the slope, inside which a series of successive walls delineate flat terraces, perhaps ancient irrigated fields.

\section{Buddhist carving and ruined Buddhist complex}

Opposite the ruined settlement, on the left side of the road, stands a passage chorten, and, about a hundred meters further down the road, to the south, a mani wall. Leaning against the latter, is a stela $(0.35 \times 1.63 \mathrm{~m})^{22}$ bearing a Bodhisattva in abhayamudra standing on a lotus base (Fig. 4). ${ }^{23}$ The deity wears a crown displaying four prongs and a central element, along with rounded earrings, a plain necklace and plain bangles at the arms, wrists and ankles. Although the piece might not be at its original location (it is broken in two halves), ruins of an ancient Buddhist compound are found in proximity. 
Figure 4. Sumur : stela with a Bodhisattva image (The slab is $0.35 \times 1.63 \mathrm{~m}$ )

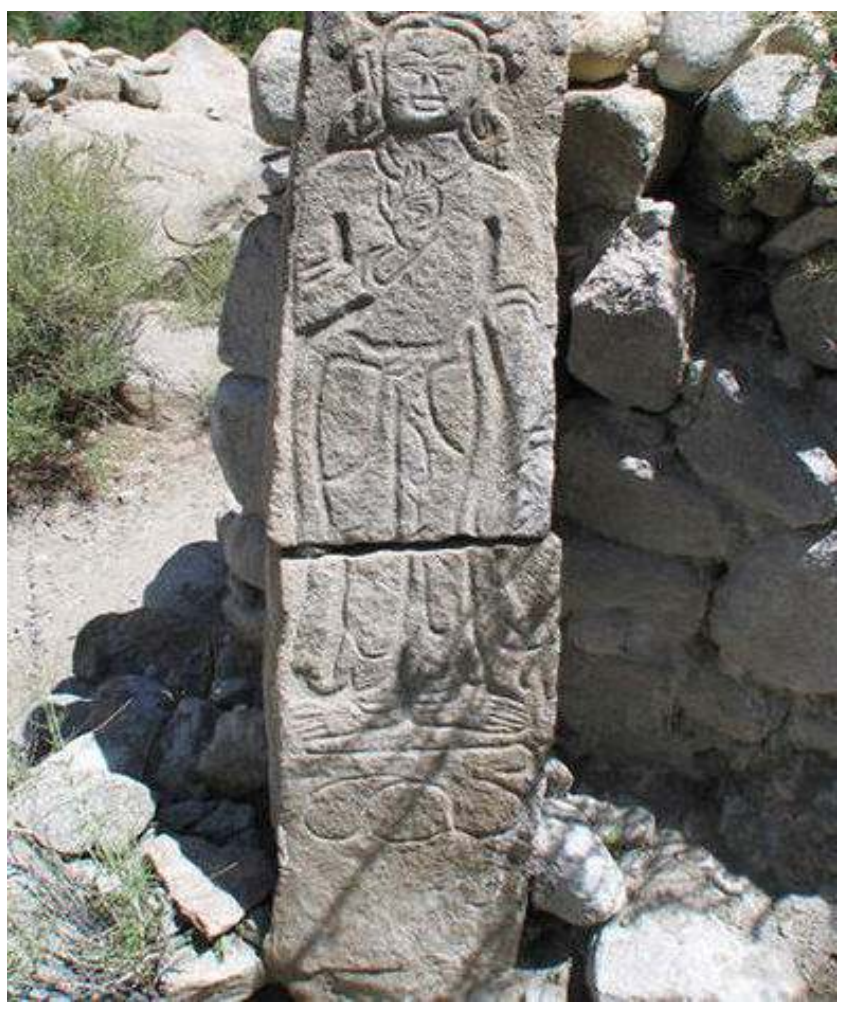

Bruneau 2006

15 The field next to the passage chorten is covered with rubble. Among those are the ruins of two large circular chortens, which are respectively $11 \mathrm{~m}$ and $6 \mathrm{~m}$ in diameter and about $5 \mathrm{~m}$ in height. Built on a large common terrace, the chortens seemed to have had respectively two and three platforms. Southeast are two other round structures of about the same size. The first one ( $7 \mathrm{~m}$ in diameter and $5 \mathrm{~m}$ in height) consists of a base made of one level topped by three small chortens. The second $(6 \mathrm{~m}$ in diameter and $5.5 \mathrm{~m}$ in height) consists of a base made of three levels topped by a pile of mani stones. On the south-western end of the compound is a long structure that appears to be a double mani wall. On its southern side is a fourth circular structure (about $5 \mathrm{~m}$ in diameter) with apparently one level only; while along the north-western edge is a small tsakhang (tsha khang). In front of the first two large chortens, the ground is covered with rubble and is marked with a series of hollows, likely former rooms. Part of the field is scattered with boulders that are now being turned into construction material. A former entrance alley can finally be discerned.

We have here undoubtedly a former Buddhist complex composed of a series of structures, among which two large central chortens and a series of rooms - perhaps buildings of religious use. The local oral tradition does not record the antiquity or function of the site.

17 Crossing the stream, a few hundred meters away, one reaches the monastery of Samstanling, behind which is a large Buddhist relief. 


\section{Khyagar}

\section{Buddhist carving ${ }^{24}$}

18 The relief (Fig. 5) is nowadays almost unreachable, as it stands within a jungle of thorny sea buckthorn bushes located on the northern side of the monastery. It represents two Bodhisattvas engraved on a boulder $(6.8 \times 4.2 \mathrm{~m})$. The Bodhisattva on the left $(1.70 \times 4 \mathrm{~m})$ holds a flower in his right hand, but this attribute is not specific enough to enable its identification. He has a nimbus and wears a five pointed crown along with rounded earrings, but no other jewellery. One can notice the highlighted cheeks and muscles of the torso. He wears a short dhotī (on his right leg the folds of drapery are visible at knee level), and a garland hangs from his waist. The Bodhisattva on the right, in abhayamudrā, does not display any attribute and therefore cannot be identified. His dhoți, held by a plain belt, is tight and forms a triangle between the legs. Over them, fourteen crude engravings of chortens were later added. A small platform is built in front of the rock. ${ }^{25}$

Figure 5. Khyagar : line drawing of the Buddhist carving behind the monastery of Samstanling (The carved area is $6.8 \times 4.2 \mathrm{~m}$ )

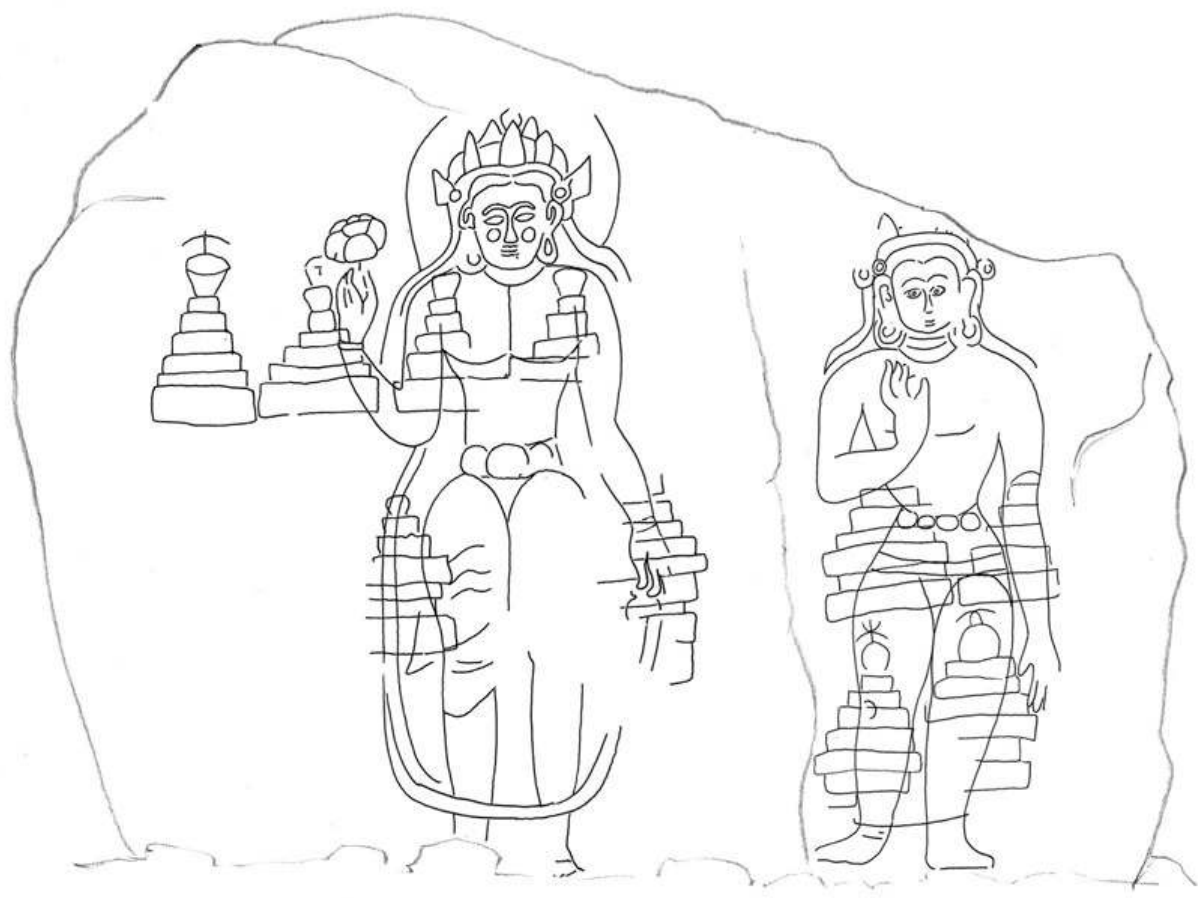

Vernier 2008

As the stela, ruined Buddhist compound and relief testify, the location where the monastery stands nowadays is historically linked to Buddhism well before the 19th century. ${ }^{26}$ We should mention here the small wooden head of a Buddha, obviously of a certain antiquity, displayed in the Central Asian Museum in Leh, and which was reportedly purchased in the village in the 1990 s. 


\section{Palace and old village} are the

Down from the monastery, on the right side of the link road reaching Khyagar village, are the ruins of an ancient settlement overlooked by a palace built along the mountain

f a respectable size, the palace has four floors and a line of four balconies on the second storey. Only the temple on the topmost floor is still in use. The best-preserved buildings of the former village are those in the immediate vicinity of the palace - some still have their roofs. Besides these is a small group of chortens, among which one has a painted passage. Just below is a terraced open square, with a long bench built against the retaining wall. The ruined habitations have rather neat and straight walls with perpendicular angles. The masonries use abundant mortar and do not integrate boulders. The walls are still well preserved in their elevation, usually above human size. The rooms are in average larger than $3 \mathrm{~m}$, some as long as 8 to $10 \mathrm{~m}$. The palace is locally said to have been built 6-7 generations ago (note that the duration of a generation is often locally understood as being that of a lifetime), and to belong to the Zimskhang family (gzims khang, literally 'sleeping place/house/room'). ${ }^{27}$

\section{Petroglyphs}

A series of lhathos and tsakhangs scatter the slope above the palace. Walking up and left from the latter, is the rubble of some construction built on top of an engraved boulder. Among the twenty or so carved motifs are ibexes, yaks, armed anthropomorphic figures with bow and spear, and a predation scene between a canine animal and a large bird. The latter has a set of stylised ears resembling horns, which could identify it as a khyung (mythical horned eagle).

\section{Sumur to Maral}

The side valley of Sumur and Khyagar, which leads to the pasture lands known under the name Maral, houses the remains of outstanding fortifications.

\section{Fort}

About an hour of walk from Khyagar, when the path leaves the torrent to go into the mountain, a small fort crowns a rocky promontory. Built mostly in stone, one low wall stands out for being in shuttered-mud (rammed earth). Ruins of habitations and enclosures are scattered in the slope near-by. In addition, a small structure can be seen perched higher up in the mountain, perhaps a former tower.

\section{Fortress}

The path continues with a steep ascent. After about another hour of walk, a large fortress appears in the mountain (Fig.6). Built in stones, with a double rampart, flanked by nice round towers and one quadrangular bastion, nearly $200 \mathrm{~m}$ in length, it is the largest fortress of Ladakh documented so far ${ }^{28}$ It is bordered on the south by cliffs descending into the torrent, on the west by steep slopes, on the north by short cliffs 
overlooking the trail coming from Khyagar, and on the east by a thin strip of flatland. This strip forming the weakest angle, a walled fosse entailing it through and through was dug in front of the rampart. In addition, a D-shaped outpost tower was built in front of this fosse, and a second tower, round, was erected a bit higher up in the mountain slope in order to defend this overall weak area.

Figure 6. Sumur Maral : fortress viewed from the north. The fosse can be seen on the left of the rampart, along with the second outpost tower straight below

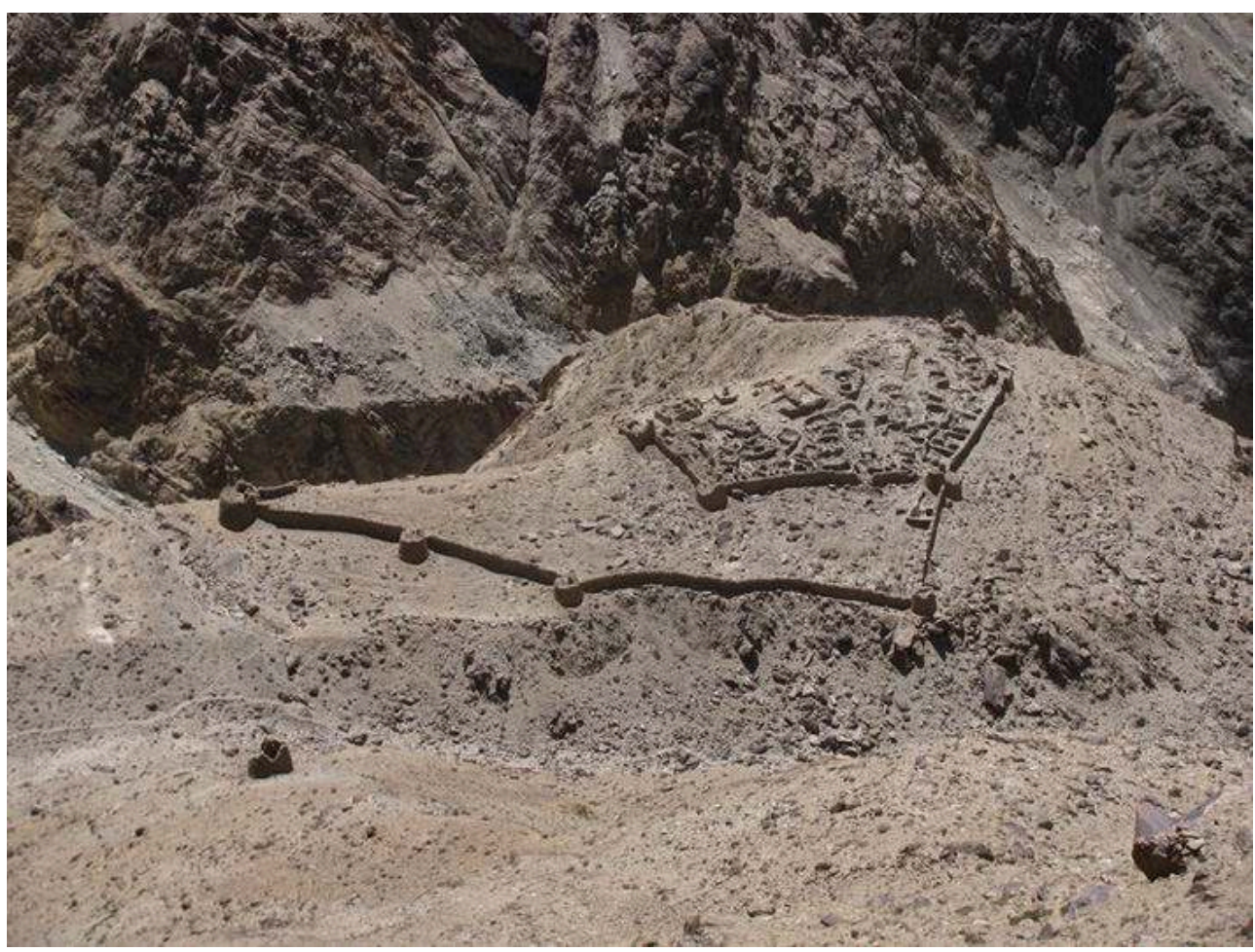

Devers 2011

The masonries of the rampart and of its flanking towers incorporate layers of bush branches. Some towers retain a few melted bricks $(40 \times 20 \times 12 \mathrm{~cm})$ in their upper elevation. Both outpost towers are built differently than those of the ramparts (their masonries, for instance, do not feature bush branches). They are most likely not contemporaneous with the other structures forming the fortress.

Altogether, there are about 80 rooms within the inner rampart and two more inside the outer one. Ceramic is very abundant and hearths were noticed. Almost all rooms are built in stone, except for two buildings using bricks as well, one possibly being a former silo (a construction subdivided into four small windowless compartments). Overall, two to three stages of construction can be identified. From the lowest tower, the remains of a built footpath can be seen descending the cliffs towards the torrent : the fortress had a protected access to water in case of a siege. Traces of metal work in the form of slags were found in the area delineated by the outer rampart.

This fortress is unique in the entire region. Such a double rampart flanked by round towers is nowhere to be found elsewhere in Ladakh, Tibet, Baltistan or in the Himalayas in general. This design reminds of some fortresses in the Pamirs, especially in the Wakhan Corridor. ${ }^{29}$ There, similar forts were used until the 6th-7th century ${ }^{30}$, but it is 
impossible, in the absence of hard chronological data, to determine whether the fortress of Sumur-Maral is contemporaneous or not. ${ }^{31}$

The fortress is situated about $500 \mathrm{~m}$ above the valley floor, an unusual high and remote location for such a large fortification. However, much higher up in the mountain, about $500 \mathrm{~m}$ higher up, i.e. about $1000 \mathrm{~m}$ above the valley floor, is yet another small fortified complex.

\section{Top tower}

This small complex consists in a watchtower surrounded by three defensive walls, and by several small terraces likely for setting tents. The tower (Fig. 7) underwent two stages of construction: a square tower was first built in dry masonry using bush branches, then, on one of its sides, a roundish extension was added in simple dry masonry without bush branches. The view from the tower is quite impressive. It opens downstream, towards the confluence of the Shyok and Siachen rivers, and upstream towards the mountain pass (name unknown) - unlike the fortress from which only the confluence is visible, a turn of the valley obstructing the view upstream..$^{32}$ This open view on the pass may well explain the function of the tower. Indeed, the valley on the other side of the pass joins the upper course of the Shyok river. At this junction are the ruins of an old fort, called Jurgolok ${ }^{33}$, Yarghuluk ${ }^{34}$ or Yurgolak ${ }^{35}$. According to a local tradition, this fort was built to protect a trail going to Sumur by way of the valley of Maral, supposedly used when the Saser pass was closed. ${ }^{36}$ As such, the tower above the fortress may well have had the function of watching the pass closing the valley, in order to warn the fortress in case of an attack coming from the Karakoram route. 
Figure 7. Sumur Maral : location of the top tower from the south, and close-up view from the northeast

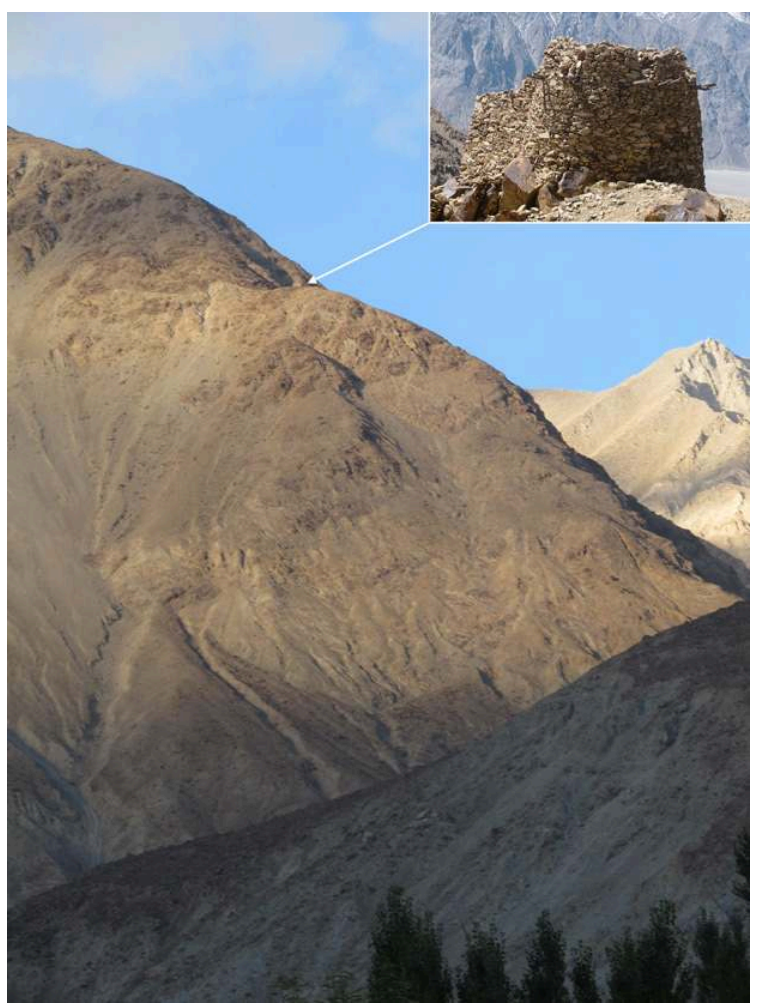

Devers 2011

\section{Chamchen}

Chamchen is a small village located half way between Khyagar and Tirisa.

\section{Tower and ruined enclosure}

Just after the village, at the mouth of a side valley, is a tower built in stones on the mountain slope on the left side of the stream. About $700 \mathrm{~m}$ after the bridge, the ruins of an old low rampart or enclosure can be noticed on the left side of the road.

\section{Chomolung}

Between the villages of Yulksam (the next village after Chamchen) and Tirisa, still on the left bank of the Siachen, one comes across a barren track of land known as Chomolung.

\section{Petroglyphs and inscriptions}

After Yulksam one can take the ancient track climbing above the rocky ridge through which the modern road was cut. This ancient track is said by some local informants to be the first attempt of a motorable track made in the late 1960s to reach Panamik. Along the latter, still well paved, in two places are found four large engravings of 
chortens, of which three are accompanied by Tibetan inscriptions. ${ }^{37}$ Two of the inscriptions, in umet ( $d b u$ med) script, display archaic features such as the reversed $i$. One of them mentions a date, expressed as yos bu'i lo or "year of the hare", showing that the sexagenarian circle of years was obviously not in use.

Along the modern road, on the cut surfaces of the rocky ridge we noticed a panel of about 50 engravings, most of them heavily patinated. There are interesting petroglyphs of ibexes, stag and yaks in a style that could be attributed to the Bronze Age. Among those animals is a large human figure, with mace and quiver at the waist. Some motifs are later additions, such as camels, riders and anthropomorphic figures represented as if standing on the back of the former ibexes and yaks.

\section{Tirisa village}

In the middle of the village, few meters down the road, is a holy footprint sheltered by a small mud-brick structure. The foot imprint is said to belong to Dachompa Nyima Gungpa (dgra bcom pa nyi ma dgung pa) ${ }^{38}$ and is part of a set of four such prints left in Nubra by this great tantric master on his way to Tibet. ${ }^{39}$

After the village of Tirisa one reaches a rather large alluvial fan, locally known as Kushuwar Thang.

\section{Kushuwar Thang}

\section{Petroglyphs and inscriptions}

Although many boulders of the alluvial fan had already been broken into building blocks, we were able to document 102 petroglyphs. The rock art site stretches over a barren area from the road up to the mouth of the narrow valley at the top of the fan (about $350 \mathrm{~m}$ ). There stands a large lhatho painted in ochre with white stripes. The engravings are found at two locations : on scattered boulders in the lower part of the fan, and on rock faces in vicinity of the lhatho.

The boulders bear fourteen inscriptions in Tibetan, both in capital and cursive letters, associated with chortens of various types. The inscriptions are obviously of various impulses. They are mostly dedicatory and include names and titles. One of the inscriptions in $d b u$ can script displays archaic features such as the reversed $i$ and mentions the "year of the tiger" or "stag gI lo", showing that the sexagenarian circle of years was obviously not yet in use.

Apart from inscriptions and chortens, the rock faces in vicinity of the lhatho bear deer and ibexes in a local adaptation of the Iron Age "animal style". The animals are depicted as if standing on the tip of their hooves. Their body shape, with the hindquarters higher than the forepart and the arching of the back, is also characteristic of the style. Another deer has its head turned backwards on its back with antlers depicted as if viewed from the front. On the same surface one finds a birthing scene which is unique in Ladakh (Fig. 8). The engraving is, even if rather coarse and irregular, quite realistic. It shows a woman (the breasts are represented as two triangles) in a squatting position. Her right arm is raised while her left hand seems to grab her newborn baby depicted on her side. The umbilical cord is clearly drawn. On a large 
block, next to this very unique delivery representation, are two standing characters engaged in what might be a sexual fondling, unless it depicts the preceding step of the delivery scene and represents a woman assisted by the other character. The scene is unfortunately not clear enough to decide, but such narrative representations involving humans are so far unique for the Ladakhi rock art corpus.

Figure 8. Kushuwar Thang : rock art site. Birth giving scene

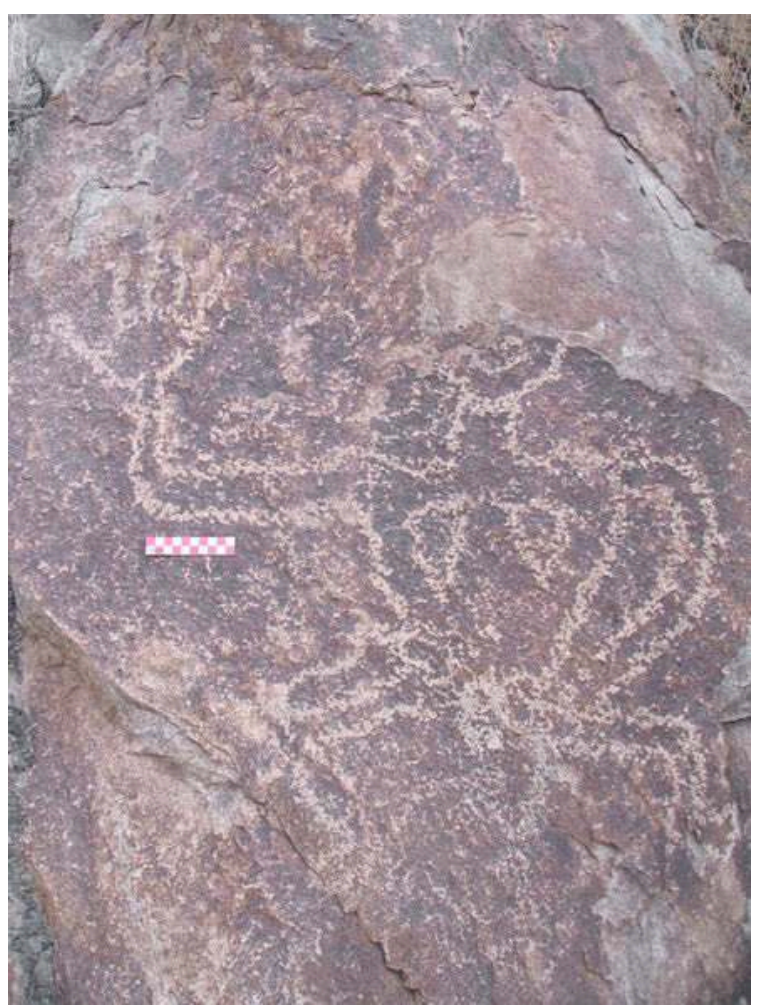

Bruneau 2011

\section{Other remains}

The ground in front of the engraved boulders is levelled and flattened, and there are remains of dry masonry platforms. In the vicinity, at the bottom of huge boulders, are ruined low walls in dry masonry delimiting rock shelters. One of them is large enough to accommodate several dozens of persons, standing, and its whole inner ground is laid out. No lithic tools or pottery were found and the shelter was and still is used by shepherds.

Nearby, on a small promontory, are remains of a rectangular building with two rooms in dry stone. This structure was built on a more ancient one, with an obvious reuse of some of its building material. Its location at the breach of a slope provides a very good view of the valley, and it might have previously been a defensive construction. Some metal slags have been collected around the building.

Other defensive buildings are found a few hundred meters further north. They consist in half a dozen of rooms that are organic in shape, divided in two groups. A first one is at the very end of the fan on an almost flat ground. A second group of rooms is found about a hundred meters above, built in the slope more or less in a row. 
the other side of the same alluvial fan, slightly down the slope and between several runoff ravines, are several structures of low piled-up stones. These structures present various degrees of construction, but they are all built on a rather square base. They are possibly ancient graves. Many fragments of wide terracotta containers were collected in their immediate vicinity.

\section{Tirisa lake}

Tirisa is well known for its small lake, locally known as Lophan Tso, enclosed in a geological formation that stands out in the landscape. Indeed, it protrudes in the middle of a flat sandy desert on one side, and the flat riverbed on the other side. The lake is one of the major pilgrimage places of the Nubra and one of the legends associated to it, linking it to Ensa, is discussed further below. ${ }^{40}$ Lithic artefacts were reported in the surroundings of the lake by the ASI. ${ }^{41}$

\section{Large ruined building}

The northern tip of the geological formation ends with a small promontory that is detached from the main rock. It is crowned by a large building, roughly $40 \times 20 \mathrm{~m}$ in size. Its walls are well preserved, up to a height of $1.5-2 \mathrm{~m}$, and are $50 \mathrm{~cm}$ thick in average. One wall bears the imprint of a former timber lacing. According to the locals, until the construction of the modern road it was used to store soda. It is still known under the name of Phul Porsa (phul por sa, "the place where salt/soda is stored"). Indeed, the plain around Tirisa is known for the quality of its salt, which was used throughout Nubra and even Ladakh until recently.

\section{Fortified settlement}

The remains of a fortified settlement can be seen on the hilltop that dominates the northern side of the lake. It is defended by a rampart that follows the edge of the cliff. The area thus delineated is roughly $5 \mathrm{~m}$ wide. The entrance, in the form of a few steps going through the rampart, is found on the western edge, which is the least accessible side. Buildings cover only part of that space, counting about twenty rooms. A few more are probably to be added as the site is, overall, in a very ruinous condition. This state of conservation seems to be the result of a deliberate destruction and not of natural decay. The habitations with the best-preserved walls are located on the northern part of the site, where the topography is flatter. They are mostly quadrangular in shape and retain an elevation of about $50 \mathrm{~cm}$. The walls, made of stones, are $40 \mathrm{~cm}$ thick in average and do not integrate boulders at their base. The eastern edge of the settlement is the culminating point, with structures that are more strongly built and that are probably related to defence. A chorten is carved on the rock face between this culminating point and the habitations. Ceramic is found in good quantity, among which we noticed one shard with incised motifs. Overall, the different parts of the site seem to be of one main single stage of construction.

Études mongoles et sibériennes, centrasiatiques et tibétaines, 46 | 2015 


\section{Fort}

48 $50 \times 20 \mathrm{~m}$. Its walls were mostly built in bricks (size of the bricks : $41 \times 22 \times 10 \mathrm{~cm}$ ) with an average thickness of about $50 \mathrm{~cm}$. It is one of the few forts built with bricks in the Nubra region and more generally in Ladakh. ${ }^{42}$

\section{Petrogyphs and inscriptions ${ }^{43}$}

On the northern and southern shores of the lake, are ten or so engraved rock faces and boulders. Except for a few recent and fair images, the petroglyphs are heavily patinated with coarse and wedge-shaped impacts typical of stone tools. There are only scenes with wild animals (yaks and ibexes), no human figure was documented.

Historical engravings are found on the outer rock faces of the geological formation: about thirty surfaces bear depictions of ibexes along with horsemen, chortens and three Tibetan inscriptions. These are all engraved on a single surface along with ten images of chortens. (Fig. 9). The three inscriptions in dbu med script are engraved on the side and below a five-tiered chorten. Two of the inscriptions are obviously contemporary to the image and are dedicatory. ${ }^{44}$ The longest one is most probably expressing a date using the rab-'byung sixty-year cycle.

Figure 9. Tirisa lake : Tibetan rock inscription and chortens

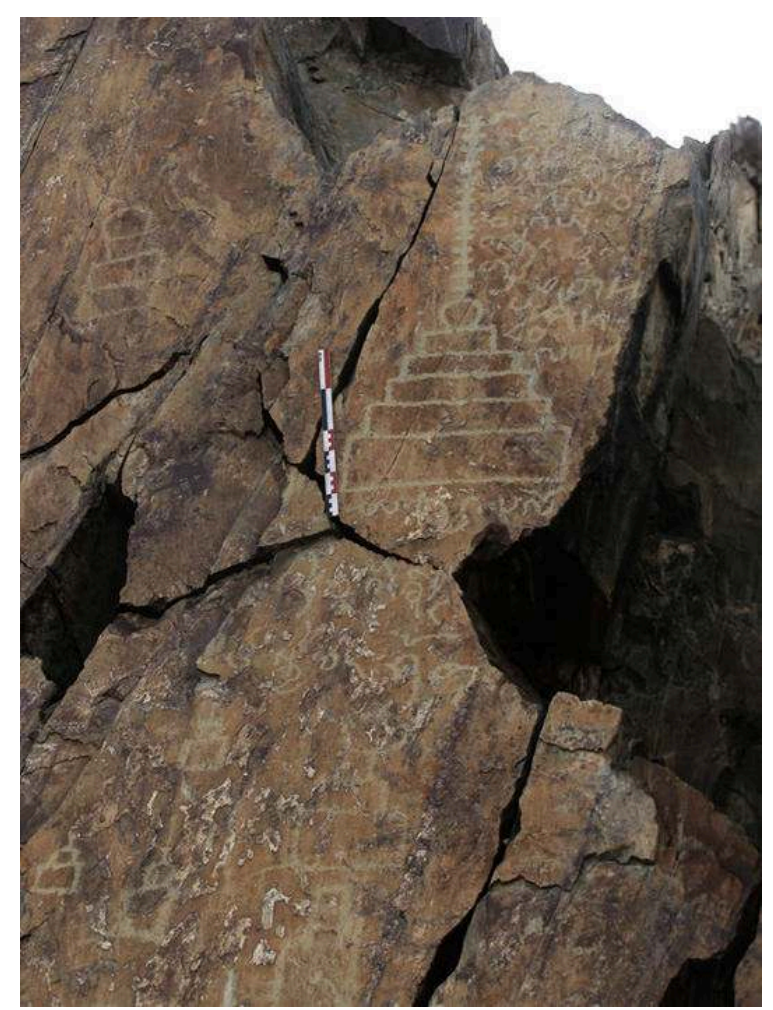

Devers 2011 


\section{Ruined chorten and related remains}

51 About $600 \mathrm{~m}$ east of the inscription is a large ruined chorten ${ }^{45}$ (Fig. 10). Made of stone, with a height of about $10 \mathrm{~m}$, it is erected on an artificial rectangular terrace $(20 \times 25 \mathrm{~m})$ delineated by an enclosure. It presented a ladder on each side, the one on the western being the best preserved. The base and platforms are heavily damaged and their number as well as their shape (either circular, rectangular or cruciform) is difficult to ascertain. The dome and superstructure have vanished completely and the wooden central pole, well preserved, sticks out at the top of the ruined monument.

Figure 10. Tirisa lake : main ruined chorten of the ancient Buddhist complex from the east (about $10 \mathrm{~m}$ in height)

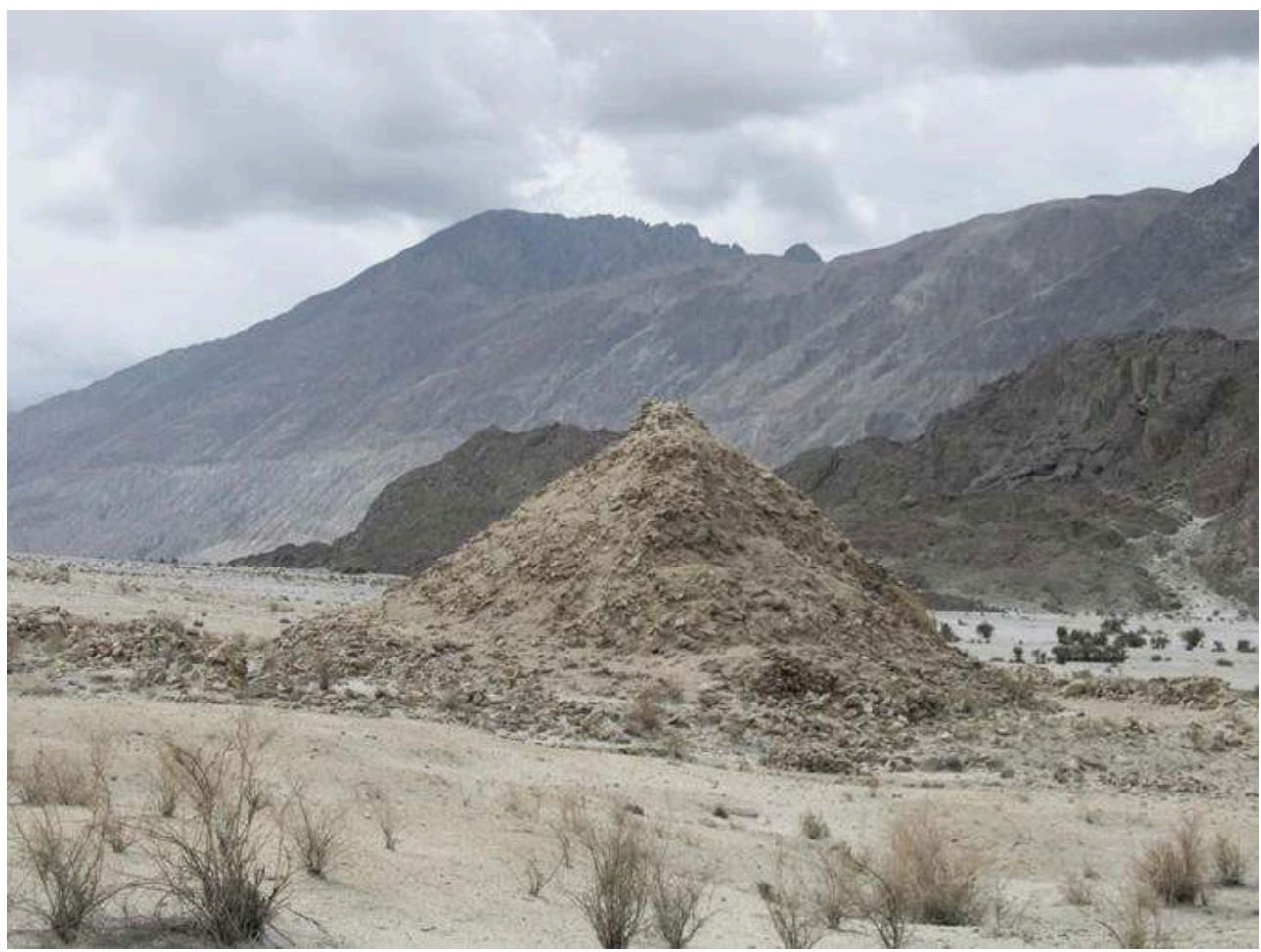

Devers 2011

In the area around the chorten, several rows of small mounds of rubble and melted mud can be seen - probably decayed small chortens. Due south to the main chorten is a small platform built with large bricks. Along the road, the ruins of two rooms built in brick are also found.

53 No doubt that these various remains were part of an ancient Buddhist complex. It should be noted that in 2013 contractors started to dismantle the enclosure of the chorten and digging the surrounding ground in search for construction material. 


\section{Panamik}

\section{Ruined settlement}

Ruins of an ancient settlement are found on the alluvial fan above the cultivated fields, on the right side of the stream. It is divided in two distinct groups of habitations. In the first one the constructions are mostly rectangular, built on flat neatly levelled terraces that are $3-4 \mathrm{~m}$ in size in average. Walls do not integrate boulders and are rather neatly built using mixed-cobble masonry. Most of them are preserved at an elevation of roughly $1.5 \mathrm{~m}$, several being totally flat on their top without any rubble around: it tends to indicate that it was their original height.

In the second, smaller, group of habitations constructions are in a general way larger and more oblong, several are $6 \times 3 \mathrm{~m}$ and one measures even nearly $10 \mathrm{~m}$. It would prove interesting to proceed to excavations in both clusters as the ground of the terraces has a somewhat important natural sedimentation, which is not all that common in Ladakh. Above the ruined settlement, along the edge of the cliff, is a boulder engraved with three riders.

\section{Petroglyphs}

More petroglyphs are found on rock faces further north, where the road comes along the mountain side. They consist in five depictions of chortens and two Tibetan inscriptions in Tibetan $u$-chen (dbu can) script. Above these carvings, on top of the cliff, are the remains of an ancient funerary site.

\section{Funerary site}

The graves have all been looted in olden times, as the advanced weathering of the opened ground indicates. The tombs consist in arrays of stones set into the ground, with hollow pits in the middle resulting from the looting. They are either circular or rectangular in shape. Circular tombs are more numerous, and range from two to five meters in diameter. In some pits, a stone wall starting right from the surface downwards and corresponding to the funerary chamber is visible. In the case of rectangular graves - some are $10 \mathrm{~m}$ in length - the underground wall starts one to two meters below the surface. There are also small rectangular graves that are placed against boulders. These various types of tombs are found mixed together, in different clusters scattered over the slope. Altogether we counted about fifty graves.

The rubble of an ancient construction stands on a rocky promontory on the lower part of the site, but, given its dilapidated state, its function is difficult to establish. Further north, a few other looted tombs and two other ruined constructions, standing on rocky promontories, are to be observed. ${ }^{46}$

The characteristics of these graves (quadrangular and circular arrays of stones set into the ground) remind of those found in Western Tibet ${ }^{47}$ and across Central Asia ${ }^{48}$, which have been dated from the Bronze and Iron Ages. 
60 Adjoining Panamik is the village of Hargam, which is the limit set for foreigners. There, a bridge enables to reach the right bank of the Siachen river. The first locality downstream is Ensa, famous for its highly situated monastery.

\section{Ensa}

\section{Petroglyphs ${ }^{49}$}

61 Ensa monastery could, until very recently (2011), be reached only by a steep footpath along which are two engraved boulders. The first one, on the way up, bears an interesting scene composed of ibexes, horses, horsemen and a 'mascoid'. Noticeably, a horse is held on a lead by an anthropomorphic figure standing in front of it. Such a scene of domestication is rare in the rock art of Ladakh, as is the depiction of a 'mascoid', which we will discuss further down. The other boulder is found along the flat part of the trail just before reaching the monastery, and bears the carving of a chorten.

\section{Ancient chortens}

Reaching the plateau where the monastery is set, are about fifty chortens. ${ }^{50}$ Among them several are of interest to us because they exhibit lotus-moulded petals on their plinth, a motif rarely preserved in Ladakh. ${ }^{51}$ One also has traces of red paint and miniature clay chortens on the upper part of its plinth (Fig. 11). Except for Malakartse Khar chorten in Zanskar, it is the only other known example in Ladakh. ${ }^{52}$

Figure 11. Ensa : chorten with miniature clay chortens on its plinth from the west (The scale on the green folder is $40 \mathrm{~cm}$ long)

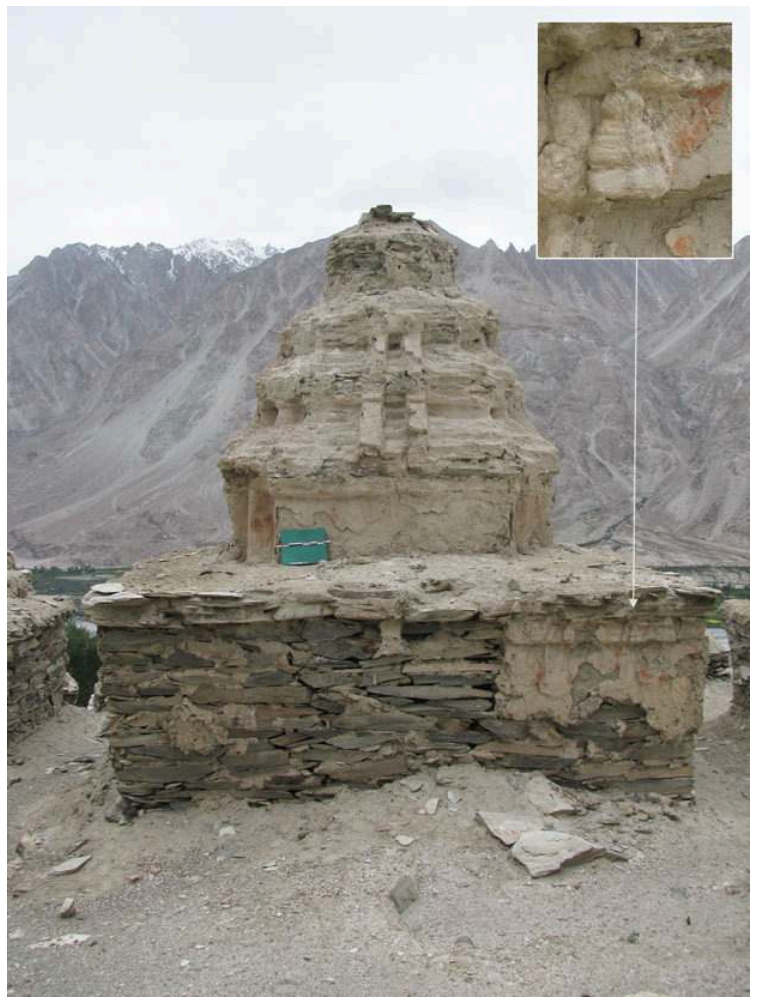

Devers 2010

Études mongoles et sibériennes, centrasiatiques et tibétaines, 46 | 2015 


\section{Buddhist carving}

Among the chortens is a little shrine sheltering a stela (about $0.85 \times 1.25 \mathrm{~m}$ ) of Avalokiteśvara in rājalilāsana, identifiable by the Buddha in his crown and the lotus hold in his left hand (Fig. 12). Avalokiteśvara has a nimb and halo, and wears heavy round earrings as well as a necklace and pointed armbands. In 2010, the shrine was included in the wall of a small temple room, facing the door..$^{53}$

Figure 12. Ensa : line drawing of the stela with the figure of Avalokiteśvara (The carved area is $0.85 \times 1.25 \mathrm{~m})$

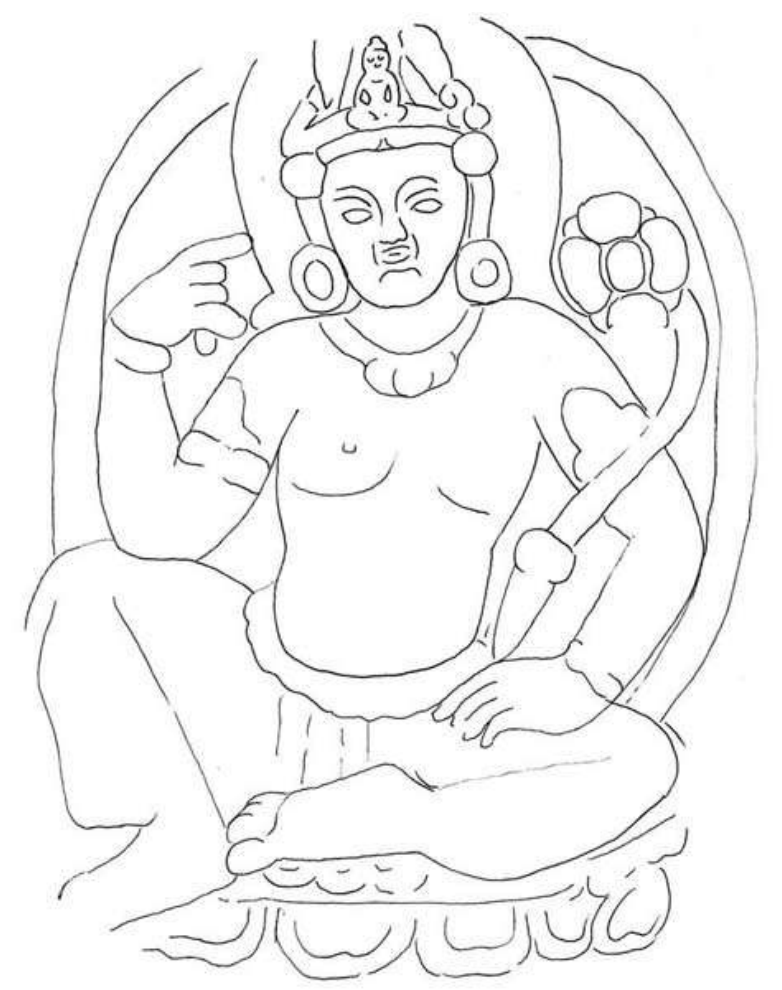

Vernier 2008

According to the local tradition, the location where the monastery now stands was first a meditation retreat used by Sherab Zangpo (shes rab bzang po) around 1430, only later it was turned into a monastery. ${ }^{54}$ Among the antiquities are three wooden pieces, formerly painted, carved in shape of lions (Fig. 13). The lions display protruding eyes, open jaws, hanging out tongues, a pearl necklace and a flower motif between the back legs. Similar wooden lions are used in Ladakhi temples of the 12th-15th centuries either as consoles, beams' ends or portico elements, the most famous examples being those of the Alchi Sumtsek. ${ }^{55}$ 
Figure 13. Ensa : one of the wooden sculpted lions

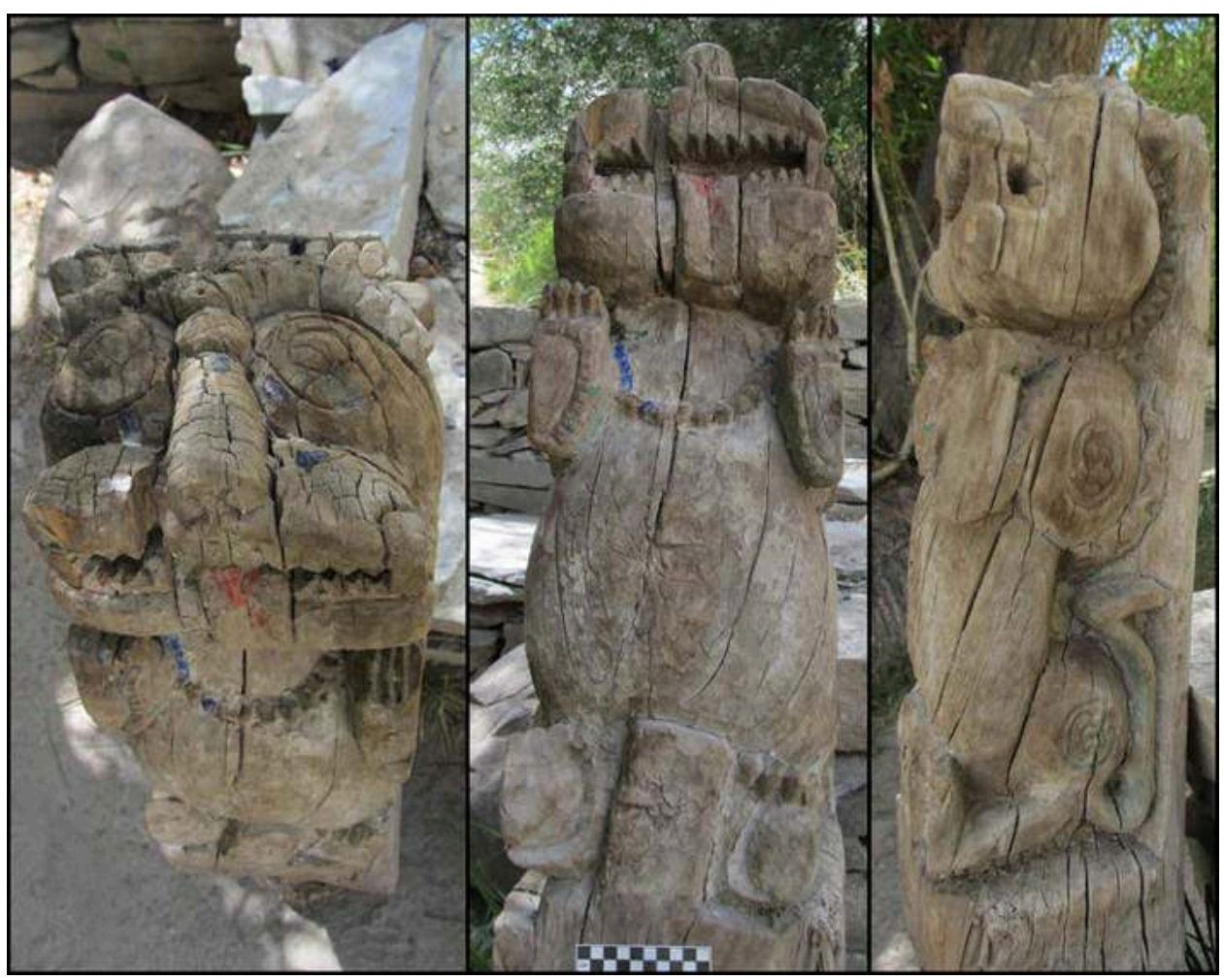

Devers 2013

A last noticeable curiosity at Ensa monastery is a footprint attributed to Dachompa Nyima Gungpa. ${ }^{56}$ According to the local tradition, this monk was able to fly by using his garments. It is said that he refused to build the "Lhasa Gonpa" at Ensa. Thus he left the print of his right foot on a rock at that location and flew away to Tibet to build it. No "Lhasa Gonpa" is known neither in Tibet nor in Ladakh, but the local tradition asserts that it is this very same gonpa that one can see in the reflection of the waters of Tirisa's lake. The footprint is strangely realistic and shows no signs of use of tool. Another footprint of this type can be seen at Murgi, the closest village to Ensa monastery.

Between Ensa monastery and the modern village of Murgi, one finds one of the largest archaeological site of the Nubra region, that of Murgi Tokpo.

\section{Murgi Tokpo}

The site is composed of various types of remains (petroglyphs, ruins of habitations) all located in the alluvial fan of the torrent (tokpo) of Murgi. ${ }^{57}$

\section{Petroglyphs}

The inhabitants of Murgi appropriately know the rock art site under the name ' $r$ do nag', literally meaning 'black rocks', as it is formed of boulders covered with a red-brown crust. Due to the peculiar color of the rocks, the site clearly stands out in the surrounding landscape (Fig. 14). Also, from the top of the site, one has a panoramic view of the valley (Fig. 15). 
Figure 14. Murgi Tokpo : general view from Panamik in the east. The various zones of the rock art site are indicated with Roman numerals (I to VI)

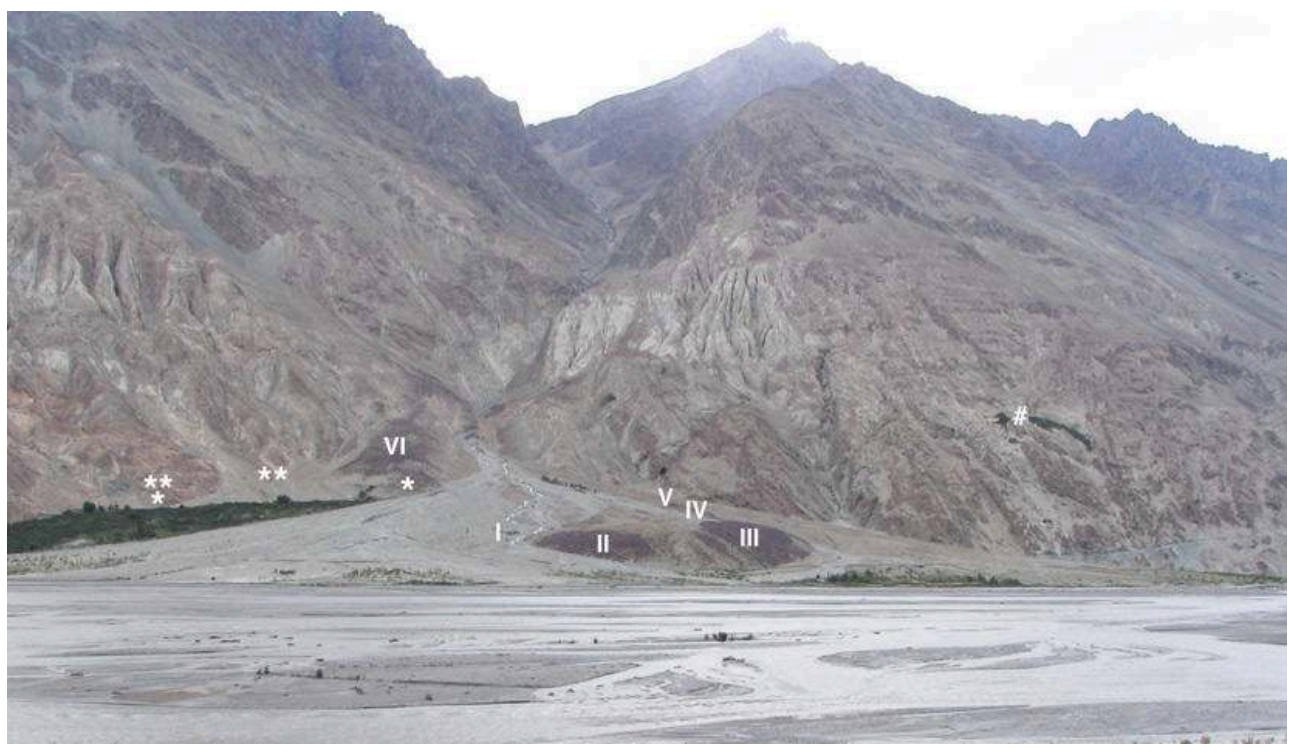

Other remains are visible : the ruined settlement is designated by the single star ; fort A and B are respectively pointed to by the two and three stars ; and the location of Ensa is indicated by the hash tag.

Devers 2010

Figure 15. Murgi Togpo : view from the top of the rock art site, looking northeast towards Panamik

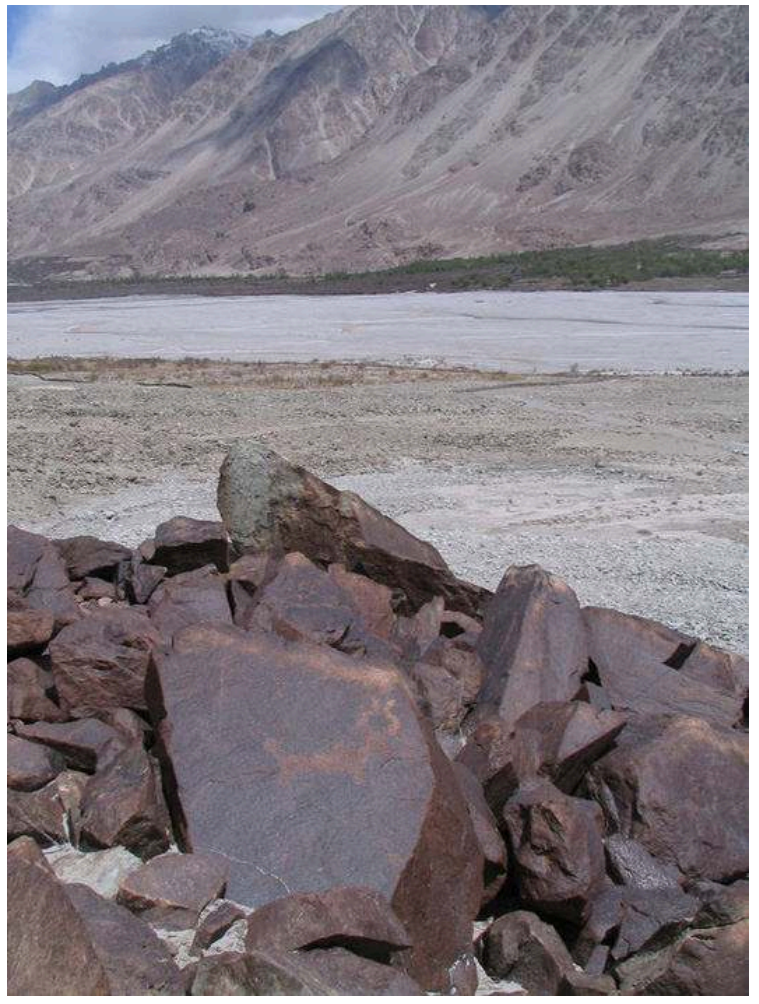

Bruneau 2011 

typical of the site. They most frequently show one or two hunters on foot, helped by dogs. Duel or battle scenes of archers are also common. There are rare images of hand and foot prints as well as camels and riders (Fig. 16).

Figure 16. Murgi Tokpo : rock art site : recording on transparent sheets of various figures and scenes

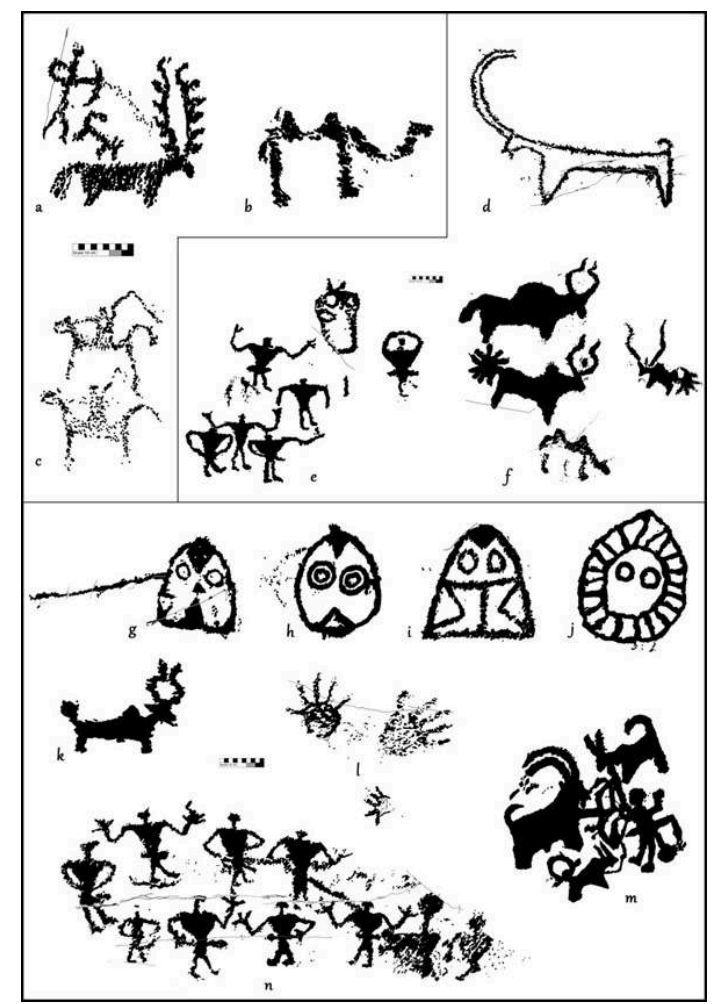

$a$ : deer hunting scene ; $b$ : camel ; $c$ : two horsemen ; $d$ ibex ; e : group of anthropomorphic figures ; $\mathrm{f}$ : three yaks and a camel ; $\mathrm{g}$ to $\mathrm{j}$ : 'mascoids'; $\mathrm{k}$ : yak; $\mathrm{l}$ : hand prints; $\mathrm{m}$ : hunting scene; $\mathrm{n}$ : group of anthropomorphic figures

Bruneau, Vernier \& Devers (2007 \& 2011)

Emblematic of Murgi Tokpo are 'mascoids' (Fig. 16). A hundred or so were recorded at the site whereas only a dozen is known for the rest of Ladakh. As demonstrated in previous works, mascoids are typical of the rock art of Inner Asia, especially South Siberia and the Altaii, for the Bronze Age. ${ }^{58}$ Other stylistic features such as the path of 
arrows engraved in fighting or hunting scenes, hunters with maces or quivers at their waist, anthropomorphic figures with mushroom-like headdresses or else animals with a ball-tail are also characteristic of Central Asian rock art attributed to the Bronze Age. ${ }^{59}$ On a comparative basis we propose a similar timeframe for the petroglyphs of Murgi Tokpo.

Being the largest rock art site of Ladakh (3301 petroglyphs carved on 877 boulders), Murgi Tokpo deserves an in-depth thematic and stylistic analysis to better apprehend its artistic and cultural links with Central Asia but also its relationship with surrounding remains. Indeed, some engraved boulders from zone VI are incorporated into the walls of ruined habitations.

\section{Ruined village}

According to local beliefs, the ruined village is said to be part of a bayul (sbas yul), literally 'a hidden land' (ba ces / sbas byes : to hide to conceal, and yul : village, country). This is a recurrent association in Ladakh and there might be a local belief through history of an existing link between rock art sites, very ancient settlements and bayuls. ${ }^{60}$

The village is composed of over 50 rooms ( $2 \mathrm{~m}$ to $5 \mathrm{~m}$ size in average), which are rather organic in shape. The walls are still standing up to $1.8-2 \mathrm{~m}$ tall and integrate boulders. Surface pottery is abundant in the rooms and few metal slags were also noticed. On the southern edge of the village, in the slope, there is a long rectangular building. Its design, size and preservation are very different from the other constructions : it does not integrate boulders, walls are neat and straight, the terracing of the ground makes use of timbers. One of the rooms has mud-coat on the walls with traces of red pigments. Small chortens and tsakhangs are found in vicinity. According to villagers it was a retreat place (mtshams khang), where a single monk used to live to practice meditation.

\section{Murgi village}

\section{Fort A}

The ruins of a first fort (A) stand on a rocky outcrop about 200m southwards. At the foot of the outcrop is a row of six contiguous rooms ( $4 \times 5 \mathrm{~m}$ in average). They are built on the edge of a dry trench formerly dug by a torrent, using the trench as a defence feature. From these rooms, the lower courses of a rampart $70 \mathrm{~cm}$ thick run towards the top of the outcrop. There, it keeps a distance of $2.5 \mathrm{~m}$ from the outer buildings of the fort. There are in total about a dozen rooms across the fort. These are organic in shape, with rather curvy walls. Their size ranges between $3 \mathrm{~m}$ and $6 \mathrm{~m}$. The walls are $30-40 \mathrm{~cm}$ thick in average. The cliffs are used as natural ramparts on the eastern edge. The state of conservation of the site is similar to the ruined village of Murgi Tokpo described previously, as is the general organic shape of the rooms.

\section{Fort B}

The second fort (B) is built on a similar layout, but the topography is somehow different, resembling more a ridge than an outcrop. Like for Fort $\mathrm{A}$, at the foot of the slope are a few rooms lined along a rampart that goes towards the top of the fort. It is 
also set at a distance from the outer buildings (about $2 \mathrm{~m}$ ). A space was dug to create some sort of small fosse between these outer buildings and the rempart. ${ }^{61}$ Facing the rampart is a square building, $3 \times 3 \mathrm{~m}$ in size. Its masonry is reinforced by bush branches as for the towers of the fortress above Sumur. The rest of the fort is very ruinous and it is hard to identify a precise plan. On the southern and eastern edges, cliffs are used as natural defences.

\section{Fort C}

Far above the village, dominating a waterfall, a rocky promontory is crowned by a low rampart. It is roughly $65 \mathrm{~cm}$ thick and preserved on a height of $40 \mathrm{~cm}$ to $80 \mathrm{~cm}$. Its course stops when it reaches the cliff. Not so many stones can be seen on the ground, indicating that the rampart was not much higher in its original state. Two inner circular rooms are on two curves of the rampart. The bases of a few other walls are visible inside the thus delineated area, but their traces are too faint to draw a coherent plan. On the western edge of this rampart, few petroglyphs are carved on the surface of the rock.

\section{Foot print}

As previously mentioned, Murgi village houses another footprint left by the tantric master Dachompa Nyima Gungpa whilst departing from Ensa to go to Tibet. ${ }^{62}$ Not far from the enclosed footprint, on the right side of the road is an ancient chorten partly buried.

\section{Ancient chortens}

This chorten is of the ladder (lha bab, 'descent from heaven') type, rarely found in Nubra region. It is partly buried due to a large quantity of sediments that were brought by past floods. ${ }^{63}$ (Fig. 17, a) As such, its plinth is not visible and its ladders descending from the top of the upper platform go directly into the ground.

Down a footpath on the other side of the road is a passage chorten, also partly buried (Fig. 17, b). Datable from the first half of the 14th century through its murals ${ }^{64}$, it is nowadays difficult to enter the monument as the passage has been almost entirely closed off by the accumulation of sediment brought by floods. Near the waterfall that marks the southern edge of the village is another group of chortens, some erected on plinths decorated by lotus petals (Fig. 17, c).

Two more ruined chortens are found in the barren area south of the waterfall. One is composed of five platforms of diminishing size built of mud bricks $(40 \times 22 \times 11 \mathrm{~cm})$ on a square base of mud stone masonry ${ }^{65}$ (Fig. 17, d). The dome that might have topped the whole almost totally collapsed. The structure has a closed inner chamber located under a wooden frame that is nowadays partly visible due to the advanced decayed state of the chorten. The second one, of the ladder type, is located a little further up. Only the eastern side still shows the initial shape of the structure as the others collapsed. It is built in a stone mud-mortared masonry with bricks on the upper parts $(36 \times 26 \times 1 \mathrm{~cm})$, largely plastered with mud. 
Figure 17. Murgi village : ancient chortens

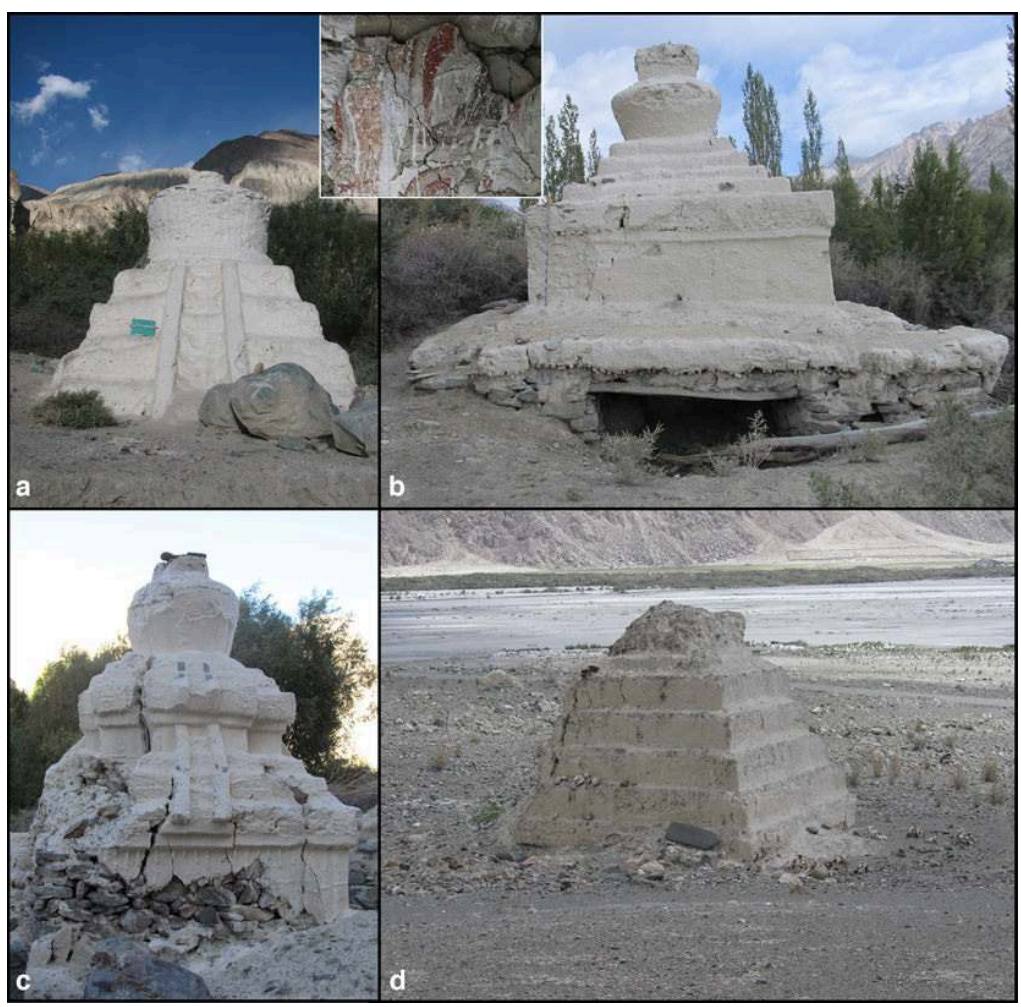

a : partly buried ladder chorten (The scale on the green folder is $40 \mathrm{~cm}$ long) ; $\mathrm{b}$ : partly buried passage chorten with detail of its murals (the scale-tape is $1 \mathrm{~m}$ long) ; $\mathrm{c}$ : chorten with decoration of lotus petals (size not known); $d$ : chorten with five diminishing platforms (r. 3.5m high)

a, b, c \& d : Devers 2010 ; detail of the murals : Vernier 2013

\section{Petroglyphs}

83 Leaving Murgi village to go to Guri, at the south of the barren area, where the road meets a modern canal, one encounters large brownish boulders. There, we documented 463 petroglyphs scattered on 49 boulders. There were certainly more since the lower part of the rock art site has been altered and partly destroyed by the construction of the canal.

Except for a few heavily patinated animals, the petroglyphs have a medium patina. The main topics are : chortens, ibexes (isolated or in groups), horses and groups of riders. There are two rare depictions of anthropomorphic figures armed with a pickaxe. One is very large $(110 \times 125 \mathrm{~cm})$ and shows the figure brandishing the weapon : it is unique in Ladakh. Large images are typical of the site : there are horses with an indented mane over a meter wide. (Fig. 18). All are represented with four bended legs, two pointed ears and an arched tail. Three such horses are mounted: the bridle is clearly carved and in one instance the saddle is visible. One of the riders seems to wear a Phrygian headdress. These images, combined to the various group of riders represented at the site, may indicate an Iron Age date. Interestingly, a large vertical rock at the bottom of the site provides space for shelter and the ground was undoubtedly cleared, but we did not find any occupational remains. 

river.

Figure 18. Murgi village : rock art site : equid figure

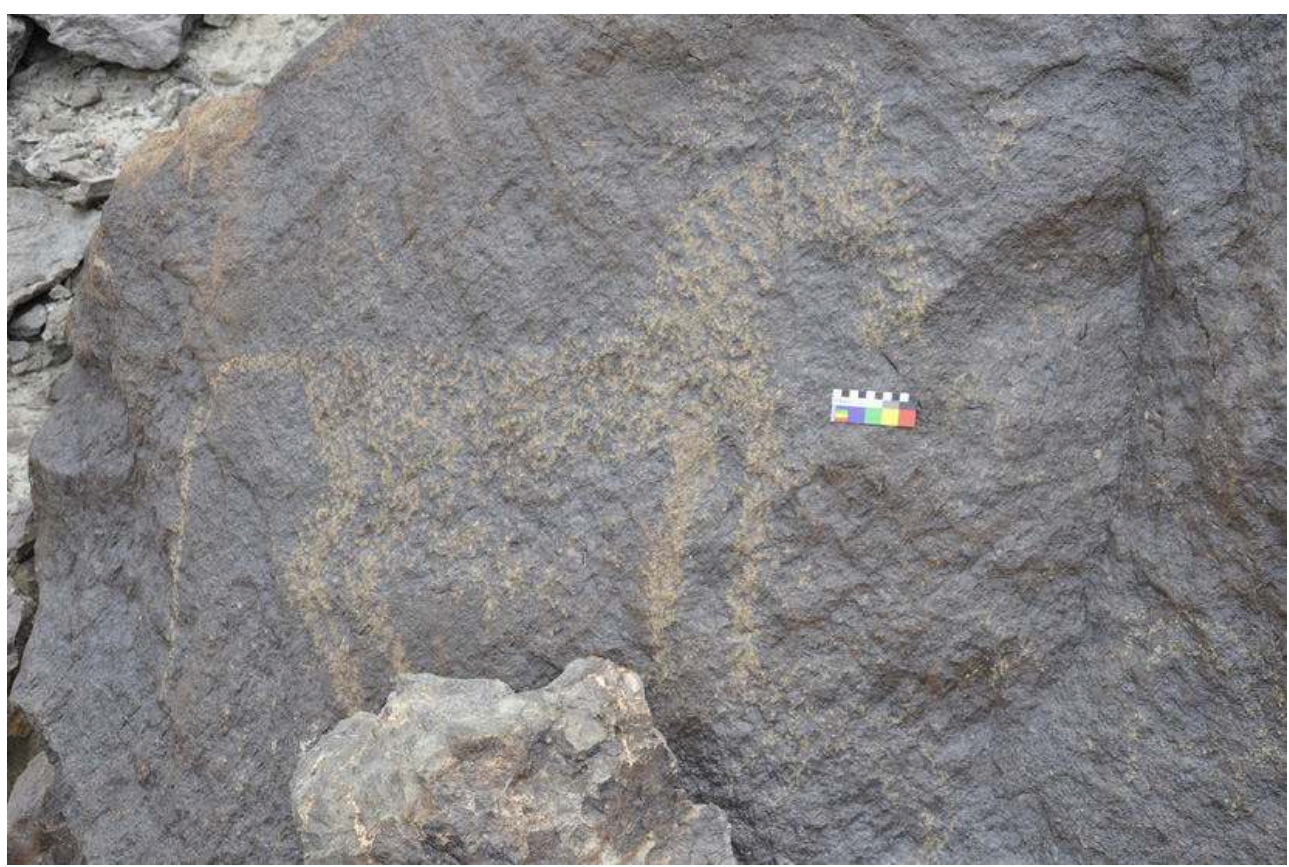

Bruneau 2013

\section{Guri}

\section{Petroglyphs}

There are twenty or so engravings on rock faces near the monastery. The patina is fair in most cases and the images consist mainly in ibexes and chortens.

\section{Ruined temples ?}

87 At the entrance of the village when coming from Murgi, on the left side of the road, is a small open square with chortens and the ruins of two adjacent constructions in bricks (A and $\mathrm{B})$. Their elevation is completely gone : only a raised platform and the base of the walls are left. Though very weathered, partly melted and difficult to accurately measure, the size of the bricks seem to be $45 \times 28 \times 11 \mathrm{~cm}$. The characteristics of these two constructions - elaborate design on a raised platform, use of bricks, built environment composed of chortens - remind us of temples. ${ }^{66}$

\section{Ruined habitations}

The area on the mountainside facing the monastery, on the other side of the fields, is scattered with rubble and ruins of curvy walls. It is overall too ruinous to be further described. These are probably the ruins of an ancient village. 


\section{Charasa}

At the southern end of the village of Charasa, a rocky formation entering into the riverbed of the Nubra river is crowned with the ruins of a fortified settlement, turned into a large palatial complex, and a group of temples. A full description of the latter is beyond the scope of this paper : we will focus primarily on the different archaeological levels visible. ${ }^{67}$

\section{Fortified settlement}

The fortified complex is composed of three parts (Fig. 19) : two clusters of buildings (A and $B$ ), and the ruins of the former protected settlement (C). The first cluster (A) constituted an outer level of defences and the second (B) an inner one.

Figure 19. Charasa : plan of the fortified settlement

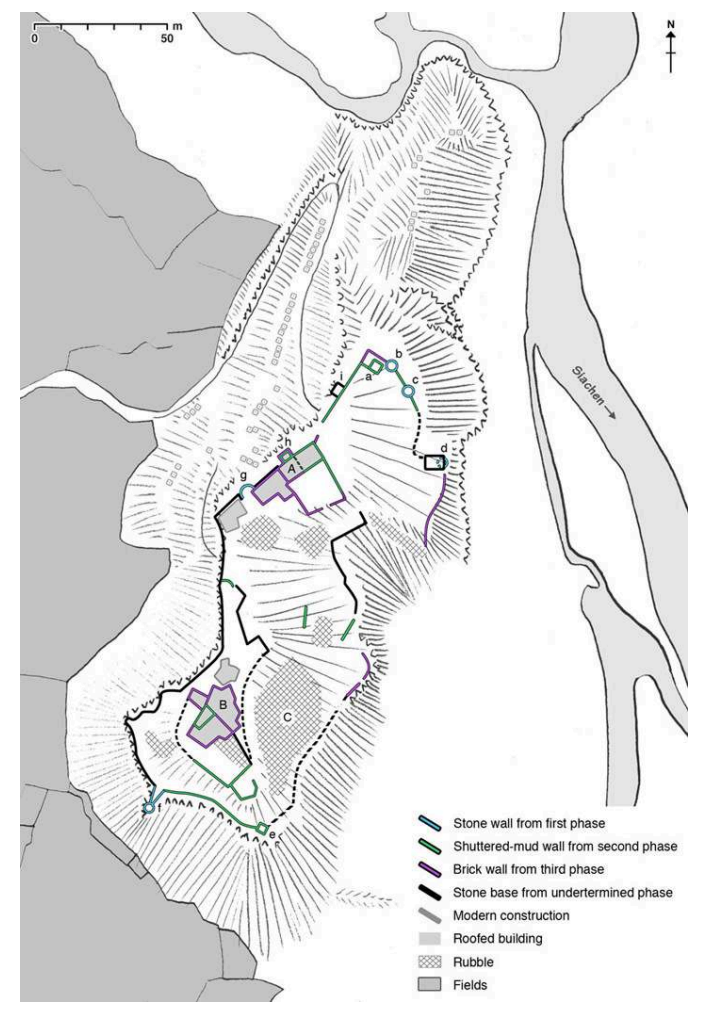

Vernier \& Devers 2014

91 Among these different parts, three main archaeological levels can be identified (Fig. 19). The first is characterised by walls built in stone masonry that follow the curves of the terrain, and flanked by round towers with elevations in bricks. The towers from this stage feature triangular loopholes that are delineated by two bricks leaning against each other. The second level is characterised by walls made in red shutteredmud. They are built either on top of levelled walls from the previous state, or on top of newly timber-laced masonries. Their loopholes are large and rectangular, moulded into the mud. The constructions from this stage are strictly rectangular. When shutteredmud walls are built on top of walls from the previous stage, they do not follow their original curves : they go straight using large timbers to bridge the turns. The third level 
encompasses several sub-stages of constructions, all characterised by tall brick walls. Like for the previous phase, the bases of the walls are built in timber-laced masonries. The loopholes, triangular, are different from those of the first stage as they are delineated by a gradual overhang of bricks. Both clusters of buildings underwent important modification during this stage : existing shuttered-mud constructions were altered - several doors and openings were walled, new parting walls were erected and extended with new brick buildings. Tower $h$ constitutes the unique example in Ladakh of a shuttered-mud tower encased by brick-walls. This feature is quite peculiar to us as it does not seem to fulfil any function.

\section{Palatial buildings}

On an artistic level, the palatial buildings incorporate decorative woodcarvings, such as capitals, doorframes and beams. One doorframe stands out for it is carved with a garuda figure on the top at the centre of the lintel : the garuda holds four snakes, two in its beak and the two other ones with its human style hands, the snakes split in two interlaced pairs going down on each side of the entrance wooden frame. Other doorframes are engraved with more common floral scrolls motifs that can be seen at various places in Ladakh on doorframes, beams and capitals. ${ }^{68}$ Among the decorative motifs on the pillars are Buddhist symbols such as the endless knot, the conch, vase and umbrella and some Lantsa lettering. ${ }^{69}$

\section{Petroglyphs}

On the northern tip of the rocky formation outside the rampart, near towers $b$ and $c$, are some petroglyphs. Except for one crude carving of a chorten they consist in ibexes. An interesting panel displays forteen ibexes, some adults and some small, well executed and with a dark patina. They have four short straight legs, an elongated rectangular body, an upward curved short tail and very long curved horns. This type of images may well be assigned to the Bronze Age.

Our exploration along the Siachen ends at Charasa. We further explored the Nubra region along the Shyok river, starting from Digar, then going down the right bank from Rongdo to Tirit.

\section{Digar}

The village of Digar is reached by a motorable track on the left bank of the Shyok.

\section{Buddhist carving}

In the village is a monumental ancient Buddhist carving now sheltered within a temple known as Chamba Lhakhang (Fig. 20)..$^{70}$ The relief, about $3.2 \times 7.1 \mathrm{~m}$, is carved on a tall boulder and depicts Maitreya : he wears a three-pointed crown, holds a decorated vase in his left hand and a rosary in his right hand. Faded paint is still visible in the headdress. Some parts of the face (nose and cheeks) are fixed with clay pasted on the rock. Some elements of the jewellery (earrings and necklace) are set with small stones, turquoises and corals, and clay. At least one kneeling donator figure is represented at 
the foot of Maitreya. The size of the relief and presence of a donator reminds us of the well-known carving of Mulbekh but a detailed stylistic analysis of Digar's Maitreya is needed before any comparison shall be made. The latter presents stylistic peculiarities such as a belt adorned with lotus petals.

Figure 20. Digar : view of the temple sheltering the monumental carving of Maitreya, and detail of the face and torso

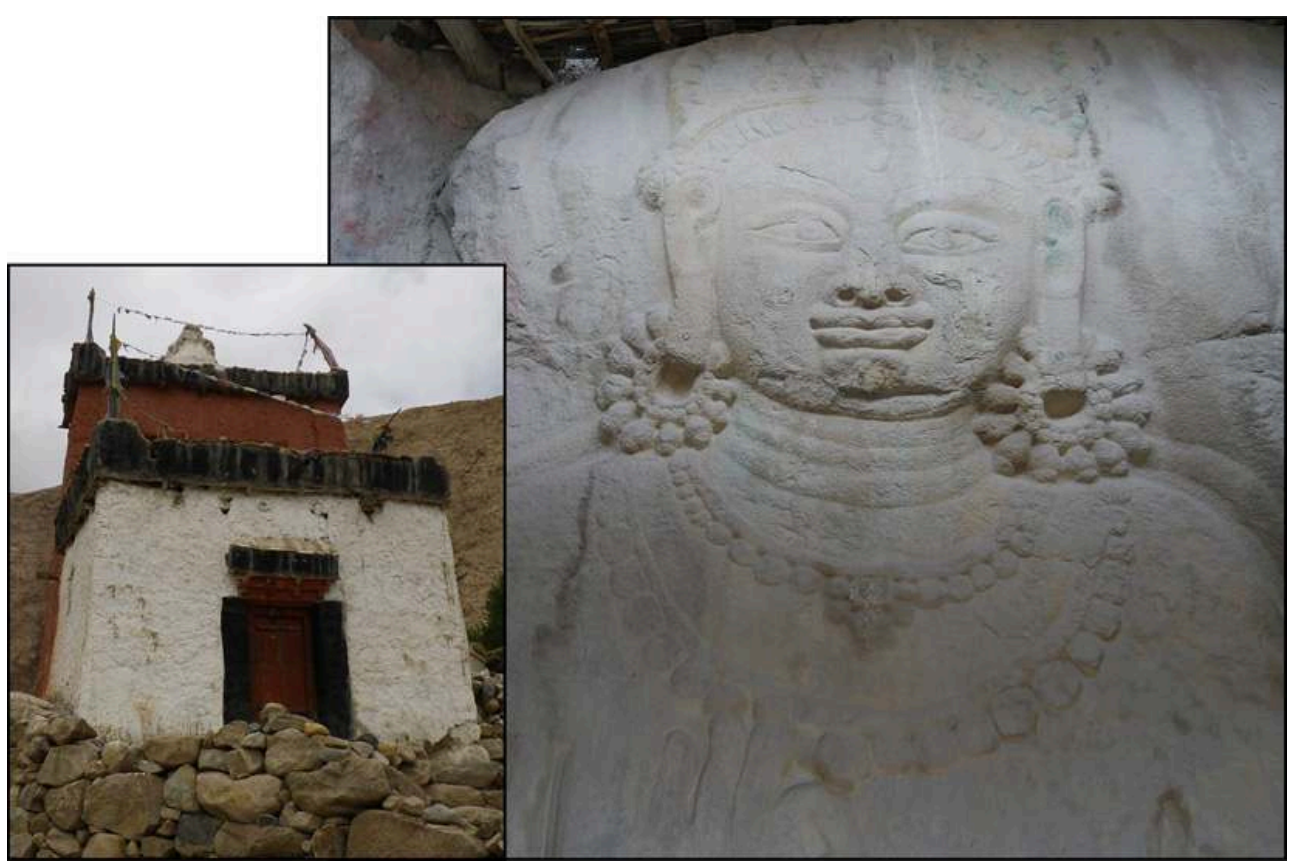

Bruneau 2014

The relief is now enshrined within a temple, which consists of three built walls while the fourth is the boulder itself. The walls are painted with rather recent murals, but the iconographic program itself could be older. The other sides of the boulder are engraved with series of om mani padme hum and with chorten designs. A chorten is built on top of the rock together with a red lhatho. Seldom boulders in the village, in proximity of the relief, bear images of chortens. Also, noticeably a crude copy of the relief is incised on a boulder at the entrance of the village, replicating the lotus pedal decoration of Maitreyas' belt.

\section{Kharpoche}

About $500 \mathrm{~m}$ away from the village into the side valley of Digar are the extensive ruins of a fortified settlement. The site is set on a steep headland overlooking the confluence of two streams. The cliffs at this confluence are pierced with numerous caves, some of them with ruined walls in front. Several are nowadays inaccessible as they are about $15 \mathrm{~m}$ above the valley floor. The site of Kharpoche is at the crossroads of the paths leading either to Sabu or to Stagmo in central Ladakh. At the eastern tip of the headland is one of the finest Buddhist stela of Ladakh. 


\section{Fortified settlement and petroglyphs}

99 walls going from one edge of the headland to the other divide the settlement in three parts. These transversal walls also act as retaining walls, creating some sorts of large terraced levels. A number of rooms are quadrangular, and others are organic in shape. The masonries are made of large mud-mortared cobbles. The two upper parts of the settlement are organised around large open squares. Ceramic shards are abundant. Several boulders are engraved with petroglyphs, including the depictions of a chorten and of a duel scene.

\section{Buddhist carving}

In proximity of the settlement we documented a tall (4.1m in height), free standing stela, bearing Bodhisattvas on its three sides (Fig. 21$).{ }^{71}$ One $(2.6 \times 4.1 \mathrm{~m})$ is carved with a depiction of Mañjuśrī and Tārā; another $(1.4 \times 4.1 \mathrm{~m})$ with Vajrapāṇi and the third $(1.6 \times 4.1 \mathrm{~m})$ with Padmapāni. The headdresses, jewellery and garments of the Bodhisattvas are varied. The space between the figures is filled with floral decoration and makaras, so far unique features for the Buddhist carvings of Ladakh.

Figure 21. Digar Kharpoche : the three sides of the Buddhist carving at the edge of the fortified settlement (height is $4.1 \mathrm{~m}$ )

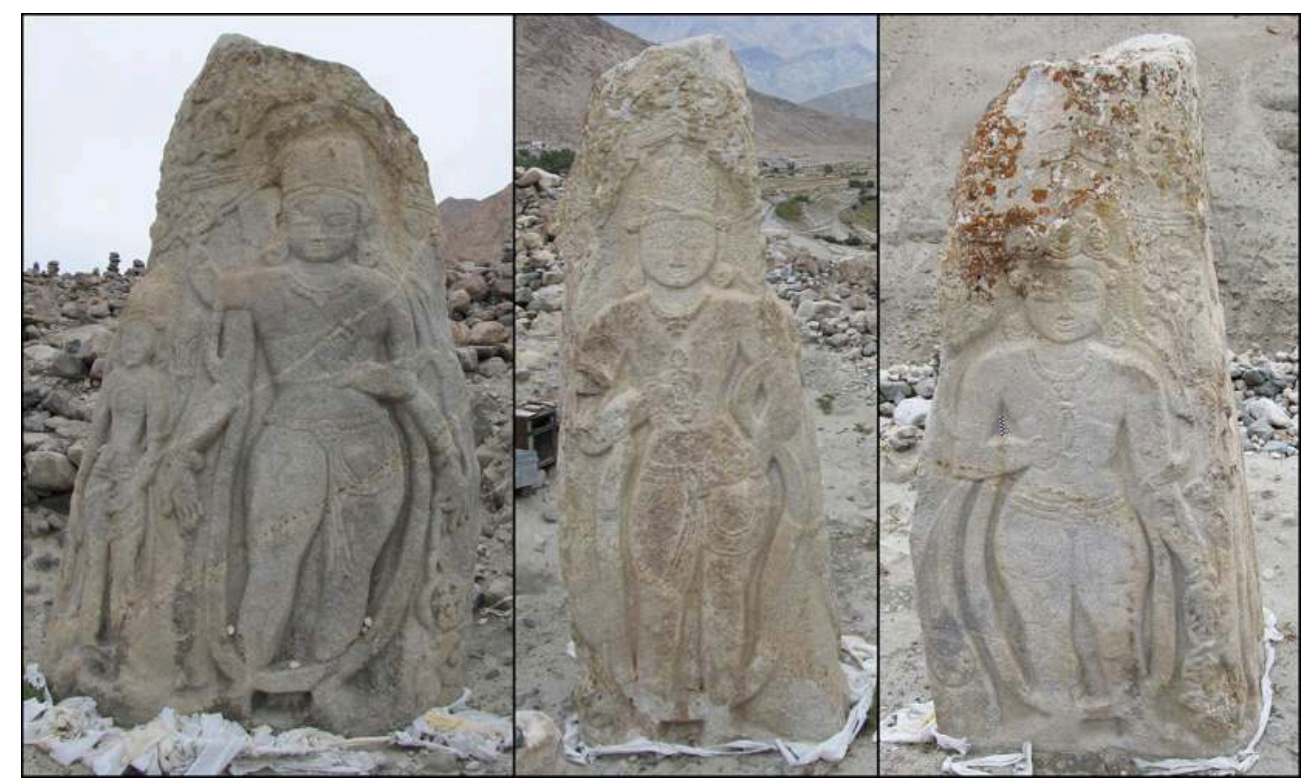

Devers 2014

\section{Rongdo ${ }^{72}$}

Rongdo is the last village accessible by road on the right bank of the Shyok when coming from Tirit. Between Rongdo and Tsati one comes across an alluvial fan. At its bottom is the fourth footprint of Dachompa Nyima Gungpa in the Nubra region..$^{73}$ As it is the case in Tirisa, Ensa and Murgi, a small structure was built to shelter the print.

Études mongoles et sibériennes, centrasiatiques et tibétaines, 46 | 2015 


\section{Petroglyphs} . Above the village, a large rock that is still the object of worship bears four figures standing in a straight samabhanga posture. One should notice the quadrangular holes on top of the figures, used for beams either for roofing or scaffolding. The central deity represents Maitreya $(2.66 \times 6.60 \mathrm{~m})$ identifiable by the chorten in his crown, the rosary and the water pot. He is framed on his right by Mañjuśrī (1.97x5.44m), holding the sword and the book, and, on his left, by a Buddha $(1.26 \times 3.30 \mathrm{~m})$ and a Bodhisattva $(1.26 \times 2.54 \mathrm{~m})$. The four figures display similar stylistic traits such as round faces, elongated eyes, broad shoulders, long and wavy fingers. They wear a tight and specific dhoți : the two legs are distinct and joined by a triangular shape. Mañjuśrī and Maitreya display a jeweled belt and their waist is marked by four circular forms that are also found on the Buddha image. The garland and central fold of Maitreya's dhoți are noticeable for their floral and geometric decoration. There are traces of red paint on the relief. 
Figure 22. Tirit : line drawing of the Buddhist carving viewed from the southwest

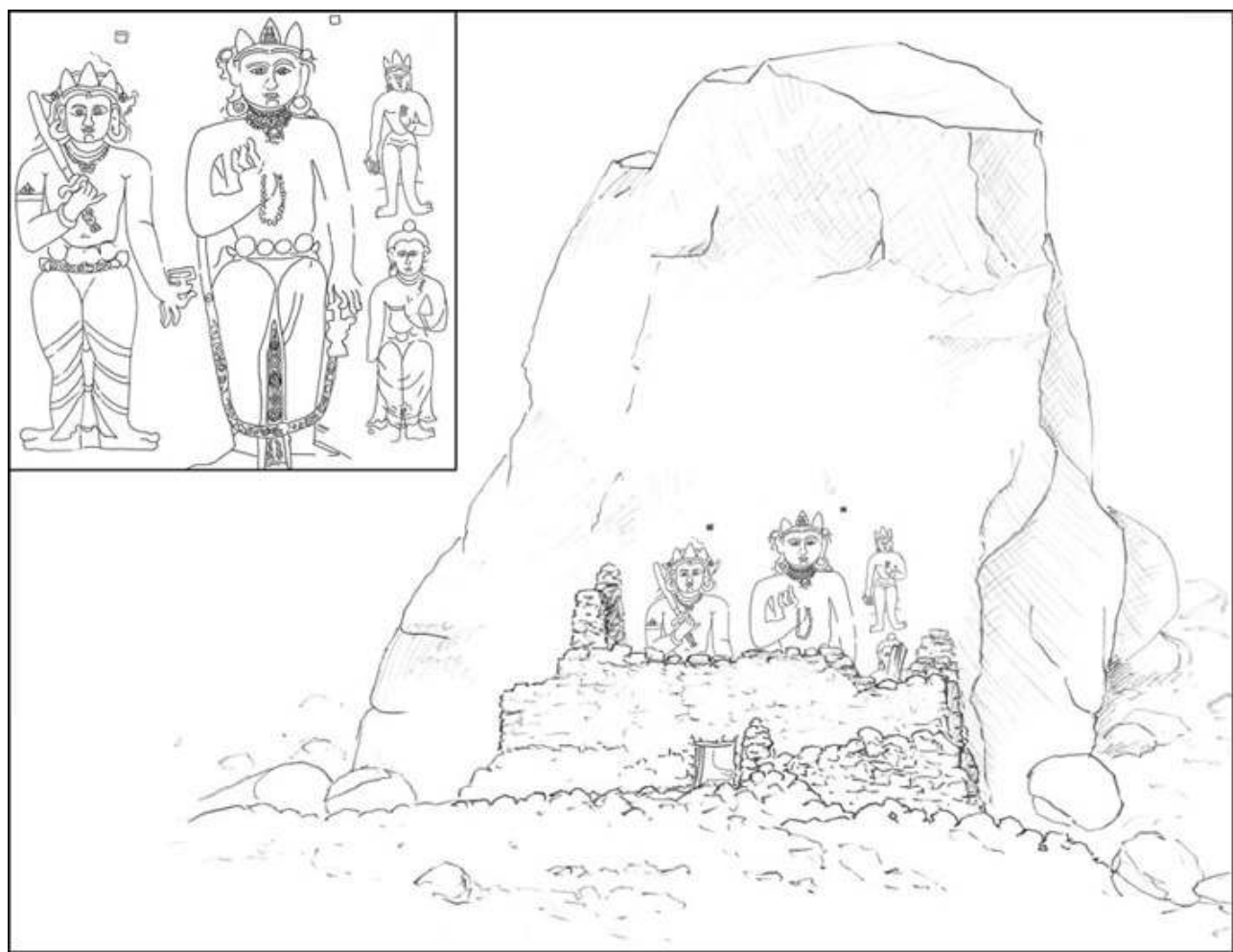

The rock is $14 \times 12 \mathrm{~m}$, the carved area $6.2 \times 6.6 \mathrm{~m}$. From left to right : Mañjuśrī, Maitreya, Buddha (bottom) and a Bodhisattva (top)

Vernier 2008

Until recently three walls delineated a small room with an entrance door in front of the relief. The ground in this room, the level of which had increased over time, covered the lower part of the figures. Also, a circumambulation path around the rock was clearly identifiable. However, in early spring 2013 the Tourism Development Authority dismantled the walled structure, leveled the ground and created a stone and cemented plinth in front of the rock, along with a rather disproportioned car parking area, destroying, in addition to the charm of the site, any evidence that may have been retrieved from proper archaeological investigations.

\section{Petroglyphs ${ }^{75}$}

A few hundred meters further down the relief, on both sides of the road, are about five engraved boulders. Aside ibexes are the large carving of a chorten and a hunting scene composed of two bowmen chasing yaks.

Crossing the Shyok river we carried on our exploration on its left bank at Deskit, wellknown for its picturesque monastery. 


\section{Deskit}

110 The monastery of Deskit is currently located on the premises of an ancient fort. ${ }^{76}$ According to the villagers it was formerly located on the small hill now occupied by a monumental Maitreya statue consecrated by His Holiness the Dalai Lama in 2010.

\section{Deskit Gonpa : the former fortification}

Since the fort was largely altered by the shifting of the monastery on these premises, its full study and exact mapping would be a vast undertaking. Our survey instead aimed at identifying the main archaeological levels.

The lowest and most ancient level is made of walls in stone masonry with timberlacing. Above these, forming the second level, remnants of shuttered-mud walls are visible in different places. Only few walls or fragments of walls from this level are left, which, combined with their state of conservation, suggests that the fortress from this period underwent an event or a series of events during which it got seriously damaged. Finally, in the posterior levels walls are mostly built in bricks. The sequence of these levels is thus similar to that observed in Charasa. The main difference being that original walls do not feature timber-lacings in the latter location.

113 The last untouched remnant of the fortification is a round tower above the monastery ${ }^{77}$ (Fig. 23). Still roofed, to our knowledge it is the only tower of this shape such preserved in Ladakh. It is quite large, over $8 \mathrm{~m}$ in diameter, with eight loopholes. A central Ushaped wall supports the timbers of the roof, which are laid in a radiant fashion. The tower borders a very steep slope on its north-western side, making it a difficult angle for an attack. A fosse about $4 \mathrm{~m}$ wide and $1.5 \mathrm{~m}$ deep was dug on its more vulnerable south-eastern side. 
Figure 23. Deskit : tower and former fort seen from the northeast. The close-up view of the tower is taken from the southwest

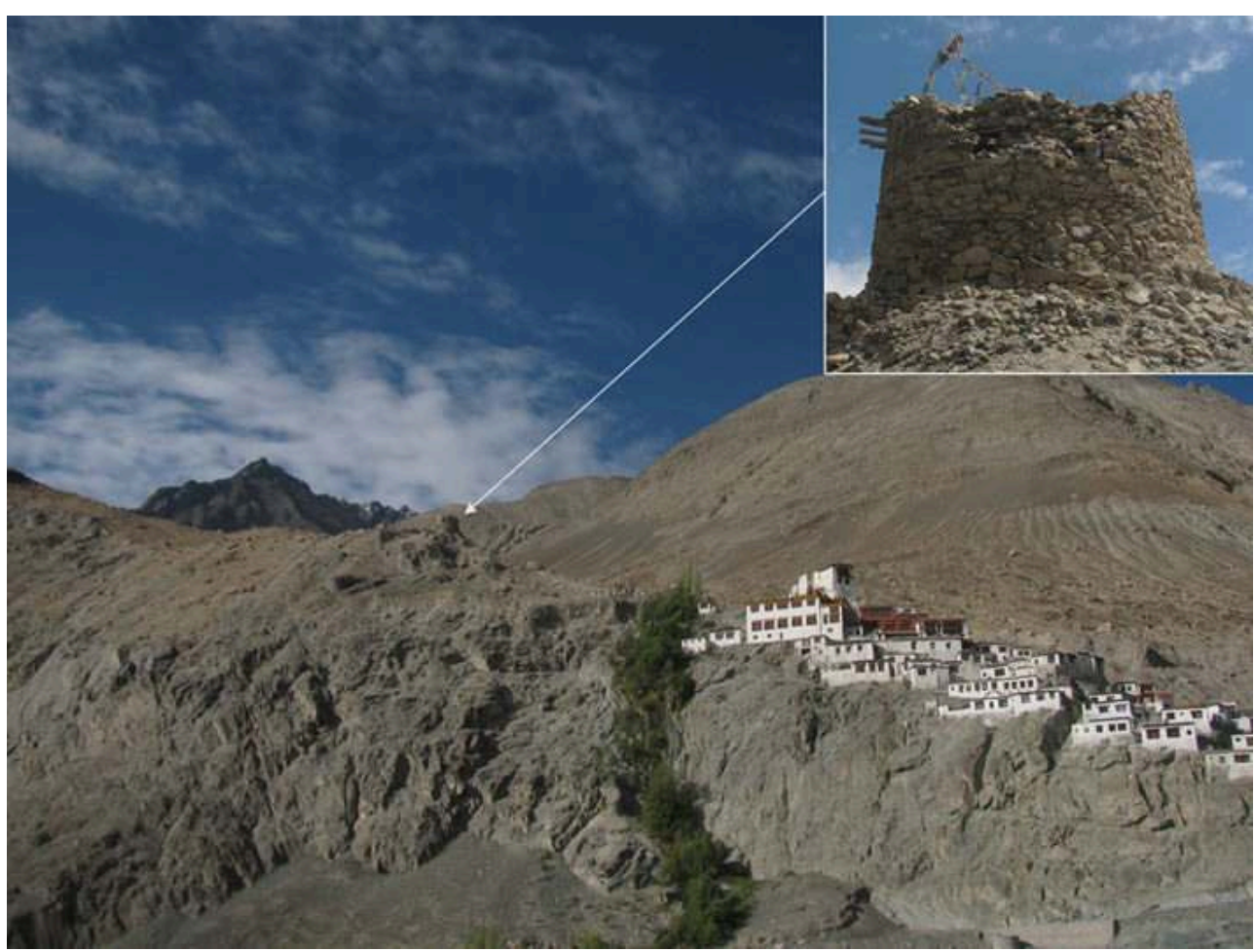

Devers 2010

\section{Buddhist carving}

114 A slab $(3.85 \times 1.60 \mathrm{~m})$ enclosed within three ruined walls is found below the monastery ${ }^{78}$ (Fig. 24). It bears a representation of a two-armed Maitreya and a four-armed deity with the lower hands in añjalimudrā. The two deities wear similar round earrings and necklace as well as a plain garland. Noticeable are the ribbons on each side of their heads. On one of the remaining walls are traces of a red painted diagram. 
Figure 24. Deskit : Buddhist carving from the north and close-up view (The slab is $3.85 \times 1.6 \mathrm{~m}$ ). Left : Maitreya and right four-armed deity

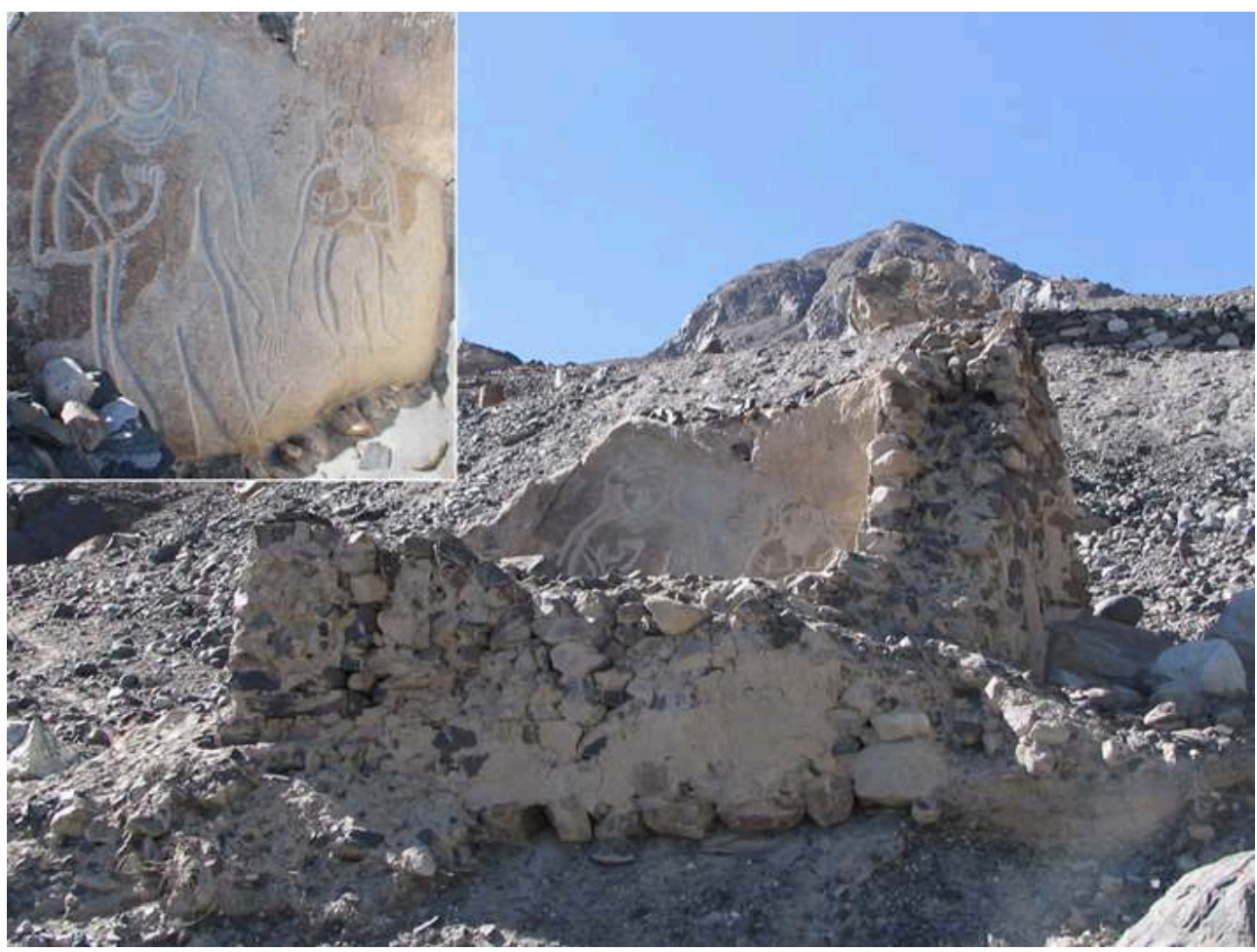

Bruneau 2006

\section{Chomo Phu Lhakhang : temple and petroglyphs}

115 In the side valley of Deskit, about half an hour of walk behind the monastery, is a small temple. ${ }^{79}$ After going up in the mountain, a small footpath ending with two ladders goes down a cliff before reaching a small patch of vegetation along a torrent. The shrine is very small $(2.1 \mathrm{x} 1.9 \mathrm{~m})$, the roof is low $(1.8 \mathrm{~m})$, the door both narrow and low $(0.7 \mathrm{~m}$ wide, $0.9 \mathrm{~m}$ high). The walls, made of stone, are $50 \mathrm{~cm}$ wide. Only the murals of the right and entrance walls are still preserved (Fig. 25) - the other two were fully replastered during a recent renovation of the building. About half of the original roof - made in wood, possibly formerly painted - is still there, while the other half was rebuilt with stone slabs during the restoration. It can be noted that beside grey and black, the last pigment preserved on the walls is red, giving a particular red tone to the murals. According to Martin, the paintings point to a late 14th or early 15th century dating ${ }^{80}$.

The cliff bordering the site is engraved with numerous petroglyphs from various periods. The variety of motifs extends from zoomorphic depictions, anthropomorphic ones, chortens, to inscriptions (in Tibetan and Latin scripts). 
Figure 25. Deskit Chomo Phu Lhakhang : detail of the murals

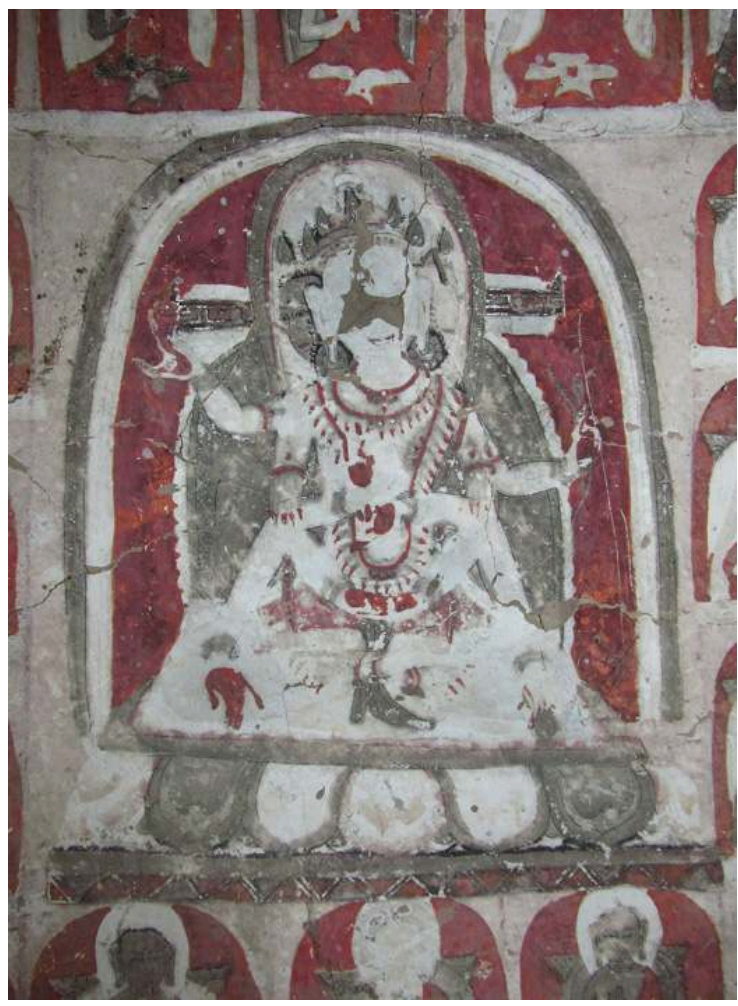

Devers 2014

\section{Tingang complex}

117 On the other side of the torrent bordering the monastery extends a plateau, at the other end of which are a series of ruins, locally known as Tingang. The ruins consist in: three groups of habitations, three temples, a row of chortens, and a strongly built house (Fig. 26). 
Figure 26. Deskit Tingang : general view from the south

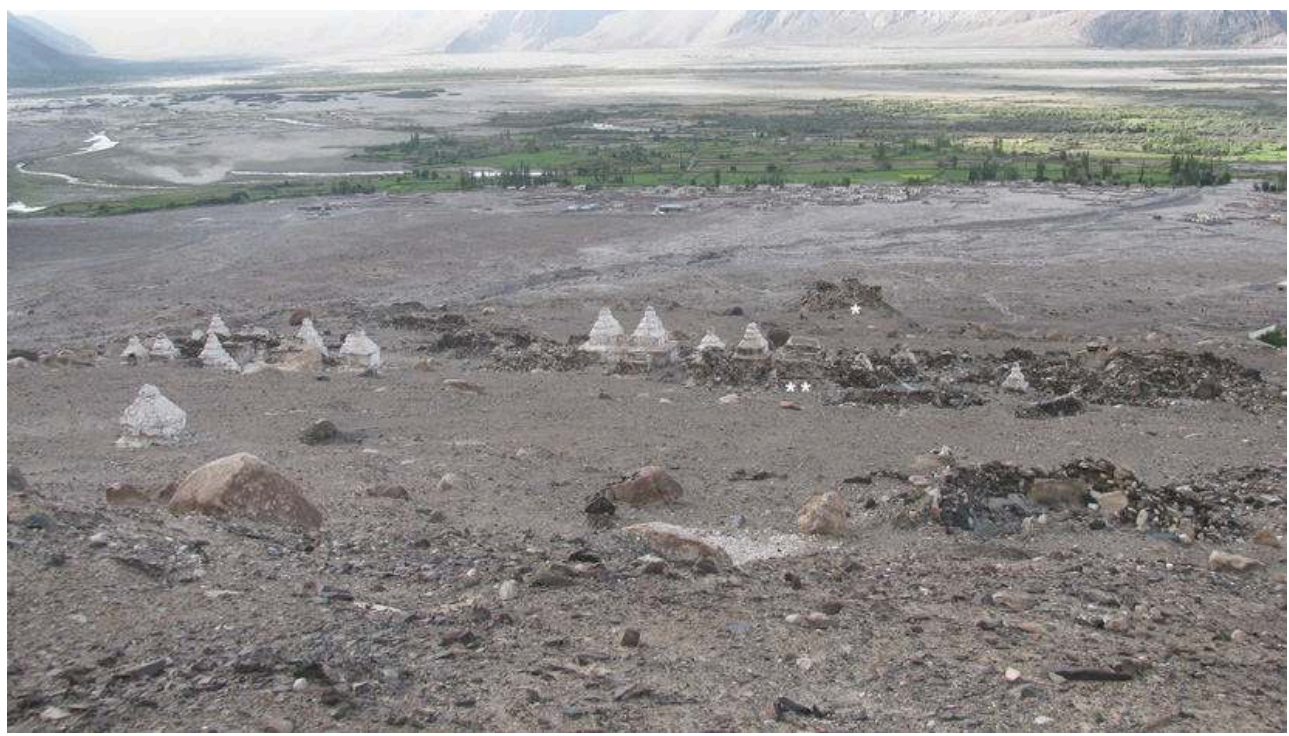

The single white star indicates the strong house ; the three temples are lined behind the two white stars

Devers 2010

The rooms of the habitations, overall rectangular, are of an average size of $3 \mathrm{~m}$. The walls, built in a schist-like masonry, are preserved on an average height of about $1.5 \mathrm{~m}$. No timber is left. Several buildings are made of series of rooms, something not encountered in the other ruined settlements described in Sumur, Khyagar, Panamik or Murgi, where the buildings are made of single rooms. Walls often incorporate niches. The state of conservation is rather good and the buildings do not seem to have undergone any particular type of destruction other than the natural decay of time. Ceramic is abundant, we noticed one shard with painted design and two with incised motifs.

119 Turning now to the temples : they are very small in size (Fig. 27). Temple 1 measures $1.7 \times 1.8 \mathrm{~m}$, and its walls are $1.7 \mathrm{~m}$ tall. The doorway is about $70 \mathrm{~cm}$ wide, the former lintel was about $90 \mathrm{~cm}$ above the ground. The walls are made in mud-bricks (the size of which is not measurable because of the coat) except for the entrance wall built in schist-like masonry. It is built on a raised platform with a flight of six stairs. The inner back wall still bears the mud-halo of a statue, about $115 \mathrm{~cm}$ in size (Fig. 28). There is no trace of holes or sticks in the wall, indicating that the statue must have been free standing. Temple 2 is larger $(2.2 \times 2.5 \mathrm{~m})$, with a doorway similar to temple 1 (70 $\mathrm{cm}$ wide) - however it is not possible to know the height of the former lintel. Its walls, $1.9 \mathrm{~m}$ tall, are built with a schist-like masonry. As most of the coat of the back wall has fallen off, it is not possible to know whether there was a halo as in temple 1 . The space between temple 1 and temple 2 is filled with bricks. Temple $3(1.7 \times 2.0 \mathrm{~m})$ is built against temple 2. Its right wall is actually the left wall of temple 2. Its doorway is narrower $(60 \mathrm{~cm})$ than the other two temples, and the former lintel was about $90 \mathrm{~cm}$ above the ground. The walls are $1.7 \mathrm{~m}$ tall and built with a schist-like masonry. The mud-coat also mostly fell off, but some shape painted in red can still be seen on the left wall. There is a walled courtyard in front of the temples, in the middle of which stands a tsakhang with numerous clay tablets of different types. Behind the temples is a row of several chortens. 
Figure 27. Deskit Tingang : plan of the three temples

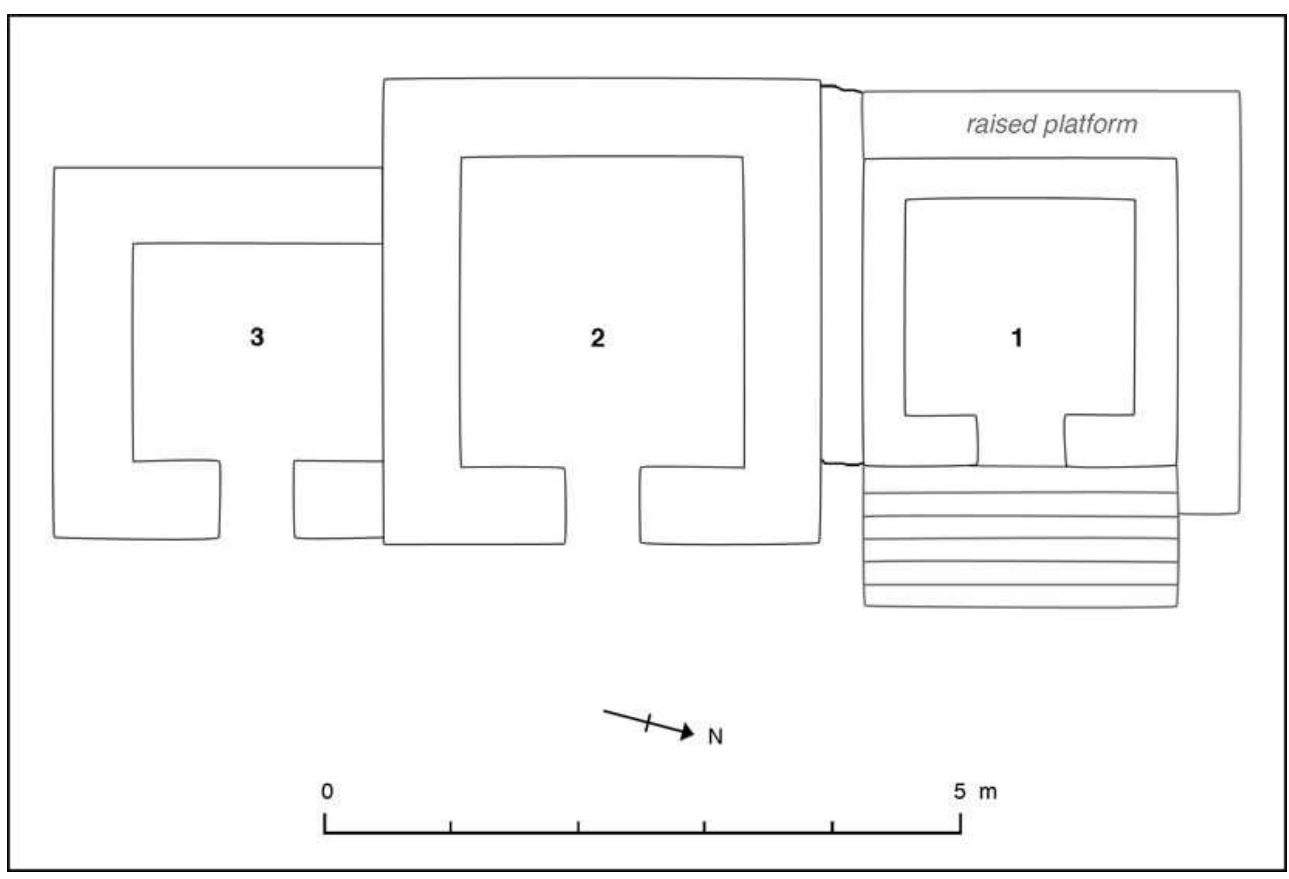

Devers 2010

Figure 28. Deskit Tingang : temple 1 (right, in bricks) \& 2 (left, in stone) viewed from the east

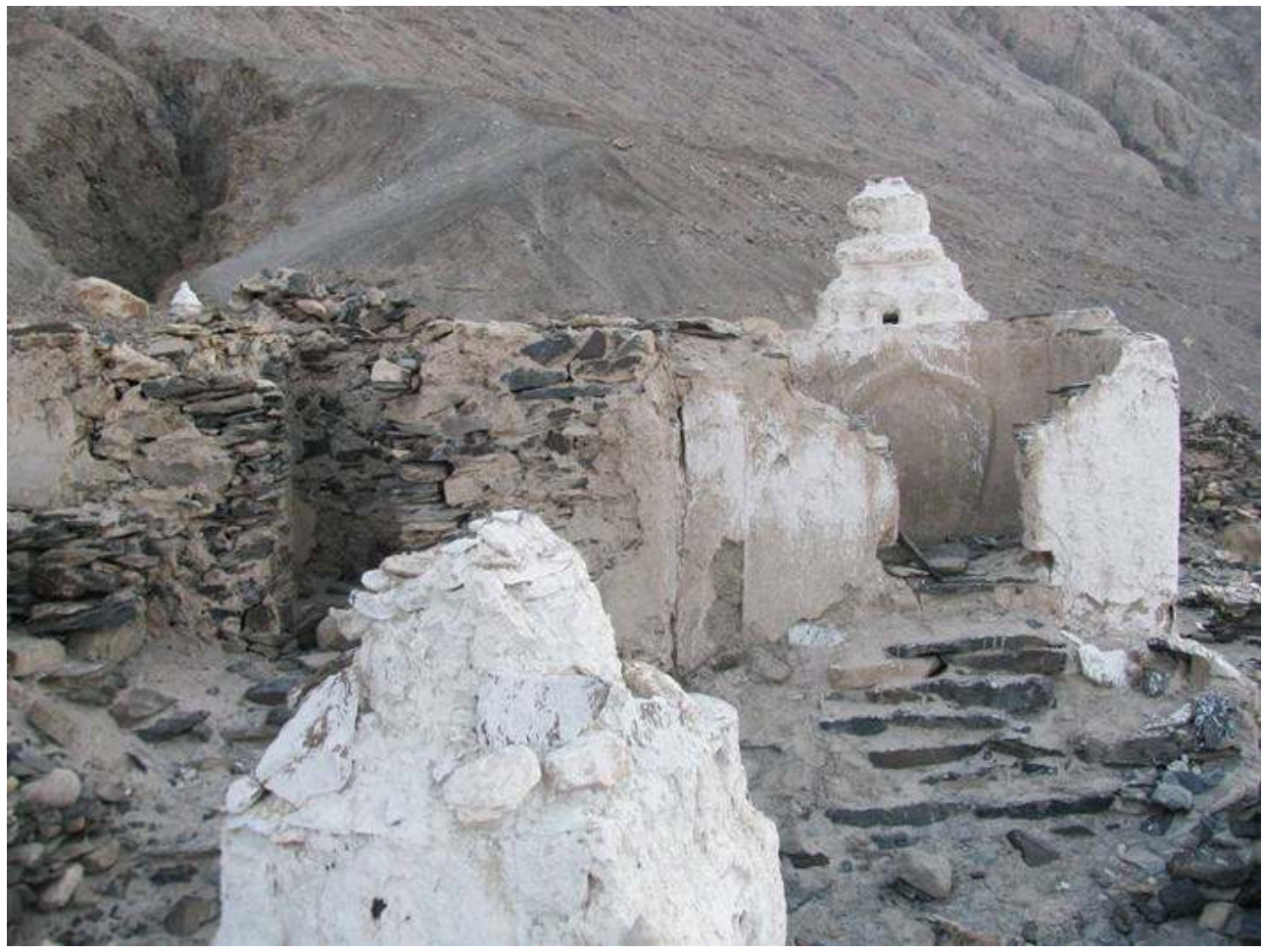

Devers 2010

The absolute dating of these temples is difficult to ascertain, as the main elements that could have been of help, i.e. the murals, are gone ${ }^{81}$. However, their simple plan with no 
porch, recess or projection; the reduced size of their rooms; the low height of their walls; and the reduced width and height of their former doors make them the smallest and shortest ruined temples of Ladakh. These characteristics are very similar to those of the Chomo Phu Lhakhang located in the side valley behind the monastery. Considering the rarity of such attributes - which are seen only in these three temples and in the Chomo Phu Lhakhang - and the fact that these attributes are met only in Deskit - nowhere else in Ladakh are there such temples or ruins of temples -, it can be hypothesized, in the absence of chronometric data, that the three temples in Deskit Ting gang may be of a similar period as the temple in Chomo Phu, i.e. from around the late 14 th or early 15 th century.

Considering the size and layout of the buildings in the various groups of habitations (i.e., several are made of series of rooms), the unusual number of niches in the walls and the presence of the temples, the ruins of Ting gang may be that of an ancient Buddhist compound.

Away fromthe rest of the settlement, to the north, is a kind of 'strong' house. We do not use the word 'fortification' because its location is not particularly defensive - especially in Ladakhi standards of high and precipitous topography - and its size is rather limited. It consists of a rectangular building divided in three, rather small (between $1.3 \mathrm{~m}$ and $2.3 \mathrm{~m}$ in width and $2.7 \mathrm{~m}$ in length) rooms. The walls are $60 \mathrm{~cm}$ thick and $1.8 \mathrm{~m}$ tall. The few cobbles on the ground suggest that it was likely their original height. It does not seem that there was any opening other than the door. The masonry uses very little to no mortar. A protective enclosure runs around the building, over $2 \mathrm{~m}$ in height with a thickness at the base of nearly $1 \mathrm{~m}$ that decreases vertically. It is not possible to identify the function of this building (habitation, religious usage, etc.) and, in the absence of chronometric data, it is difficult to venture its relationship with the rest of the Buddhist compound. The building could for instance be understood both within a Buddhist and a non-Buddhist context. Indeed, the rest of the plateau extending towards the present-day monastery of Deskit is scattered with a large number of graves of various types.

\section{Funerary site}

The main visible concentration of graves, about a hundred tombs, is located south of the ruined temples. They appear to have been looted in ancient times, like the ones documented above Panamik.

From a ground observation, they consist for the most part in rectangular or circular arrays of stones set into the ground. Rectangular graves are the largest, varying from roughly $3 \mathrm{~m}$ to nearly $10 \mathrm{~m}$ in length. Circular tombs are smaller, extending from roughly $2 \mathrm{~m}$ to around $4 \mathrm{~m}$ in diameter. At least one grave has a double-course enclosure. In the pits of several graves an underground wall, located one to two meters below the surface, corresponding to the funerary chamber is visible (Fig. 29). The graves in this part of the plateau seem to have been somewhat spatially organized : the largest tombs are found on the western edge of the area, whereas the smallest ones appear to be lined on the eastern edge. Furthermore, graves tend to follow a grid pattern that is almost aligned on the cardinal points. On the rest of the plateau, tombs are more sparsely scattered, with no immediate apparent organisation. Ceramic is rather abundant on the ground. 
Figure 29. Deskit Tingang : one of the graves viewed from the southeast. The upper line of stones is about $5.6 \mathrm{~m}$ long

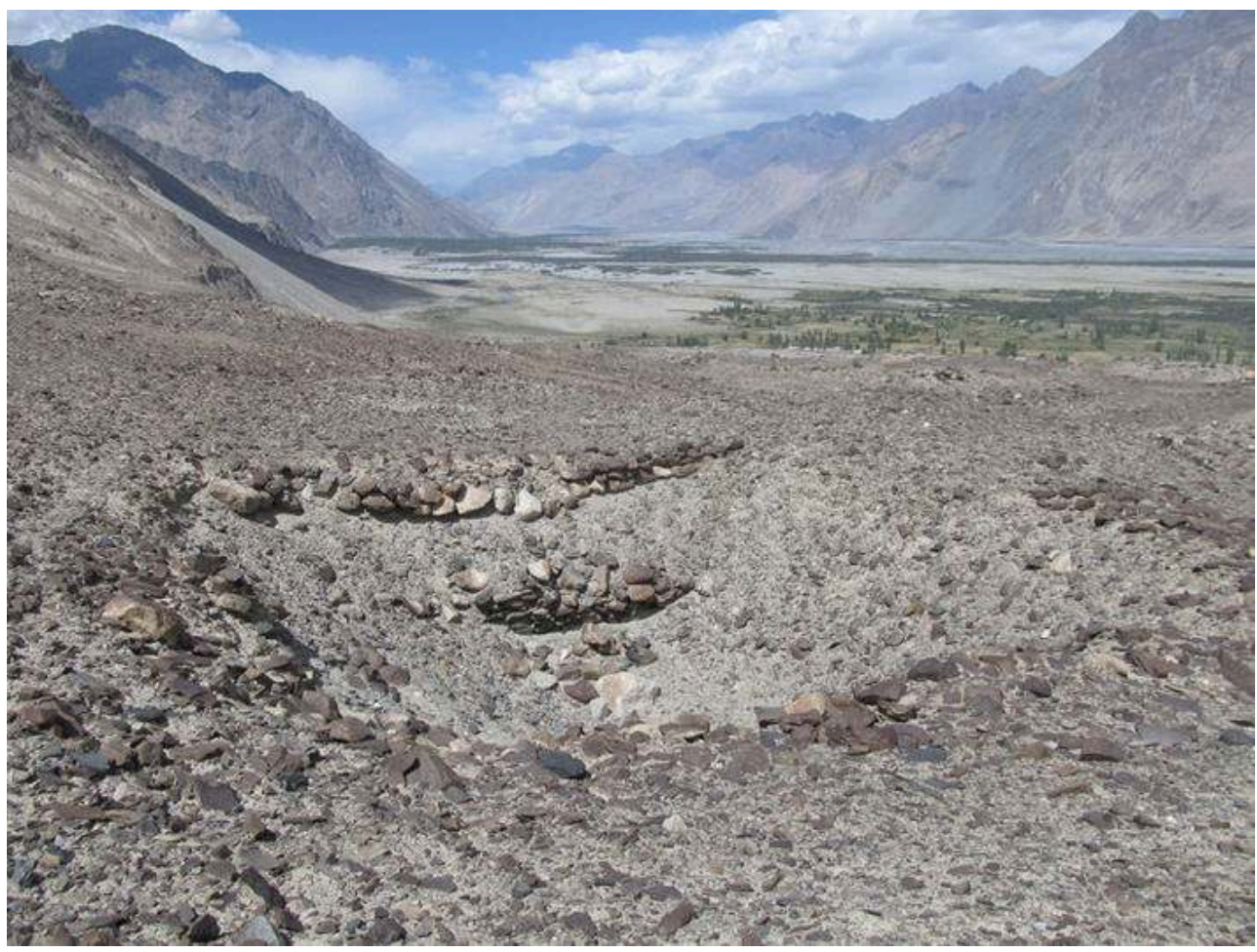

Devers 2011

Like in Panamik, from their apparent type (quadrangular and circular arrays of stones set into the ground), these graves are reminiscent of those found in Western Tibet and across Central Asia that are dated from the Bronze and Iron Ages. This dating might well be supported by petroglyphs found in proximity, at the bottom of the plateau.

\section{Petroglyphs}

The carvings are located on the surfaces of a rocky ridge, along the modern road, on top of which are several recent cremation platforms (ro khang). ${ }^{82}$ Apart from recent scratches of letters and chortens as well as a surface engraved with a series of faint animals, riders and hands, the rock art site of Deskit is remarkable for the presence of a dozen of images in the 'animal style', also known as 'art of the steppes'. Ibexes and felines are represented as if standing on the tip of the hooves, their body respectively marked by a motif in shape of a S or by stripes (Fig. 30). These thematic and stylistic characteristics may point to an Iron Age date. 
Figure 30. Deskit Tingang : recording on a transparent sheet of an ibex and a feline figures represented in the so-called "animal style of the steppes"

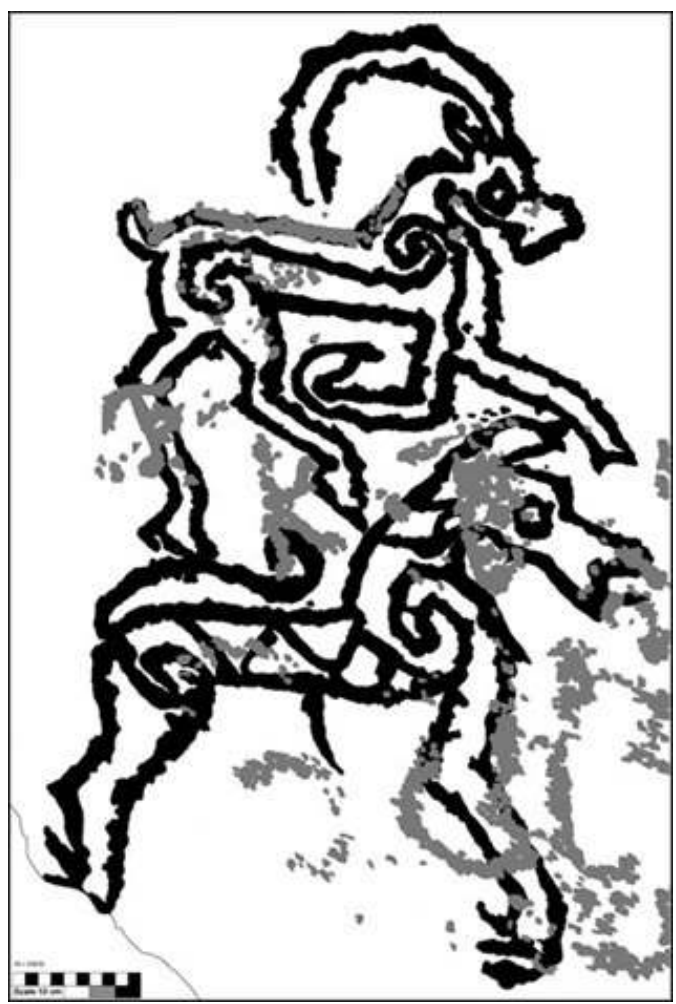

Bruneau \& Vernier 2011 \& 2014

\section{Hundar}

The village of Hundar is nowadays well-known because it is adjoining sand dunes illustrative of the landscape of the Nubra. The only known inscriptions referring to local rulers for the region, found on votive plates, were discovered there. ${ }^{83}$

\section{Fortified settlement}

The former fortified settlement of Hundar lies on a hillside along the right bank of the stream. ${ }^{84}$ The southern side is protected by a long rampart that runs downhill, flanked by eight to nine towers. Its eastern and northern flanks are protected by series of natural cliffs, complemented by small portions of ramparts and four smaller tower-like constructions. The rampart on the southern side has a general thickness of $1 \mathrm{~m}$ at its base, with a decreasing profile. Its height varies depending on the topography. Some sections are pierced with triangular loopholes. Except for the top-most tower (tower A) which is D-shaped, the towers on the southern flank are quadrangular, ranging from $2.4 \mathrm{~m}$ to $5.5 \mathrm{~m}$ in size and built in stone masonry. The actual hilltop is further ahead of tower A, and is covered with rubbles - perhaps a former tower ? Due west, on the other side of a thalweg, is a quadrangular outpost built in shuttered-mud. It seems to have had a former upper elevation in brick, but only few traces are left.

The main entrance of the settlement is located on the southern side. ${ }^{85}$ The rampart there is quite thicker, $2 \mathrm{~m}$ instead of $1 \mathrm{~m}$. A smaller more discreet entrance is located in 
the cliffs on the north-western side. The area where the actual habitations must have been is completely in ruins, only piles of rubble cover the slope. Two temples still stand among the ruins: Lhakhang Marpo and Lhakhang Kharpo. As their names indicate, their façades are respectively painted in red and in white. ${ }^{86}$

The votive plates bearing the names of local rulers were found on the mani wall at the bottom of the cliffs. ${ }^{87}$ Down below the mani wall, on the right bank of the stream, is a large boulder bearing two Buddhist deities.

\section{Buddhist carvings ${ }^{88}$}

131 The boulder, probably of granite, is in an advanced state of decay (Fig. 31). However a seated Bodhisattva $(2.37 \times 2.83 \mathrm{~m})$ holding a flower, probably Avalokiteśvara, and a Buddha $(0.92 \times 1.40 \mathrm{~m})$ seated on a lotus ( 8 or 9 downwards petals) can be identified. There are remains of red paint and the boulder is still the object of worship. According to the villagers, a larger sculpture existed just opposite, on the other side of the stream, but was destroyed about 30 years ago when the powerhouse was built. ${ }^{89}$

Figure 31 . Hundar : Buddhist carving. The main visible Buddha is $2.37 \times 2.83 \mathrm{~m}$

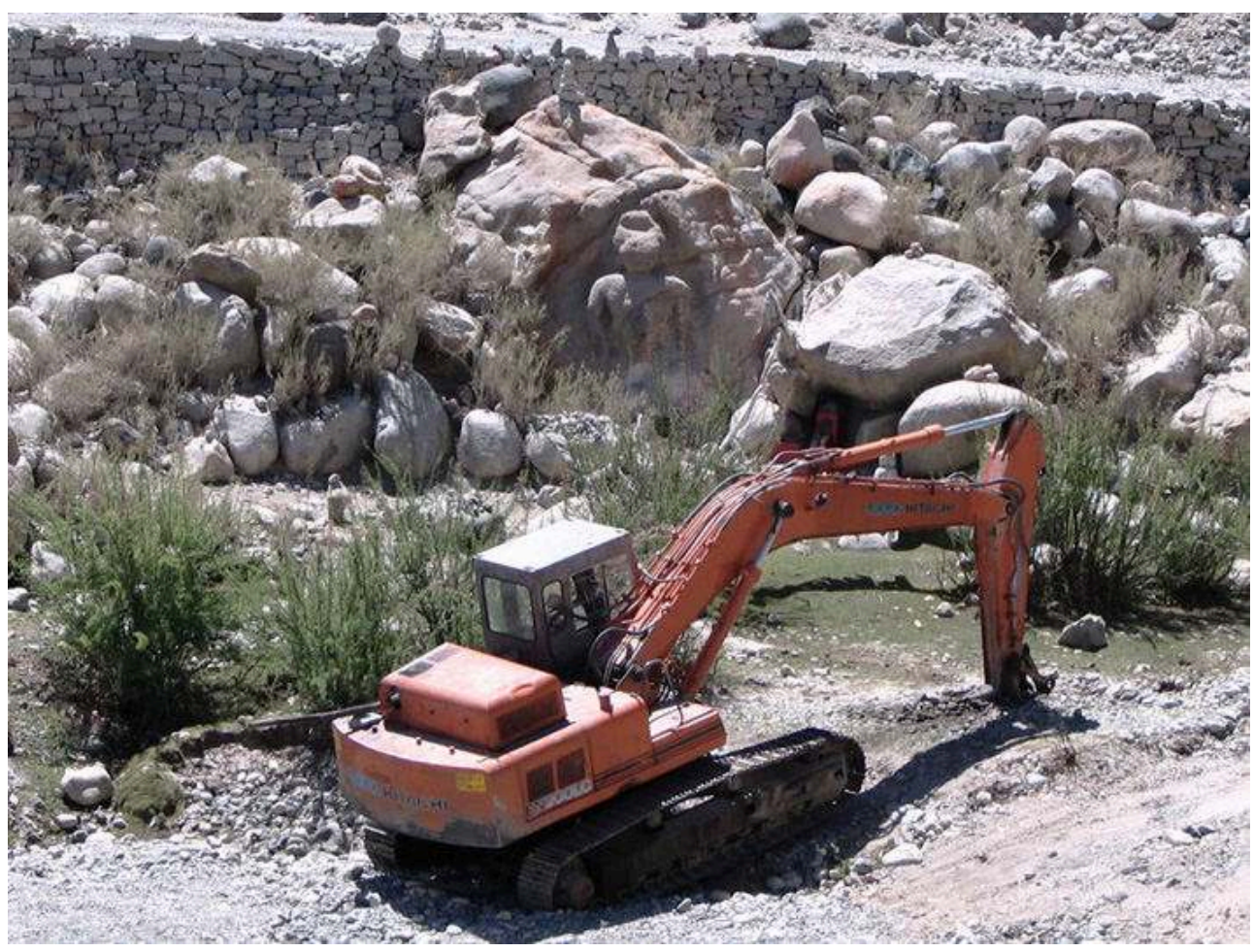

Bruneau 2011

\section{Hundar Brog}

Hundar Brog is the name given to the side valley of Hundar. It leads to Central Ladakh, either to Phyang through the Lasirmo pass, or to Basgo through the Nia pass. Guided by former reports from the $\mathrm{ASI}^{90}$ and the identification of an ancient fortified settlement 
on a satellite image by a colleague ${ }^{91}$, our survey conducted in the valley proved very fruitful.

A few kilometers from the valley's mouth is a large cave. About ten chortens painted in ochre on the outer rock surface were documented. A few kilometers upstream, the valley widens and opens onto ancient terraces, where there is an abandoned Buddhist complex. It is formed of a group of chortens and ruined buildings dominated by five caves, some interconnected, one with remnants of murals.

\section{Fortified settlement}

Few hundred meters away, at the junction of two streams, the ruins of an ancient fortified settlement crown a steep headland overlooking the confluence. The topographical setting is quite similar to that of Kharpoche in Digar. This promontory is unfortunately too steep and dangerous to climb but its surroundings were the source of interesting discoveries. On one edge of the complex, we found significant traces of metallurgical activities in the form of slags, some incorporating fragments of pottery. From what we could see, the masonries are similar to those observed in Kharpoche, i.e. they are made of large mud-mortared cobbles.

\section{Buddhist carvings}

135 Around the fortified settlement we documented three large Buddhist reliefs of Bodhisattvas (Fig. 32), one accompanied by worshippers. The general outlook and iconography of these bas-relieves match those at Tirit and Khyagar. The smallest $(1.60 \times 2.15 \mathrm{~m})$, and most faded one, is engraved on a boulder located at the entrance of the ruined fortified settlement. A three pointed crown, large circular earrings and a probable abhayamudrā are still visible. A second relief (c. $2.6 \times 3.8 \mathrm{~m}$ ), carved on a large boulder, stands at the confluence of the streams. It is the most elaborated of the three. It represents a four-armed Avalokiteśvara (vase, rosary and antelope skin on the shoulder) surrounded by four worshippers, some of them kneeled. The third relief (c. $2 \times 5 \mathrm{~m}$ ) is situated on the other side of the main stream, west of the fortified settlement, next to the location where a bridge might once have stood to access the site. It is coarser than the others. It was carved directly on the cliff of the mountain. It also bears rosettes, large earrings, a three-pointed crown and is in abhayamudrā. Some parts of the figure, mainly its head, have been modeled with clay pasted on the rock surface. A similar practice was observed on the Buddhist slab of Deskit and on the monumental Maitreya at Digar. The contemporaneousness of this application is apparently asserted by some very faded remains of color on some clay elements. The spatial disposition of these three figures is quite interesting, as they seem to function as protective figures to guard the accesses of this crossroad, fortified, site. 
Figure 32. Hundar Brog : the three Buddhist carvings (from left to right : $1.60 \times 2.15 \mathrm{~m}, 2.6 \times 3.8 \mathrm{~m} \&$ c. $2 \times 5 \mathrm{~m})$

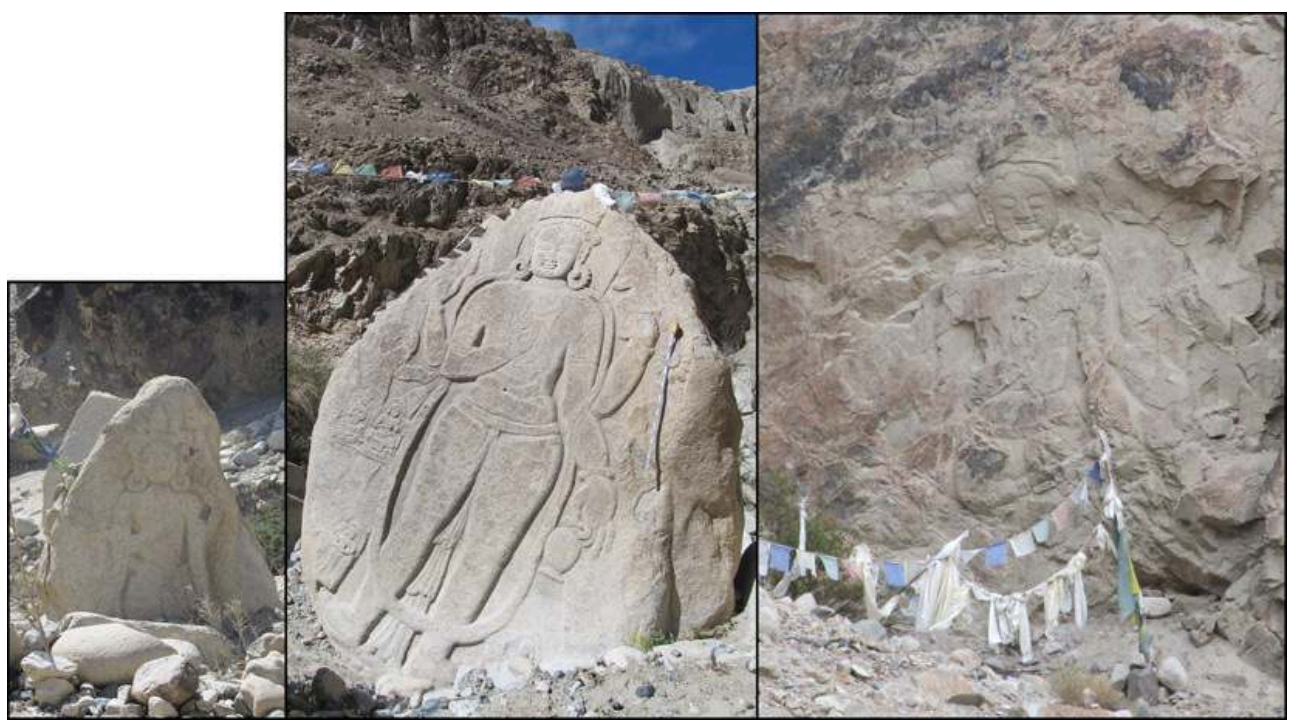

Devers 2013

The fortified settlement of Hundar Brog strongly reminds of the fortified settlement of Kharpoche. Without any necessary chronological implications, both sites are found on similar flat headlands at the confluence of two streams; both are built inside side valleys with easy passes leading to central Ladakh; both are built with similar masonries and both are characterised by finely sculpted Buddhist carvings located at their edges. These two sites form as such a particular group, distinct from the other fortified settlements we have inventoried so far in Nubra and in Ladakh in general.

\section{Skuru}

Skuru is the last Buddhist village on the left bank of the Shyok. Shortly before the village, about a kilometre before the bridge, is a large boulder (c. $6 \times 6 \mathrm{~m}, 3 \mathrm{~m}$ high), in the middle of a field on the right side of the road, with Buddhist deities carved on it.

\section{Buddhist carving}

On a horizontal slab one finds the carving of a large $(1.5 \times 3.5 \mathrm{~m})$ standing Bodhisattva in abhayamudrā holding a vase (?), and on another side of the boulder two seated Buddhas $^{92}$ (Fig. 33). 
Figure 33. Skuru : Buddhist carving. The Bodhisattva is $1.5 \times 3.5 \mathrm{~m}$

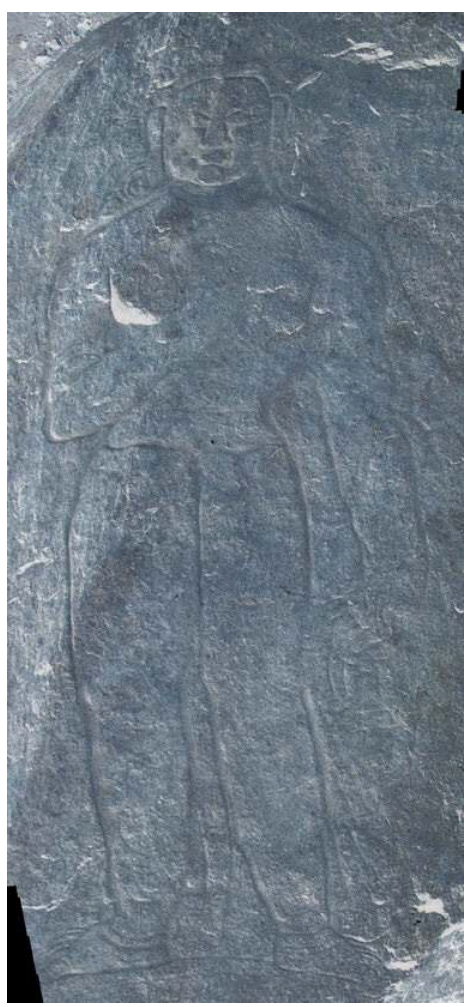

This image is the result of the merging of several pictures - there might as such be a bit of geometrical distortion

Devers 2010

\section{Fortified settlement}

The small plateau on the left bank of the side stream, above the road, is covered with five groups of chortens. Behind them, in the direction of the mountain, a small rock promontory bears the remains of a fort.

The walls are built with two main types of masonries, one using little to no mortar, the other using abundant mortar. We noticed four shards of ceramic with incised decoration. On the ridge that links the promontory to the mountain are two bases of square towers. They protect the thin ridge, which is the weakest angle of the fort in case of an attack. A fosse was additionally dug in front of the towers, in order to hinder any approach from this direction.

141 Descending stairs on the eastern side lead to further ruins. Bordered by the fort's promontory on one side and the cliff of the stream on the other, these ruins are likely those of an ancient fortified settlement. A rampart pierced with loopholes runs along the cliff. It turns in the direction of the promontory on its northern end. On this side, where the rampart faces the plateau, there is another wall built in front, along with a fosse, in order to further protect this weak side. Another weak angle is on the southern end of the promontory. Unfortunately, because of the current bulldozing of this area, nothing of the rampart is left. The habitations are too ruinous to be described, only depressions on the ground surrounded by piles of stones are to be seen. 


\section{Zangpo Chosling gonpa}

On top of the ridge, opposite Skuru, on the other side of the Shyok river, is a monastery known as Zangpo Chosling. A long path starting in Udmaru, constructed on the mountain flank, enables its access. Although at the present day there is no permanent monk, a room was recently built for the Rinpoche ( $r i n$ po che). Behind it are the ruins of several interconnected rooms that are probably the remnants of the original monastic complex. The villagers of Udmaru reused the bricks of this ancient building to build the new room for the Rinpoche. On one of the ruined walls is the painting of a small chorten, perhaps the last witness of more extensive wall paintings. According to local tradition, the monastery is from the same period as Ensa. As there is almost nothing left from the original building, it is not possible to assess the plausibility of this claim.

\section{Turtuk}

143 We ended our investigations at Turtuk, the last village before the Pakistani border. Turtuk is famous in Ladakh for its arts and crafts, in particular for its stone pots ( $r$ do ltok) and metal work. Its old mosque is also noticeable for its woodcarvings.

\section{Fortification}

Above the village, on a very steep face delineated by small cliffs in the middle of the mountainside, are the ruins of a vast fortification..$^{93}$ It is the steepest fortified site we have documented in Ladakh. The small cliffs that naturally protect the site prevented us from entering it. However, a few lower buildings are easier to approach. They are built in a schist-like masonry with little mortar.

\section{Yabgo Mod Khan Kacho's residence}

The residence of the rāja of Turtuk, Yabgo Mod Khan Kacho, stands out by its unique style (Fig. 34). In Ladakh, this type of architecture with closely laid timber lacings and cribbage columns, also known as 'cator and cribbage', is found only in the area of Turtuk..$^{94}$ The closest full expression of this architecture is in Baltistan, where it is commonly encountered as can be seen in the forts of Kharmang or Hunza. ${ }^{95}$ 
Figure 34. Turtuk : cator and cribbage architecture of the residence of Yabgo Mod Khan Kacho

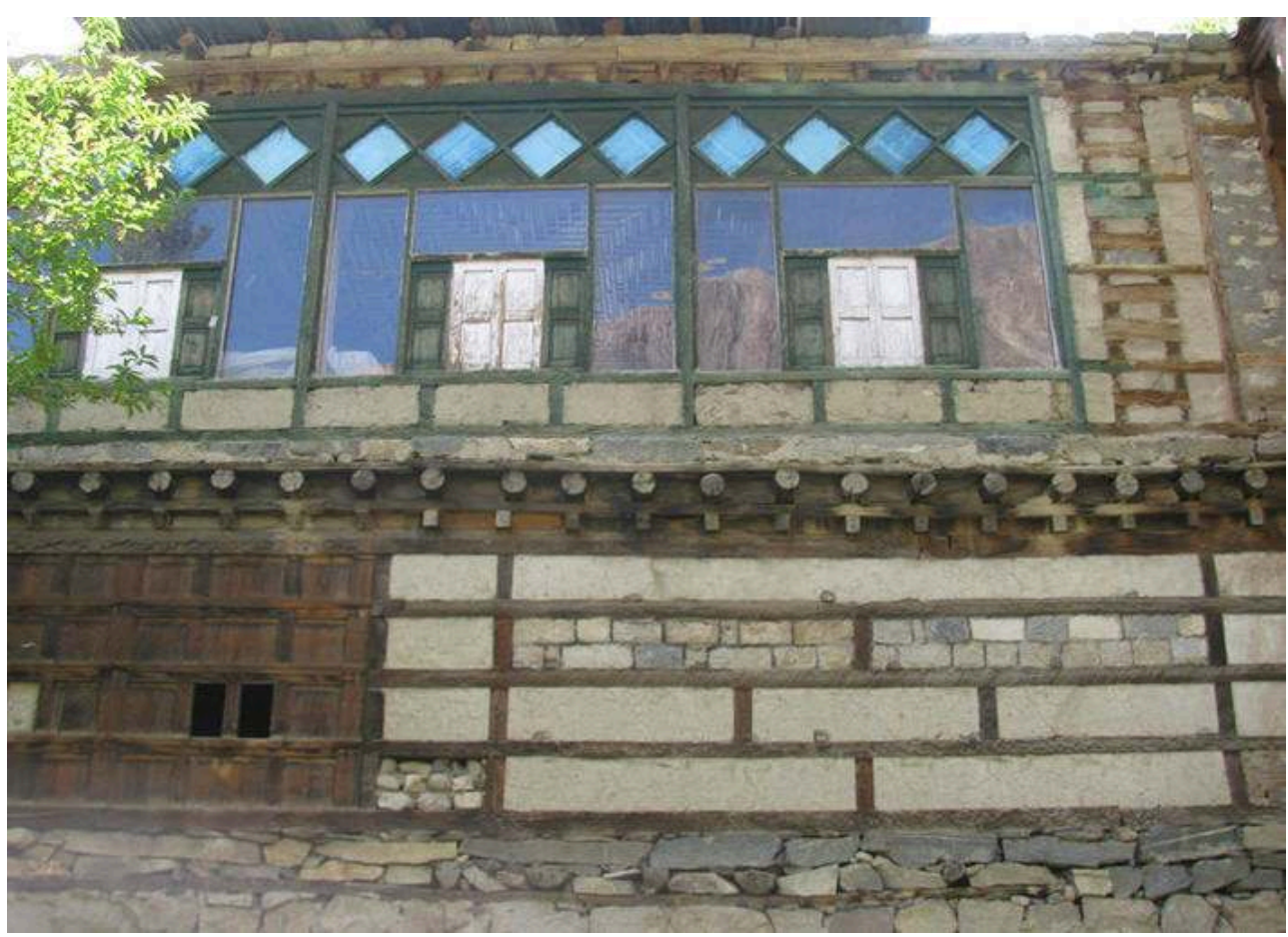

Devers 2010

The rāja had his lineage tree painted on one of the walls of his house (Fig. 35). According to it, the Yabgo dynasty originates from Western Turkestan, where it started with a prince called Tung. His first eleven successors were all from there, and their kingdom was confined to this area. In the 8th century, the twelfth in-line, Beg Menthal, extended his rule over "Balakh, Gandahar, Eastern Turkestan and Baltistan". The current rāja does not know from which religion the first twenty-six rulers were. Nonetheless, after Muqeem Khan, the twenty-sixth in line, the rājas converted to Islam. Whereas until Yabgo Sikiem (1550-1590), the thirty-second ruler, there was only one rāja for the entire kingdom, the latter divided it among his three sons. Following the invasion of part of Kashmir, these three sub-kingdoms were located in Pakistan. However, during the war of 1971 four villages of the sub-kingdom of Khapulu Chhorbat were taken over by the Indian army : Turtuk, Tharkshi, Chulungka and Thang. 


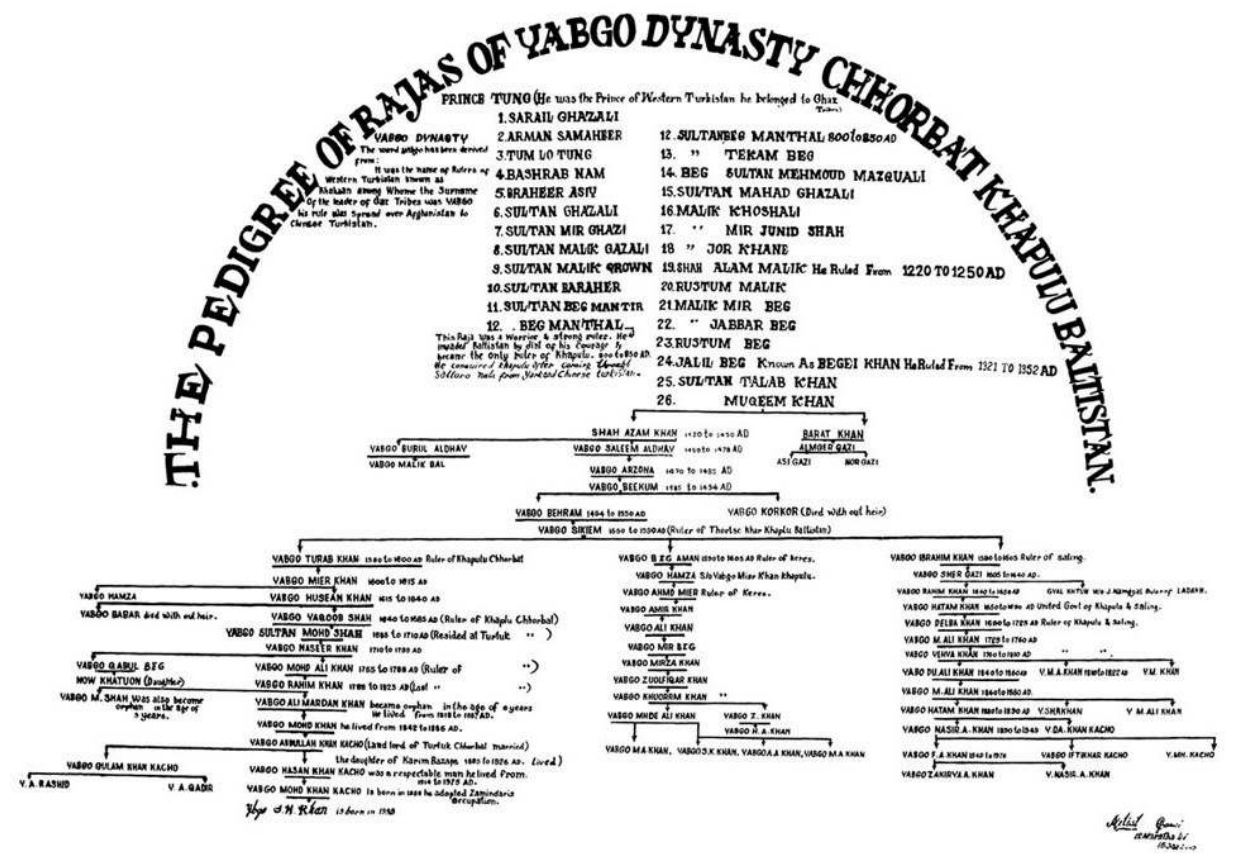

Devers 2010

147 We did not have access to the original documents that were used to produce this lineage. Our goal here is not to attempt a critical historical study of this material, but merely to raise awareness about its existence, in the hope of seeing it further researched in the future by competent historians. ${ }^{96}$

\section{Conclusion}

148 The surveys conducted by the authors show that the Nubra region houses a rich archaeological heritage, composed of rock art, graves, fortifications, inscriptions, early Buddhist remains and ruined settlements. The large number of sites (sixty-six) documented and their diversity enables us to propose a first cultural sequence for the region (see Annexes $1 \& 2$ ).

149 The surveys carried by the Archaeological Survey of India in the 1990s revealed the existence of lithic artefacts at Tirisa. ${ }^{97}$ Although further investigation is needed to specify their dating they point at a prehistoric occupation of Nubra. Regarding Protohistory the rock art and funerary sites surveyed provide evidence of cultural links with the steppic world. For the Bronze Age the thousand images documented in Murgi Tokpo display thematic and stylistic similarities with the rock art of Central Asia. These are reinforced by the existence at Panamik, on the opposite bank of the Siachen river, of graves typologically reminiscent of those of the Central Asian Bronze or Iron Ages. Similar features are found at Deskit. There, the presence of petroglyphs related to the 'animal style' provides further evidence for contacts with the Central Asian world during the Iron Age.

Unlike Central Ladakh, Nubra has no inscriptions from the first half of the 1st millennium AD. In fact, all the rock inscriptions found in the valley are in Tibetan. 
The earliest are undoubtedly those documented at Kushuwar and Chomolung, in proximity to the ancient Buddhist compound of Tirisa. The large ruined chorten with ladders on four sides, built on a rectangular platform and enclosed by walls, is reminiscent of monuments in Khotan and Kashmir dated to the last quarter of the 1st millennium AD. ${ }^{98}$

The early diffusion of Buddhism in Nubra is also well-evidenced by the stone sculptures. For instance, the stylistic features of the figures of Tirit's monumental relief (i.e. three-pointed crowns, rosettes over the ears and long garlands) are typical of Western Himalayan aesthetics. All these elements span a long period of time, from the 8th century with the Gilgit bronzes, to clay sculptures and paintings of the late 12thearly 13th century found in the temples of Alchi for example. ${ }^{99}$ Nevertheless, a date from the 11th-12th centuries could be proposed on the basis of comparison with bronzes such as that of Padmapāni owned by the Brooklyn Museum and that of Avalokiteśvara in the Norton Simon Museum. ${ }^{100}$ Undoubtedly Buddhism was well established in Nubra at the beginning of the second millennium AD.

The dates of non-iconographic and non-Buddhist remains, such as ruined villages and fortifications, are more difficult to ascertain. Whereas educated guesses are possible in some cases, we completely lack for the time being hard chronological data.

The various archaeological sites surveyed show strong influences from the Central Asian and Tibetan cultures. If Ladakh is often referred to as a "cultural crossroads", archaeology shows that Nubra played an important role over millennia as an interface between both worlds.

Based on the results of surveys presented in this paper an Indo-French cooperation project was put into place in 2012 with the Archaeological Survey of India by the authors. The MAFIL (Mission Archéologique Franco-Indienne au Ladakh, or IndoFrench Archaeological Mission in Ladakh), co-directed by S. B. Ota and L. Bruneau, is a four-year research project (2013-2016) that aims at specifying the chrono-cultural sequence of the Nubra region. The sites of Tirisa, Sumur-Maral, Deskit Ting gang and Murgi Tokpo were selected for further detailed on-ground studies, test excavations and radiocarbon dating. A range of specialists takes part in the project (ceramologist, funerary anthropologist, geomorphologist, geophysician and prehistorian), and it is hoped that this scientific endeavor, the first of its kind ever undertaken in Ladakh, will improve our understanding of the history of Nubra and of the interactions between the Central Asian and Tibetan worlds.

\section{BIBLIOGRAPHY}

Agrawal, R. C.

2012 Buddhist antiquities of Nubra Valley (Delhi, Sharada Publishing House), 299p.

Anonymous

1997 Exploration in Upper Indus Valley, district Leh, in A. Shankar (ed.), Indian Archaeology : a

Études mongoles et sibériennes, centrasiatiques et tibétaines, 46 | 2015 
review 1992-1993 (Delhi, Archaeological Survey of India), pp. 36-38.

2004 Exploration in Ladakh ; exploration in district Ladakh, in Director General Archaeological Survey of India (ed.), Indian Archaeology : a review 1998-1999 (Delhi, Archaeological Survey of India), pp. 49-59.

Bellezza, J. V.

2008 Zhang Zhung: foundations of civilization in Tibet. A historical and ethnoarchaeological study of the monuments, rock art, texts, and oral tradition of the ancient Tibetan upland (Vienna, Verlag der österreichischen Akademie der Wissenschaften), 841p.

Bruneau, L.

2013 L'art rupestre du Ladakh et ses liens avec l'Asie centrale protohistorique, in J. Bendezu Sarmiento (ed.), L'archéologie française en Asie centrale. Nouvelles recherches et enjeux socioculturelsCahiers d'Asie Centrale 21 / 22, (Tashkent, IFEAC), pp. 487-98.

in press Étude thématique et stylistique des pétroglyphes du Ladakh (Jammu et Cachemire, Inde) : une nouvelle contribution à l'art rupestre d'Asie centrale pour l'Âge du Bronze, Eurasia Antiqua, 18, pp. 1-19.

forthcoming Buddhist remains in the Nubra valley (Ladakh, Jammu \& Kashmir) : stone carvings and stūpas on the way to Central Asia, in B. R. Mani (ed.), Proceedings of the international seminar on "archaeology of Buddhism in Asia" (Delhi : Archaeological Survey of India).

Bruneau, L., Bellezza, J. V.

2013 The rock art of Upper Tibet and Ladakh : Inner Asian cultural adaptation, regional differentiation and the Western Tibetan Plateau style, Revue d'Études Tibétaines, 28, pp. 5-161.

Bruneau, L., Devers, Q., Vernier, M.

2011 Rock art researches in Murgi Tokpo, Nubra Valley, Ladakh, Purakala (The journal of the rock art society of India), 20, pp. 91-97.

Bruneau, L., Vernier, M.

2010 Animal style of the steppes in Ladakh : a presentation of newly discovered petroglyphs, in

L. M. Olivieri, L. Bruneau, M. Ferrandi (eds.), Pictures in transformation : rock art researches between Central Asia and the Subcontinent (Oxford, ArchaeoPress), pp. 27-36.

Bubnova, M. A.

2008 Arheologičeskaja karta Gorno-Badahšanskoj avtonomnoj oblasti : Zapadnyj Pamir : pamjatniki kamennogo veka - XX v. (Dushanbe, Universitet Central'noj Azii), 384p.

Cunningham, A.

1854 Ladák: physical, statistical, and historical ; with notices of the surrounding countries (London, W. H. Allen \& Co), 485p.

Desroches, J. P.

2003 Mongolie : le premier empire des steppes (Arles, Actes Sud), 227p.

Devers, $Q$.

in press An Archaeological Account of Nyarma and its Surroundings, Ladakh, in C. Jahoda,

C. Kalantari (eds.), Material on Western Tibet (Vienna, OAW).

Devers Q., Bruneau L., Vernier, M.

2014 An archaeological account of ten ancient painted chortens in Ladakh and Zanskar, in E. Lo Bue, J. Bray (eds.), Art and architecture in Ladakh cross-cultural transmissions in the Himalayas and Karakoram (Leiden, Brill), pp. 100-140. 
Devers, Q., Vernier, M.

2011 An archaeological account of the Markha Valley, Ladakh, Revue d'études tibétaines, 20, pp. 61-113.

De Filippi, F.

1924 Storia della Spedizione Scientifica Italiana nel Himàlaia, Caracorùm e Turchestàn Cinese (1913-1914)

(Bologna, Nicola Zanichelli), 541p.

De Terra, $\mathrm{H}$.

1931 Prehistoric caves north of the Himalaya, American anthropologist, 33, pp. 42-50.

Dorjay, P.

2010 Penetration of Buddhist ideology in Ladakh : a study through early rock sculptures, in L. M. Olivieri, L. Bruneau, M. Ferrandi (eds.), Pictures in transformation : rock art researches between Central Asia and the Subcontinent (Oxford, ArchaeoPress), pp. 43-58.

2014 Embedded in Stone-Early Buddhist Rock Art of Ladakh, in E. Lo Bue, J. Bray (eds.), Art and architecture in Ladakh cross-cultural transmissions in the Himalayas and Karakoram (Leiden, Brill), pp. 35-67.

Elias, N., Ross, D.

1898 A history of the Moghuls of Central Asia being the Tarikh-i-rashidi of Mirza Muhammad Haidar, Dughlat (London, S. Low, Marston and Company), 663p.

Emerson, R.

1984 Charismatic kingship : a study of state-formation and authority in Baltistan, Journal of Central Asia, 7/2, pp. 95-133.

Fisher, R.

1989 Buddhist architecture, in P. Pal, Art and architecture of ancient Kashmir (Bombay, Marg Publications), pp. 17-28.

Fonia, R. S.

1993 Ladakh corridor to Central Asia-An investigative report of pre-historic cultures, The Journal of Central Asian studies, 4/1, pp. 35-40.

Francke A. H.

1914 Antiquities of Indian Tibet, vol. I, Personal narrative (Calcutta, Superintendent Government Printing), 133p.

1921 Durch Zentralasien in die indische Gefangenschaft, (Herrnhut, Verlag der Missionsbuchhandlung), 172p.

1926 Antiquities of Indian Tibet, vol. II, The chronicles of Ladakh and minor chronicles, (Calcutta, Superintendent Government Printing), 310p.

1930 Notes on Khotan and Ladakh (V-Nubra-Khapulu), Indian antiquary, 59, pp. 43-45.

Francke, A. H., Jina, P. S.

2003 First collection of Tibetan historical inscriptions on rock and stone from Ladakh Himalaya (Delhi, Sri Satguru Publications), $161 \mathrm{p}$.

von Hinüber, 0 .

2004 Die Palola Șāhis : ihre Steininschriften, Inschriften auf Bronzen, Handschriftenkolophone und Schutzzauber. Materialen zur Geschichte von Gilgit und Chilas (Mainz, Philipp von Zabern), 215 p.

Hugues, R.

2000 Cator and cribbage construction of Northern Pakistan, earthquake- safe : lessons to be learned from traditional construction, International conference on the seismic performance of 
traditional buildings Istanbul, Turkey, Nov.16-18, 2000. Available at : http://www.icomos.org/iiwc/ seismic/Hughes-C.pdf [Seen on 2nd July 2012].

Jamspal, L.

1997 The five royal patrons and three Maitreya, in H. Osmaston, N. Tsering (eds.) Recent research on Ladakh. proceedings of the sixth international colloquia on Ladakh, Leh 1993, (Delhi, Motilal Banarsidass), pp. 139-156.

Jamwal S. D.

200 ? : A cop and his monumental work in Ladakh, en ligne http://www.himalayanaffairs.org/ interviewdetails.asp?id=43 [Seen on 1st March 2010].

2006 Rock carvings of Ladakh Himalayas, en ligne http://www.highasialadakh.com/index.php? option=com_content\&task=view\&id=48\&Itemid=9 [Seen on 1st March 2010].

Kapadia, $\mathrm{H}$.

2003 The god that did not fail - a journey across the Shyok and Nubra valleys, The Himalayan journal 59, en ligne https://www.himalayanclub.org/hj/59/13/the-god-that-did-not-fail/\#_ftn2 [Seen on 9th May 2014].

Kozicz, G.

2010 Stupa project. En ligne http://stupa.arch-research.at/cms/ [Seen on 2nd March 2014].

Linrothe, R.

2007 A winter in the field, Orientations, 38/4, pp. 40-53.

Luczanits, C.

2005 The early buddhist heritage of Ladakh reconsidered, in J. Bray (ed.), Ladakhi histories : local and regional perspectives (Leiden, Brill), pp. 65-96.

2004 Buddhist sculptures in clay : Early western Himalayan Art, late 10th to early 13th centuries (Chicago, Serindia Publications), 353p.

2002 The Wanla Bkra shis gsum brtsegs, in D. E. Klimburg-Salter, E. Allinger (eds.), Buddhist art and Tibetan patronage. Ninth to fourteenth centuries. PIATS 2000. Tibetan studies. Proceedings of the ninth seminar of the International Association for Tibetan Studies, Leiden 2000 (Leiden, Brill), pp. 115-125.

Maillard, M.

1983 Grottes et monuments d'Asie centrale. Essai sur l'architecture des monuments civils et religieux dans l'Asie centrale sédentaire depuis l'ère chrétienne jusqu'à la conquête musulmane (Paris, Adrien Maisonneuve), 282p.

Mani, B. R.

1998 Rock carvings and engravings in Ladakh : new discoveries, Pragdhara, 9, pp. 65-74.

2001 Rock art of Ladakh : glimpses of economic and cultural life, Purakala, 11-12, pp. 93-108.

Mumtaz, K., Bray, J., Devers, Q., Vernier, M.

2014 Chigtan Castle And Mosque : A preliminary historical and architectural analysis", in E. Lo Bue, J. Bray (eds.), Art and architecture in Ladakh cross-cultural transmissions in the Himalayas and Karakoram (Leiden, Brill), pp. 254-273.

NIRLAC (Namgyal Institute for Research on Ladakhi Art and Culture)

2008 Legacy of a mountain people. Inventory of cultural resources of Ladakh, volume 4, Leh-Nubra (New Delhi : NIRLAC), 424p.

Orofino, $G$.

1990 A note on some Tibetan petroglyphs of the Ladakh area, East and West, 40, pp. 173-200.

Poell, H.

2014 The wood carvings of Lachuse. A hidden jewel of early mediaeval Ladakhi art, in E. Lo Bue, 
J. Bray (eds.), Art and architecture in Ladakh cross-cultural transmissions in the Himalayas and Karakoram (Leiden, Brill), pp. 191-226.

Quarter Master General's Dept. Intelligence Branch India

1890 Gazetteer of Kashmir and Ladák ; together with routes in the territories of the Maharája of Jamú and Kashmír. compiled (for political and military reference) under the direction of the Quarter Master General in India in the Intelligence Branch. (Calcutta, Superintendent of Government Printing India), 1102p.

Ranov, V. A.

1984 L'exploration archéologique du Pamir, Bulletin de l'École française d'Extrême-Orient, 73, pp. 67-97.

Rizvi, J.

1999 Trans-Himalayan caravans. merchant princes and peasant traders in Ladakh (New Delhi, Oxford University Press), 359p.

Stein, A.

1912 Ruins of desert Cathay- personal narrative of explorations in Central Asia and Westernmost China, II (London, Macmillan \& Co.), 517p.

1921 Serindia - Detailed report of explorations in Central Asia and westernmost China, III (Oxford, Clarendon Press), pp. 1090-1580.

Tshangpa, T. L.

2007 A short note on some petroglyphs of the Nubra valley, in J. Bray, N. T. Shakspo (eds.), Recent research on Ladakh 2007 (Leh, J. \& K. Academy for Art, Culture and Languages), pp. 53-60. 2014 Ancient petroglyphs of Ladakh : new discoveries and documentation, in E. Lo Bue, J. Bray (eds.), Art and architecture in Ladakh cross-cultural transmissions in the Himalayas and Karakoram (Leiden, Brill), pp. 15-35.

Urgyan, R.

2010 Nub-ra'i gNas-bShad (Leh, Himalayan Cultural Heritage Foundation).

Vohra, R.

1985a Historical documents from the Nubra Valley- Part 1 : facsimile edition of stone-inscriptions and of the history of the bDe-skyid-Monastery, in D. Schuh, M. Weiers, Archiv für Zentralasiatische Geschichtforschung, 7, (Sankt Augustin, VGH Wissenschaftsverlag) pp. 3-15.

1985 b Ethno historical notes on Nubra in Ladakh, Ladakh, in C. Dendaletche (ed.), Himalaya occidental ethnologie, écologie : recent research $n^{\circ} 2$ (Pau, Centre pyrénéen de biologie et anthropologie des montagnes), pp. 247-256.

1990 Mythic lore and historical documents from Nubra valley in Ladakh, Acta Orientalia Academiae Scientiarum Hung, 44, 1-2, pp. 225-239.

Wangchok, S.

2009 Sacred landscapes in the Nubra valley, in J. Bray, E. De Rossi Filibeck, Mountains, monasteries and mosques. Recent research on Ladakh and the Western Himalaya, proceedings of the 13th colloquium of the International Association for Ladakh Studies- Supplement No. 2 to Rivista degli Studi Orientali 80, New Serie (Pisa \& Rome, Fabrizio Serra Editore).

Wilson, $\mathrm{H} . \mathrm{H}$.

1841 Travels in the Himalayan provinces of Hindustan and the Panjab ; in Ladakh and Kashmir ; in Peshawar, Kabul, Kunduz, and Bokhara (London, J. Murray), 459p.

Wu Xinhua, Wagner, M., Görsdorf, J., Tarasov, P., Aisha, A., Mei Jianjun 2006 Das Gräberfeld Liushui des 9. bis 7. Jahrhunderts v. Chr. im Kunlun-Gebirge, NW-China. Vorbericht über die Ergebnisse der Ausgrabungen 2002 bis 2005, Eurasia Antiqua, 12, pp. 173-191. 
Zodpa, K. L., Shapsko, N. T.

1982 History of the Nubra Valley, Mundgod.

\section{APPENDIXES}

\section{Annex $1:$ list of surveyed sites}

\begin{tabular}{|c|c|c|c|}
\hline Location & Type of remains & Chronology & $\mathrm{N}^{\circ}$ on map \\
\hline Chamchen & Ruined enclosure & $?$ & 11 \\
\hline Chamchen & Tower & $?$ & 10 \\
\hline Charasa & Fortified settlement & History & 41 \\
\hline Charasa & Petroglyphs & Protohistory \& history & 42 \\
\hline Chomolung & Inscriptions & Early history & 13 \\
\hline Chomolung & Petroglyphs & Protohistory \& history & 12 \\
\hline Deskit & Buddhist carving & Early history & 52 \\
\hline Deskit & Tower & History & 51 \\
\hline Deskit Phu & Temple & Early history & 53 \\
\hline Deskit Phu & Petroglyphs & Protohistory \& history & 54 \\
\hline Deskit Tingang & Buddhist ruins & Early history & 55 \\
\hline Deskit Tingang & Funerary site & Protohistory & 56 \\
\hline Deskit Tingang & Petroglyphs & Protohistory \& history & 57 \\
\hline Digar & Buddhist carving & Early history & $(43)$ \\
\hline Ensa & Ancient chortens & Early history & 29 \\
\hline Ensa & Buddhist carving & Early history & 30 \\
\hline Ensa & Petroglyphs & Protohistory \& history & 28 \\
\hline Guri & Petroglyphs & Early history & 38 \\
\hline Guri & Ruined buildings & Early history? & 39 \\
\hline Guri & Ruined settlement & History & 40 \\
\hline Hundar & Buddhist carving & Early history & 59 \\
\hline
\end{tabular}




\begin{tabular}{|c|c|c|c|}
\hline Hundar & Fortified settlement & History & 58 \\
\hline Hundar Brog & Buddhist carving & Early history & 62 \\
\hline Hundar Brog & Buddhist ruins & Early history & 60 \\
\hline Hundar Brog & Fortified settlement & Early history? & 61 \\
\hline Kharpoche & Buddhist carving & Early history & $(45)$ \\
\hline Kharpoche & Fortified settlement & Early history? & $(44)$ \\
\hline Kharpoche & Petroglyphs & Early history & (46) \\
\hline Khyagar & Buddhist carving & Early history & 4 \\
\hline Khyagar & Palace and ruined settlement & Late history & 5 \\
\hline Khyagar & Petroglyphs & $?$ & 6 \\
\hline Kushuwar Thang & Fortification & $?$ & 17 \\
\hline Kushuwar Thang & Funerary site? & Protohistory & 18 \\
\hline Kushuwar Thang & Inscriptions & Early history & 15 \\
\hline Kushuwar Thang & Petroglyphs & Protohistory \& history & 14 \\
\hline Kushuwar Thang & Ruins & History & 16 \\
\hline Murgi Tokpo & Petroglyphs & Protohistory \& history & 31 \\
\hline Murgi Tokpo & Ruined settlement & $?$ & 32 \\
\hline Murgi village & Ancient chortens & Early history & 36 \\
\hline Murgi village & Fort A & $?$ & 33 \\
\hline Murgi village & Fort B & $?$ & 34 \\
\hline Murgi village & Fort C & $?$ & 35 \\
\hline Murgi village & Petroglyphs & Protohistory \& history & 37 \\
\hline Panamik & Funerary site & Protohistory & 27 \\
\hline Panamik & Petroglyphs & Early history & 26 \\
\hline Panamik & Ruined settlement & History & 25 \\
\hline Rongdo & Petroglyphs & Protohistory & $(47)$ \\
\hline Skuru & Buddhist carving & Early history & 63 \\
\hline
\end{tabular}




\begin{tabular}{|c|c|c|c|}
\hline Skuru & Fortified settlement & History & 64 \\
\hline Sumur Maral & Fort & History & 7 \\
\hline Sumur Maral & Fortress & History & 8 \\
\hline Sumur Maral & Top tower complex & History & 9 \\
\hline Sumur & Buddhist carving & Early history & 2 \\
\hline Sumur & Buddhist ruins & Early history? & 3 \\
\hline Sumur & Ruined settlement & $?$ & 1 \\
\hline Tirisa Lake & Fort & History & 21 \\
\hline Tirisa Lake & Fortified settlement & Early history? & 20 \\
\hline Tirisa Lake & Inscriptions & Early history & 23 \\
\hline Tirisa Lake & Large ruined building & Late history? & 19 \\
\hline Tirisa Lake & Petroglyphs & Protohistory \& history & 22 \\
\hline Tirisa Lake & Buddhist ruins & Early history & 24 \\
\hline Tirit & Buddhist carving & Early history & 49 \\
\hline Tirit & Petroglyphs & Protohistory \& history & 50 \\
\hline Turtuk & Fortification & History & (66) \\
\hline Yulkam Tokpo & Petroglyphs & Protohistory & $(48)$ \\
\hline Zangpo Chosling Gonpa & Buddhist ruins & Early history & 65 \\
\hline
\end{tabular}

\section{Annex 2 : surveyed sites by period}

\begin{tabular}{|l|l|}
\hline Protohistory & Early history \\
c. 2nd millennium BC - & c. 8th c. AD - c. 13th c. AD \\
c. 8th century AD & \\
\hline
\end{tabular}




\begin{tabular}{l|l} 
Charasa : petroglyphs & Digar : Buddhist carving \\
Chomolung : petroglyphs & Ensa : ancient chortens \\
Deskit Phu : petroglyphs & Ensa : Buddhist carving \\
Deskit Tingang : funerary site & Ensa : petroglyphs \\
Deskit Tingang : petroglyphs & Guri : petroglyphs \\
Ensa : petroglyphs & Hundar Brog: Buddhist carvings \\
Kushuwar Thang: funerary site $?$ & Hundar : Buddhist carving \\
Kushuwar Thang : petroglyphs & Kharpoche : Buddhist carving \\
Murgi Tokpo : petroglyphs & Kharpoche : petroglyphs \\
Murgi village : petroglyphs & Khyagar : Buddhist carving \\
Panamik : funerary site & Kushuwar Thang : inscriptions \\
Rongdo : petroglyphs & Kushuwar Thang : petroglyphs \\
Tirisa Lake : petroglyphs & Murgi Tokpo : petroglyphs \\
Tirit : petroglyphs & Murgi village : ancient chortens \\
Yulkam Tokpo : petroglyphs & Murgi village : petroglyphs \\
Panamik : petroglyphs \\
Skuru : Buddhist carving \\
Sumur : Buddhist carving \\
Tirisa Lake : inscriptions \\
Tirisa Lake : Buddhist ruins \\
Tirisa Lake : petroglyphs \\
Tirit : Buddhist carving \\
Tirit petroglyphs
\end{tabular}

Charasa : petroglyphs

Chomolung : inscriptions

Chomolung : petroglyphs

Deskit : Buddhist carving

Deskit Phu : temple

Deskit Phu : petroglyphs

Deskit Tingang : Buddhist ruins

Deskit Tingang : petroglyphs

Digar : Buddhist carving

Ensa : ancient chortens

Ensa : Buddhist carving

Ensa : petroglyphs

Guri : petroglyphs

undar Brog : Buddhist carvings .

ist carving

Kharpoche : petroglyphs

Khyagar : Buddhist carving

Kushuwar Thang : inscriptions

ushuwar Thang : petroglyphs

Murgi Tokpo : petroglyphs

ge : ancient chortens

\section{NOTES}

1. The river is most commonly mapped as 'Nubra' but it is locally known as Siachen. 
2. About the history of the trans-Karakoram trade route : Rizvi 1999, pp. 183-206.

3. Wilson 1841, p. 404.

4. Stein 1912, pp. 486-87; 1921, pp. 1326-27.

5. The manuscript of Francke entitled First collection of Tibetan inscriptions dating from 1905 was edited and published by Jina in 2003 only : Francke / Jina 2003. For votive plates and inscriptions see : Nos. 39, 71, 73 and 83 from Deskit ; Nos. 40, 41, 57 and 85 from Hundar ; No. 56 from Rongdo. 6. In this paper we decided, for several reasons, to provide Wylie spellings only for common Tibetan nouns and historical figures. First of all, the Wylie spellings of most places mentioned in this paper are unknown. When they are, more and often than not, there is no agreement on the spelling. The very name of Nubra well illustrates it as the region is either spelled nub ra or ldum ra. Furthermore, the toponyms of the region are not all of Tibetan origin.

7. Francke 1921, pp. 122-31;1930, p. 45.

8. De Terra 1931.

9. Vohra 1985b, pp. 248-250; 1990.

10. Vohra 1985a, pp. 11-14.

11. Zodpa / Shakspo 1982.

12. Urgyan 2010. On the sacred landscapes (mountains, lakes, caves, trees and prints) of Nubra see also Wangchok 2009.

13. Elias / Ross 1898, p. 418.

14. Fonia 1993 ; Anonymous 1997, pp. 36-37.

15. Anonymous 2004 , p. 59.

16. Jamwal 200 ?, 2006 ; Tshangpa 2007, 2014.

17. Dorjay 2010, pp. 53-56 (Fig. 22-21, Tirit) ; p. 56 (Fig. 22, Hundar).

18. Kozciz 2010.

19. NIRLAC 2008. The volume dedicated to Nubra is the fourth one of a series of 6 covering the whole of Ladakh. The publication of volumes 5 and 6 is still pending.

20. Agrawal 2012.

21. Bellezza 2008, p. 20-25, 39. As defined by Bellezza, in Upper Tibet the "archaic cultural horizon" designates sites that present a set of characteristics and morphologic attributes distinguishing them from Buddhist monuments and other constructions influenced by Central Tibetan architecture. According to him, such sites derive from a tradition that probably originates from the times of the so-called Zhang Zhung entity mentioned in the texts. However, all sites do not necessarily date from the times of this entity (that is to say prior to the 7th century $\mathrm{AD}$ ) : some of them were built after the conquest of Upper Tibet by Central Tibet, even after the second spread of Buddhism, and still incorporated these characteristics. Without necessarily pertaining to any Zhang Zhung influence, this notion of "archaic cultural horizon" can be applied to Nubra to designate sites that present characteristics deriving from a tradition anterior to the introduction of Buddhism and of Tibetan influence in the region.

22. As a convention, measurements in this article for Buddhist carvings are hereafter given in the format width $x$ height. Brick dimensions are given in the format length $x$ width $x$ thickness.

23. Dorjay 2014, p. 63 (Fig. 2.24).

24. Mentioned under Sumur in: Anonymous 1997, p. 37 (Pl. XIIIA); Agrawal 2012, pp. 145-47. Mentioned under Sumstaling in : Mani 1998, p. 70 ; 2001, p. 103.

25. A hundred meters behind the monastery compound, just outside the limit of the irrigated land, are the remains of ancient walls made of large boulders delimiting flat terraces. Contiguous to some very large rocks, and partly excavated under them, these might be the remains of tombs. The area has obviously been reused as a cremation ground for a significant period of time and these activities, involving some minor masonry work, have much altered the ancient remains.

26. The monastery as it stands today and as asserted by the tradition was founded in 1870 by the famous monk, scholar and reformer Lama Tsultrim Nyima (tshul khrims nyi ma) (1796-1872), who 
also founded Rizong monastery (Central Ladakh). On the monastery of Samstanling: Agrawal 2012, pp. 137-145 ; NIRLAC 2008, p. 339.

27. NIRLAC 2008, p. 219.

28. As of 2014 , over 252 fortifications were inventoried by the authors in Ladakh. The only mention of the fortress in Sumur is : Kapadia 2003, photograph 25.

29. See for example Jamchun fortress : Ranov 1984, p. 82 ; Bubnova 2008, p. 291-293.

30. Ranov 1984, p. 83.

31. Kapadia (2003) reports the name of the fortress as Tsogmak (tsog mak, or Mongolian army). He also reports a legend according to which the fort is believed to have been built at the time of a Mongol invasion in Ladakh, but it is not clear whether it refers to the time of Gengis Khan (13th century) or to the Mongol armies of the fifth Dalai Lama during the Tibet-Ladakh-Mughal war (end of the 17th century).

32. According to the villagers the lhatho now inside the fortress was originally set in the tower -it is only relatively recently that the villagers moved it to its current location.

33. De Filippi 1924, p. 312.

34. Quarter Master General's Dept. Intelligence Branch India 1890, p. 100.

35. Kapadia 2003, photograph 24.

36. Ibid.

37. These inscriptions, as well as those of Kushuwar Thang, were submitted for transliteration and translation to Prof. Dieter Schuh who kindly provided a detailed reading on the 12th of May 2014. We thank him very much for his precious help.

38. Dachompa Nyima Gungpa was a wandering Nyingmapa monk and tantric practitioner. The dates of his lifetime are unknown.

39. NIRLAC 2008, p. 373.

40. On the pilgrimages see NIRLAC 2008, p. 374.

41. On the lithic artefacts : Fonia 1993, pp. 36-37 (Fig. 1). The following remains are listed at Tirisa by the ASI : a pre-historic site, rock engravings of ibex and hunting scene, watchtower and toll post of Dard rulers : Anonymous 1997, p. 37.

42. One of the few other fortifications using mostly bricks is Phyang (Central Ladakh). In the Nubra, the earliest stage of construction of Charasa, as described below in the article, seems also characterised by an important use of bricks.

43. Mani 1998, p. $71 ; 2001$, p. 103.

44. These inscriptions were transliterated and translated by Prof. D. Schuh who provided a reading on the 11th of May 2014.

45. This chorten is mentioned by Agrawal 2012, pp. 110-111.

46. Of interest, among the stones on the enclosure of one the tombs are two fragments of an engraved hunting scene. The upper body of an archer is identifiable as well as the feet of another anthropomorphic figure and the bodies of three animals. The path of the arrow shot by the archer is depicted and could suggest a Bronze Age date. The boulder or the rock from which these two fragments originated could not be found in the area.

47. See types II.2a, II.2b and II.2c of Bellezza's typology of funerary sites (Bellezza 2008, pp. 110-128).

48. For examples in Mongolia, see : Desroches 2003, pp. 104-107. For examples in the Tarim basin, see : Wu et al. 2006.

49. The petroglyphs were previously reported under the name Yansa: Mani 1998, p. $71 ; 2001$, p. 103.

50. NIRLAC 2008, p. 261 ; Kozicz 2010.

51. For a list of chortens in Ladakh with moulded lotus petals see footnote 16 in Devers et al. 2014 .

52. This chorten is reported by Kozicz 2010 under the name Ensa, Stupa 2. For Malakartse Khar : Linrothe 2007, Fig. 2. 
53. In front of this construction are a large number of holes in the ground, about $10 \mathrm{~cm}$ in diameter, surrounded by small cairns. Believers plunge their hands in one of the hole and the content of the dirt they extract predicts the gender of their forthcoming child and its fate.

54. Sherab Zangpo (1400-1425 or 1438) was the twelfth abbot of Ralung monastery (Western Tibet), which is the traditional seat of the Drukpa order. In Nubra he is said to have founded the monasteries of Ensa and Deskit. On the monastery and its foundation: NIRLAC 2008, p. 258 ; Agrawal 2012, pp. 225-229.

55. Luczanits dated the foundation of the Sumtsek as being from the early 13th century: Luczanits 2007, p. 73. Other examples are found in the Lotsawa Lhakhang in Alchi, as well as in the temples of Sumda Chung, Mangyu, Wanla, and Kanji Lhachuse. Sumda Chung and Mangyu are part of what Luczanits calls the "Alchi group of monuments", which he dates to be from around 1200 : Luczanits 2005, p. 86. Luczanits dates the foundation of the temple of Wanla as being between the end of the $13^{\text {th }}$ and the early 14th century, "most likely the first half of the fourteenth century": Luczanits 2002, p.124. Poell dates the wood carvings of Lhachuse as preceding the Alchi Sumstek, so as being from before the 13th century : Poell 2014, p. 221.

56. NIRLAC 2008, p. 258.

57. The petroglyphs of Murgi were first reported by the ASI (Anonymous 1997, p. 37 ; 2004, p. 59 ; Mani 1998, p. 71, 2001, p. 103) under the name Murgi nala, nala being the hindi equivalent of the Tibetan tokpo. A rock shelter is also mentioned at Murgi : Anonymous 1997, p. 37.

58. Mascoids from Murgi Tokpo in comparison with those of Upper Tibet and Inner Asia are discussed at length in Bruneau / Bellezza 2013. See also Bruneau in press.

59. On the stylistic features see Bruneau et al. 2011, Bruneau 2013, in press.

60. Other examples are the rock art sites at Tahan Tungri in Zanskar and those of Umla Thang and Sabu Lungmoche in central Ladakh. It should be noted that, in Ladakh, bayuls are not strictly linked to Padmasambhava in the same way they usually are in other Himalayan regions. The origin and identity of the bayuls we documented in Ladakh in relation to archaeological ruins are rather unclear and local traditions are not unanimous.

61. This was unnecessary for Fort A as it stands on an outcrop. There was already a natural vertical distance between the buildings and the outer ground down below

62. NIRLAC 2008, p. 260.

63. Ibid.

64. The murals are in a very bad state of conservation; only few parts remain on the walls. In these, some stylistic and iconographic elements (lotus petals of the main deities and armbands of their assistant bodhisattvas) remind those on the murals of the Tashi Sumtsek in Wanla or of the Lhakhang Soma in Alchi, thus suggesting a dating from c. the first half of the 14th century : private communication from Nils Martin, 3rd of March 2014. N. Martin is a Phd candidate at the École Pratique des Hautes Études (Paris) and conducts researches on the 14th and 15th centuries Buddhist wall paintings of Ladakh.

65. NIRLAC 2008, p. 261.

66. According to the villagers, a long time ago the ancient inhabitants died altogether of disease or war. Then, the dead rose again, becoming rolangs (ro lang) or rising-dead. Some other people came and killed these rolangs once for all and buried them in these two constructions, which they then destroyed.

67. On the fort of Charasa and its temples: NIRLAC 2008, p. 53. On the mythic lore of Charasa village : Vohra 1985b, p. 248 ; 1990, pp. 226-229.

68. See Mumtaz et al. 2014 for other capitals carved with interlaced figures in Ladakh (Chigtan).

69. Some of these capitals inside the palaces have been repeatedly marked with butter dots (yar) over time or are adorned with sheaves of barley tied around their shaft as an offering. Both these practices testifying of the important role, beyond the architectural one, of the column $(\mathrm{ka})$ and the beliefs associated with it. 
70. The only mention of this carving is found in : NIRLAC 2008, p. 89. Only one photograph of the temple was published but none of the carving itself.

71. NIRLAC 2008, p. 88 ; Dorjay 2010, p. 53 (Figs. 17-19), 2014, p. 61 (Fig. 2.22).

72. A votive inscription from Rongdo mentioning king Sengge Namgyal (17th century) was reported by Francke : Francke / Jina 2003, No. 56.

73. NIRLAC 2008, p. 381.

74. Anonymous 1997, p. 37 (Pl. XIIIB) ; NIRLAC 2008; p. 366 ; Dorjay 2010, p. 56 (Figs. 20 \& 21), 2014, p. 63 (Fig. 2.23).

75. These petroglyphs are reported by Mani : 1998, p. $71 ; 2001$, p. 103. The petroglyphs reported under the name Tirat Tirit are most probably the same: Anonymous 1997, p. 37.

76. On the gonpa of Deskit and its temples: NIRLAC 2008, p. 60 ; Agrawal 2012, pp. 15-23. On the palatial remains : ibid., pp. 23-24. On the history of Deskit: Vohra 1990, pp. 233-235. A votive tablet was found in Deskit by Francke that bore the name of Drakpabum (Grags-pa-'bum, second half of the 15th century), who is said to have been in Nubra when emissaries of Tsongkhapa came to see him: Francke 1926, p. 99, 102 ; see also Francke / Jina 2003 : inscription no. 39 (hymn to Tsongkhapa). On the emissaries of Tsongkhapa and the dates of reign of Drakpabum see: Jampspal 1997, pp. 141-144. For other votive plates from Deskit bearing hymns to three rulers of the Namgyal dynasty (18th century) : Francke / Jina 2003, Nos. 71, 73 \& 83.

77. NIRLAC 2008, p. 62.

78. Anonymous 1997 , p. 36 : it is not clear whether the term 'rock engravings' refers to the Buddhist slab below the monastery or to the petroglyphs described below.

79. The site is inventoried by NIRLAC under the name Chomo Tsamphuk : NIRLAC 2008, p. 61.

80. We are indebted to Nils Martin for sharing this dating with us : private communication to Quentin Devers, 26th of September 2014.

81. As for their relative chronology, we know that temple 3 was built after temple 2. However, there is no direct stratigraphic relationship between temple 1 and temple 2 . As such, the chronological order of the three temples could be either 1-2-3, 2-1-3, or 2-3-1.

82. Mani 1998, p. 70 ; 2001, p. 103 ; Jamwal 200 ?; Thsangpa 2007, p. 57.

83. Francke 1930, p. 44 ; Vohra 1985a, pp. $11-14$; Francke / Jina 2003 : inscriptions Nos. 57 \& 85 refer to two rulers of the Namgyal dynasty (17th and 19th centuries) whereas inscriptions Nos. 40 \& 41 mention local rulers. As stated by Vohra (1990, p. 233) it would be hazardous to identify them as there are, for the time being, no other source available. Nonetheless Vohra tentatively dates the inscriptions from the 16th century

84. The fort is briefly mentioned in : Anonymous 1997, p. 36 ; NIRLAC 2008, p. 107 ; Agrawal 2012, p. 74. According to inscriptions on some of the votive tablets, Vohra proposes the name Dechen Tsemo (bde chen rtse mo) for this site: Vohra 1985a, pp. 12-13. Elias \& Ross (1895, p. 41, footnote) proposed that the town "Mutadar" referred to by Mirza Haidar (1499-1551) in his memoirs, which he states to have been the chief fort of Nubra, is to be identified with Hundar. However, they base this identification solely on speculative phonetic grounds: "This name may also read Maut-dār, but is probably intended for Hundar, near the junction of the Nubra and Shayok rivers. The chief village, and seat of the district officials in the Nubra is, nowadays, Tagdr - a name which bears a certain resemblance to a part of the word Mutadār." (ibid.) We would like to notice here that in his siege of the fort, Mirza prepared catapults (Elias / Ross 1895, p. 41). The use of such siege engines might be an indication of the place where the battle took place. Indeed, the fortified settlement in Hundar is bordered by high cliffs on the north, i.e. on the main valley side, making the use of catapults likely pointless from that angle. Catapults could probably have been successfully set for an attack from the south, i.e. from the side valley; however the entrance of this side valley is very narrow and one has to pass right below the settlement's defences : it is not certain that an enemy could have safely entered the side valley to set catapults there. The other major fortifications of the region are : Charasa, Deskit and Sumur-Maral. The latter can be safely 
crossed-out as its location is incompatible with the use of catapults. The two remaining ones, Charasa and Deskit, are both plausible candidates for such siege. The fortified settlement of Charasa is set on a low hill with flat open ground on all sides, leaving plenty of options to set catapults up at will. As we saw earlier, its shuttered-mud walls bear the marks of important damage, which in some parts was inflicted only in the upper part of the elevations -this type of destruction suits the action of catapults. At Deskit, though the fort is highly situated making the use of catapults from the valley floor unlikely, it faces a plateau on the other side of the torrent that is just as high. The distance between the fort and the plateau is reduced, less than a hundred meters. As such, it is conceivable that catapults could have been set there and successfully used against the fort. Furthermore, only few bits of shuttered-mud walls are still standing suggesting that heavy destruction took place. Therefore either Charasa or Deskit fit the description of being the chief fort of Nubra and to have faced catapults. We can further notice that as Elias and Ross (ibid.) state, at one time Charasa was known to be the chief place of the valley.

85. Near the entrance, outside the fort, is a boulder engraved with various motifs of light patina (mainly anthropomorphic figures, animals, swastikas and modern inscriptions in Latin alphabet). These petroglyphs are also reported by Mani : 1998, p. $70 ; 2001$, p. 103.

86. About the temples: NIRLAC 2008, p. 116 ; Agrawal 2012, pp. 72-74.

87. See above footnote 83 ; NIRLAC 2008, p. 108.

88. Vohra 1985b, p. 248 ; Vohra 1990, p. 231 ; Anonymous 1997, p. 36 (Pl. XII) ; Dorjay 2010, p. 56 (Fig. 24), 2014, p. 65.

89. Vohra 1985b, p. 248 : Vohra refers to another image opposite the boulder described above and reportedly destroyed at the time of construction of the power house. This story has been confirmed to us by villagers in 2011.

90. Fonia 1993, pp. 37-38; Anonymous 1997, p. 37.

91. We are indebted to Abram Pointet (associate professor, EPFL, Lausanne) for bringing this large fortified site to our attention : personal communication to Martin Vernier in March 2013.

92. Vohra 1985b, p. 248, 1990, p. 232. According to Vohra, earlier the rock was seen standing but during a Mongol invasion, the leader of the army, having failed to capture the fort had, in his anger, the rock knocked down so that the image now lies on its back. For the relief, see also NIRLAC 2008, p. 330.

93. For a short description of the fort of Turtuk: Vohra 1990, p. 229. Vohra reports the local name of the fort as being Brogpai Khar (pp. 229-231).

94. One exception lies in Sumur. Indeed, a chorten built on the roof of a private temple belonging to the Onpo family, Onpa Gonpa, stands on four short cribbage columns. It is the western-most expression of this type of architecture we have noticed in the Nubra.

95. For a quick report about this type of architecture in Northern Pakistan see Hugues 2000. For pictures of the forts in Kharmang and Hunza see respectively De Filippi 1924, p. 36 and Hugues 2000, p. 3, 8 .

96. Cunningham compiled dynastic lists pertaining to the dynasties of Khapulu and Keris in Baltistan, in which several names depicted in the lineage tree in Turtuk can be recognised. Cunningham 1854, pp. 29-31. For comments on the lineage see also Francke 1930, p. 44. Emerson published a dynastic list in which the second name is 'Baig Manthal' (we are indebted to John Mock for pointing this reference to us). Emerson 1984.

97. Fonia 1993, pp. 37-38 (Fig. 1) ; Anonymous 1997, p. 37.

98. For instance, the stūpas of Rawak in Khotan and that of Ushkur in Kashmir present the same plan : see respectively Maillard 1983, pp. 166-169 and Fisher 1989, pp. 22-24. Agrawal proposes a date of the 8th century for the chorten of Tirisa but he does not provide any arguments for his statement : Agrawal 2012, p. 111.

99. Hinüber 2004, pp. 149-176 ; Luczanits 2004 ; Bruneau forthcoming. 
100. Images of these bronzes can be found online on the websites of the museums. Accession number of the bronze of Padmapāni in the Brooklyn Museum : 78.256.4 (1050-1150, H 28cm). Accession number of the bronze of Avalokiteśvara in the Norton Museum : F.1976.05.14.S (Tibet, 1100-1199, brass inlaid with gold, silver, turquoise and pigment, 40x16.5x8.3cm).

\section{ABSTRACTS}

The Nubra region discussed in this paper is the northernmost of Ladakh (Jammu and Kashmir, India). Although some archaeological surveys have been conducted in the region since the 1990s no comprehensive account has yet been attempted : it is the aim of this paper to do so. The work presented here is the result of extensive surveys conducted by the authors between 2006 and 2014 (six campaigns), which revealed sixty-six valuable sites, many previously unreported. They bring to light, among others, long searched Protohistorical funerary sites, the largest and richest Bronze Age rock art site of Ladakh, several ancient Buddhist carvings and ruined monuments as well as new evidence of architectural contacts with Central Asia.

La Nubra est la région la plus septentrionale du Ladakh (état de Jammu et Cachemire, Inde). Bien que des prospections archéologiques y aient été menées de manière épisodique depuis les années 1990 aucune étude d'ensemble n'a été proposée. Cet article vise à combler ce manque et présente les résultats de prospections approfondies conduites par les auteurs. Six campagnes, menées entre 2006 et 2014, ont mis au jour une soixantaine de sites, pour la plupart précédemment inconnus. Parmi les vestiges répertoriés se trouvent non seulement des sites funéraires protohistoriques, un vaste et riche site d'art rupestre attribuable à l'Âge du Bronze, des basreliefs et ruines de monuments bouddhiques mais aussi des vestiges fortifiés révélant des liens forts avec l'Asie Centrale.

\section{INDEX}

Mots-clés: Ladakh, archéologie, prospection, art rupestre, ruine, fortification, tombe, Bouddhisme, inscription, sculpture

Keywords: Ladakh, archaeology, survey, rock art, ruins, fortification, grave, Buddhism, inscription, carving

\section{AUTHORS}

\section{QUENTIN DEVERS}

Quentin Devers wrote a thesis on the fortifications of Ladakh. In the course of a series of extensive surveys he has adopted an approach of built archaeology, analyzing all built remains such as ruined settlements and ruined Buddhist monuments. An important component of his research is the study of sites in a spatial perspective, aiming at understanding ancient route networks and the evolution of territorial dynamics over time.

Publications : 
In press An Archaeological Account of Nyarma and its Surroundings, Ladakh, in C. Jahoda, C. Kalantari (eds.), Material on Western Tibet (Vienna, OAW).

2012 with Vernier, M. A Remarkable Chorten in Markha Village, Ladakh, Artibus Asiae, 72/2, pp. 443-451.

2011 with Vernier, M. An Archaeological Account of the Markha Valley, Ladakh, Revue d'Études Tibétaines, 10, pp. 61-113.

\section{LAURIANNE BRUNEAU}

Laurianne Bruneau specializes in the archaeology and the arts of South and Central Asia. Her researches aim at understanding the artistic and cultural relationships between these two regions. She is associate professor at the École Pratique des Hautes Études (EPHE) and affiliated to the team Tibet, Bhutan and Tibetan Cultural area of East Asian Civilizations Research Center (CRCAO) in Paris. Since 2012 Laurianne is the co-director of the Indo-French Archaeological mission in Ladakh in cooperation with the Archaeological Survey of India (ASI).

Publications :

sous presse Étude thématique et stylistique des pétroglyphes du Ladakh (Jammu \& Cachemire, Inde) : une nouvelle contribution à l'art rupestre d'Asie Centrale pour l'Âge du Bronze, Eurasia Antiqua, 18, pp. 1-19.

2013 with Bellezza, J.V. The Rock Art of Upper Tibet and Ladakh : Inner Asian cultural adaptation, regional differentiation and the Western Tibetan Plateau Style, Revue d'Études Tibétaines, 28, pp. 5-161.

2011 Influence of the Indian cultural area in Ladakh in the 1st millennium AD : the rock inscriptions evidence, Puratattva - The Bulletin of the Indian Archaeological Society, 41, pp. 179-190.

\section{MARTIN VERNIER}

Martin Vernier is an independent archaeologist and tibetologist based in Switzerland. Since 1996 he has focused on the historical and archaeological heritage of Ladakh. Laureate of a research grant, he spent two years (2003-2004) exploring and systematically documenting the petroglyphs of the region. He created the first electronic database and published the first monograph on Ladakhi rock art. He now conducts research on the stone Buddhist steles and reliefs. Publications :

2013 The Forgotten citadel of Stok mon mkhar, Revue d'Études Tibétaines, 27, pp. 81-102.

2012 with Devers, Q. A Remarkable Chorten in Markha Village, Ladakh, Artibus Asiae, 72/2, pp. 443-451

2007 Exploration et Documentation des pétroglyphes du Ladakh 1996-2006 (Como, Quaderni Fondation Carlo Leone and Mariena Montandon - NodoLibri). 